\title{
Eighth Annual Report to Congress
}

Fiscal Year 1994 Progress in Implementing Section 120 of the Comprehensive

Environmental

Response,

Compensation, and

Liability

Act
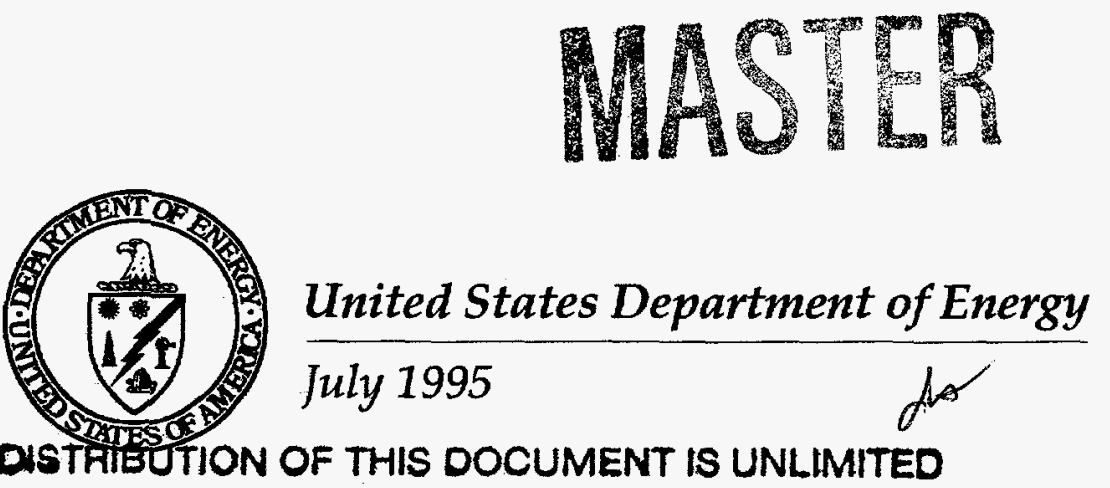


\section{DISCLAIMER}

Portions of this document may be illegible in electronic image products. Images are produced from the best available original document. 
TABLE OF CONTENTS

Page

EXECUTIVE SUMMARY

ES-1

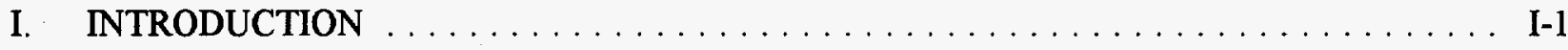

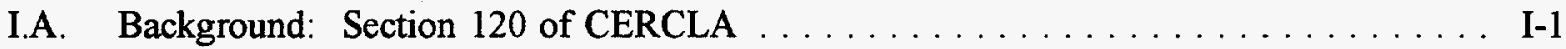

I.B. CERCLA Section 120(e)(5): Annual Report to Congress . . . . . . . . . . . . . I-2

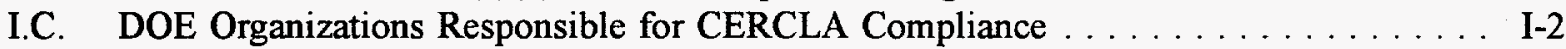

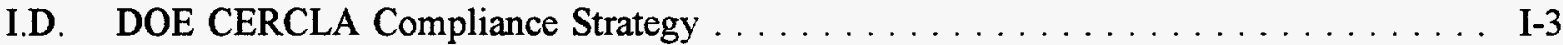

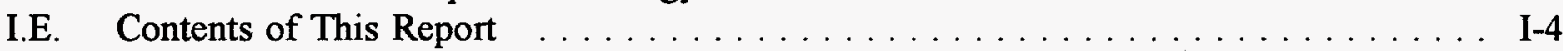

II. STATUS OF CERCLA ACTIVITIES AT DEPARTMENT OF ENERGY SITES $\ldots \ldots \ldots \ldots$ II-1

II.A. Progress in Reaching Interagency Agreements . . . . . . . . . . . . . II-1

II.B. Specific Cost Estimates and Budgetary Proposals to Support Environmental

Restoration Activities Required by the IAG . . . . . . . . . . . . . . II-1

II.C. Public Comments Regarding Proposed Interagency Agreements . . . . . . . . . . . . II-6

II.D. Instances in Which No Interagency Agreement Was Reached . . . . . . . . . . . II-6

II.E. Progress in Conducting Remedial Investigations/Feasibility

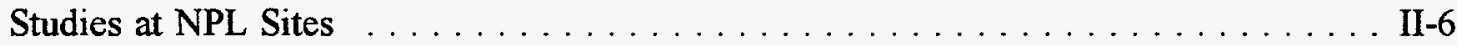

II.F. Progress in Conducting Remedial Actions at NPL Sites $\ldots \ldots \ldots \ldots \ldots \ldots \ldots$ II-8

II.G. Progress in Conducting Removal and Interim Actions at NPL Sites . . . . . . . . . . II-9

II.H. Progress in Performing Cleanup Activities at Facilities Not on the NPL . . . . . . . II-10

III. SITE SUMMARIES FOR FACILITIES ON THE NPL (BY STATE) $\ldots \ldots \ldots \ldots \ldots$ III-1

IV. SITE SUMMARIES FOR SELECTED FACILITIES NOT ON THE NPL (BY STATE) ... IV-1

V. STATUS OF ALL DOE FACILITIES/SITES SUBJECT TO SECTION 120

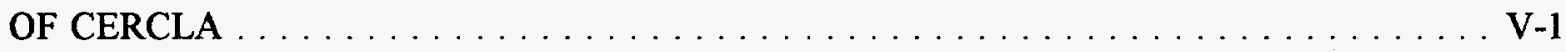

APPENDIX A List of Acronyms and Abbreviations $\ldots \ldots \ldots \ldots \ldots \ldots \ldots \ldots$

APPENDIX B Listing of Facilities $\ldots \ldots \ldots \ldots \ldots \ldots \ldots \ldots \ldots \ldots \ldots \ldots \ldots$ 


\section{LIST OF FIGURES}

Page

Figure II-1 Location of U.S. Department of Energy Facilities on the NPL . . . . . . . . II-4

Figure II-2 Location of Selected Facilities Not on the NPL Undergoing

Significant Cleanup Activities

\section{LIST OF TABLES}

Table ES-1 U.S. Department of Energy Facilities on the National Priorities List . . . . . . . ES-3

Table II-1 U.S. Department of Energy Facilities on the National Priorities List . . . . . . . II-2

Table III-1 Status of FEMP Removal Actions $\ldots \ldots \ldots \ldots \ldots \ldots \ldots \ldots$ III-35

Table V-1 Status of All DOE Facilities/Sites Listed on Docket Update \#8, Dated $11 / 10 / 93$ 
EXECUTIVE SUMMARY 


\section{EXECUTIVE SUMMARY}

\section{BACKGROUND}

Congress passed the Comprehensive Environmental Response, Compensation, and Liability Act (CERCLA) (Public Law 96-510), commonly known as Superfund, in 1980. The Superfund Amendments and Reauthorization Act (SARA) (Public Law 99-499), which amended CERCLA in 1986 , added Section 120 regarding the cleanup of contaminated sites at Federal facilities.

Under Section 120(e)(5) of CERCLA, each department, agency, or instrumentality of the Federal government responsible for compliance with Section 120 must submit an annual report to Congress concerning its progress in implementing the requirements of Section 120. The report must include information on the progress in reaching Interagency Agreements (IAGs), conducting Remedial Investigation and Feasibility Studies (RI/FSs), and performing remedial actions. Federal agencies that own or operate facilities on the National Priorities List (NPL) are required to begin an RI/FS for these facilities within 6 months after being placed on the NPL. Remediation of these facilities is addressed in an IAG between the Federal agency, the U.S. Environmental Protection Agency (EPA), and in some instances the state within which the facility is located.

This report, prepared by the U.S. Department of Energy's (DOE's) Office of Environmental Management, is being submitted to Congress in accordance with Section 120(e)(5) of CERCLA. It is DOE's Eighth Annual Report to Congress and provides information on DOE's progress in implementing CERCLA Section 120 in Fiscal Year 1994 (FY 94), i.e., from October 1, 1993, to September 30, 1994. In this report the words "site" and "facility" are used interchangeably.

\section{CURRENT STATUS}

There are currently 23 DOE sites on the NPL. These sites are presented by state on Table ES-1. Table ES-1 also includes information relating to when each site was placed on the NPL and the status of the IAG for the site. Three facilities were placed on the NPL in FY 94 and have not yet entered into IAGs. The other 20 facilities are conducting remedial activities as specified in their IAGs. DOE is also conducting remedial activities at 71 sites that are not on the NPL.

\section{REPORT CONTENTS AND ORGANIZATION}

This report provides the status of ongoing activities being performed in support of CERCLA Section 120 at DOE facilities. This includes activities conducted to reach IAGs and progress in conducting remedial actions.

Section I describes Section 120 of CERCLA, the requirements of the Annual Report to Congress, DOE organizations responsible for CERCLA compliance, and the DOE CERCLA compliance strategy.

Section II provides highlights on the status of CERCLA activities at DOE facilities, including progress in reaching IAGs, public comments regarding proposed IAGs, instances in which no IAG was reached, progress in conducting Remedial Investigations/Feasibility Studies at NPL sites, and progress in conducting remedial actions at NPL sites.

Section III provides site summaries for those facilities listed on the NPL (by state). These summaries provide detailed information as specified by Section 120(e)(5) of CERCLA. 
Section IV provides site summaries for selected sites not listed on the NPL (by state). Although this section is not required by CERCLA, it is provided for public information, as these sites are conducting significant remediation activities.

Section $\mathrm{V}$ provides an overview (by state) of all of the cleanup activities required by CERCLA Section 120 occurring at DOE facilities.

Appendix A provides a list of acronyms and abbreviations used in this report. Appendix B is an alphabetical listing of the facilities discussed in this report by facility name, showing the pages in the report on which their primary information is discussed. 
Table ES-1. U.S. Department of Energy Facilities on the National Priorities List

\begin{tabular}{|c|c|c|c|}
\hline STATE & SITE NAME & $\begin{array}{l}\text { DATE OF FR }{ }^{1} \text { NOTICE } \\
\text { OF NPL LISTING }\end{array}$ & INTERAGENCY AGREEMENT (IAG) STATUS \\
\hline \multirow[t]{3}{*}{ California } & $\begin{array}{l}\text { Laboratory for Energy-Health } \\
\text { Research (LEHR) }\end{array}$ & $05 / 31 / 94$ & $\begin{array}{l}\text { Memorandum of Agreement with University of California, Davis, } \\
\text { signed in 1989; Federal Facility Agreement under development. }\end{array}$ \\
\hline & $\begin{array}{l}\text { Lawrence Livermore National } \\
\text { Laboratory - Main Site } \\
\end{array}$ & $07 / 22 / 87$ & Federal Facility Agreement executed on November 1, 1988. \\
\hline & $\begin{array}{l}\text { Lawrence Livermore National } \\
\text { Laboratory - Site } 300\end{array}$ & $08 / 30 / 90$ & Federal Facility Agreement signed on June 29, 1992. \\
\hline Colorado & $\begin{array}{l}\text { Rocky Flats Environmental } \\
\text { Technology Site (formerly the Rocky } \\
\text { Flats Plant) }\end{array}$ & $10 / 04 / 89$ & IAG executed on January 22,1991 ; currently under renegotiation. \\
\hline Idaho & $\begin{array}{l}\text { Idaho National Engineering } \\
\text { Laboratory (includes Argonne } \\
\text { National Laboratory - West) }\end{array}$ & $11 / 21 / 89$ & $\begin{array}{l}\text { Federal Facility Agreement/Consent Order executed on } \\
\text { December 9, 1991. }\end{array}$ \\
\hline Kentucky & Paducah Gaseous Diffusion Plant & $05 / 31 / 94$ & IAG under negotiation. \\
\hline \multirow[t]{2}{*}{ Missouri } & $\begin{array}{l}\text { St. Louis Site (includes St. Louis } \\
\text { Airport Site and Vicinity Properties, } \\
\text { Latty Avenue Properties) }\end{array}$ & $10 / 04 / 89$ & Federal Facility Agreement signed on June 26, 1990. \\
\hline & $\begin{array}{l}\text { Weldon Spring Site Remedial Action } \\
\text { Project (formerly referred to as } \\
\text { Weldon Spring Quarry and Feed } \\
\text { Materials Plant and Raffinate Pits } \\
\text { Site) }\end{array}$ & $\begin{array}{l}07 / 22 / 87 \\
03 / 13 / 89^{3}\end{array}$ & $\begin{array}{l}\text { Federal Facility Agreement signed on August 22, 1986; amended } \\
\text { June 30, 1992; currently under renegotiation to include State of } \\
\text { Missouri as a party. }\end{array}$ \\
\hline \multirow[t]{2}{*}{ New Jersey } & Maywood Site $^{2}$ & $09 / 08 / 83$ & $\begin{array}{l}\text { Federal Facility Agreement signed on July 23, 1990, and made } \\
\text { effective in April 1991. }\end{array}$ \\
\hline & Wayne Site $^{2}$ & $09 / 21 / 84$ & $\begin{array}{l}\text { Federal Facility Agreement signed on July 23, 1990, and made } \\
\text { effective in April } 1991 .\end{array}$ \\
\hline New York & Brookhaven National Laboratory & $11 / 21 / 89$ & IAG executed on February 28, 1992, effective May 27, 1992. \\
\hline
\end{tabular}


Table ES-1. U.S. Department of Energy Facilities on the National Priorities List (Continued)

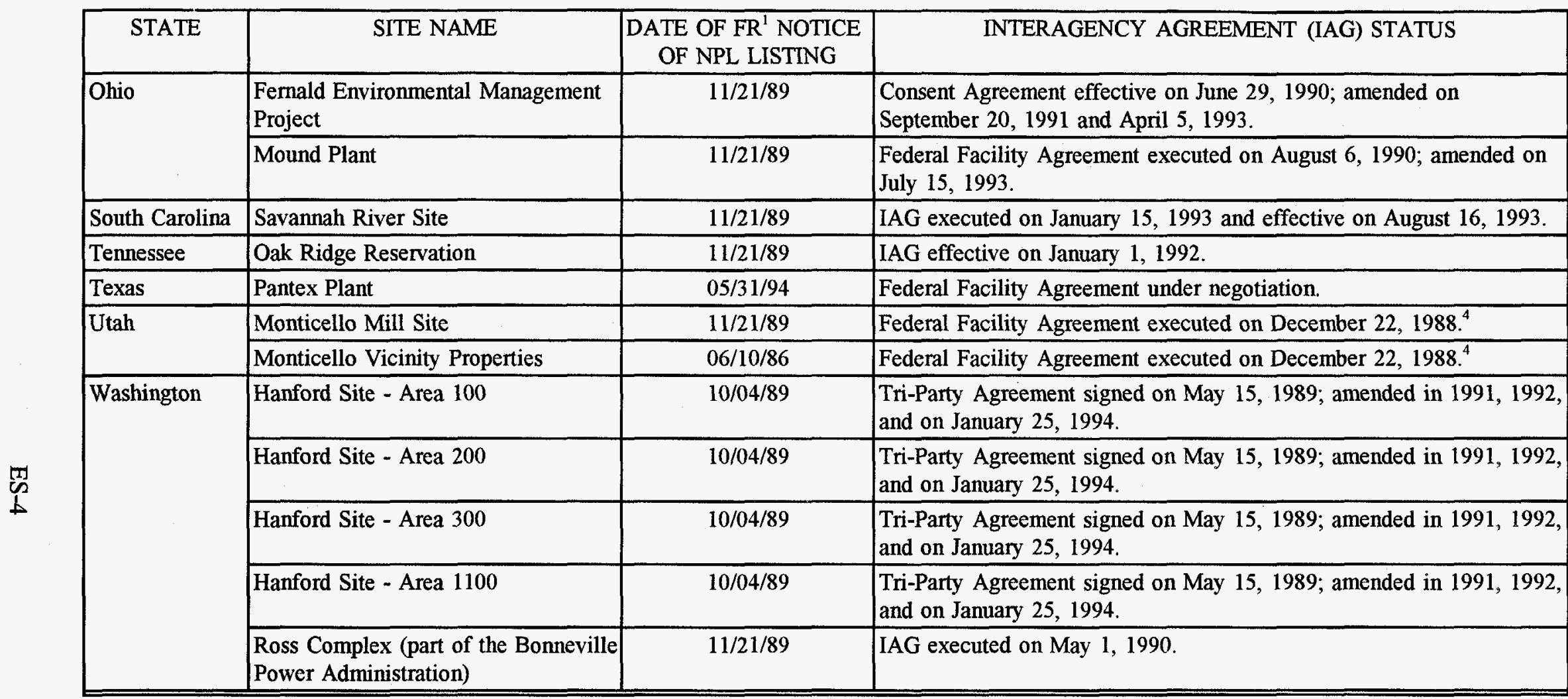

FR $=$ Federal Register

2 Congress directed DOE to remediate these sites. The states (New Jersey and Missouri) are not parties to these IAGs.

3 The Feed Materials Plant and Raffinate Pits were added to the site 3/13/89.

4 One IAG was executed for both Monticello sites, although the sites are listed separately on the NPL. 
SECTION I

INTRODUCTION 


\section{INTRODUCTION}

\section{I.A. Background: Section 120 of CERCLA}

Congress passed the Comprehensive Environmental Response, Compensation, and Liability Act (CERCLA) (Public Law 96-510), commonly known as Superfund, in 1980. The primary goal of the Act is to encourage the identification and remediation of sites contaminated with hazardous substances.

The Superfund Amendments and Reauthorization Act (SARA) (Public Law 99-499), which amended CERCLA in 1986, added certain specific provisions applicable to the cleanup of contaminated sites at Federal facilities. These provisions, located in Section 120 of CERCLA, are briefly described below.

Under Section 120(a)(1), CERCLA specifies that Federal departments, agencies, and instrumentalities must comply with CERCLA in the same manner and to the same extent as nongovernmental entities. Except for requirements applicable to bonding, insurance, or financial responsibility, all guidelines, rules, regulations and criteria applicable to preliminary assessments (PAs), National Contingency Plan (NCP) evaluations, inclusion on the National Priorities List (NPL), and the conduct of remedial action are applicable to contaminated sites at Federal facilities (Sections 120(a)(2),(3),(4)).

Even before the passage of SARA, Federal agencies were required to identify sites where hazardous waste was treated, stored, or disposed of at any time under both CERCLA (Section 103(c)) and the Resource Conservation and Recovery Act (RCRA) (Section 3016). SARA added Section 120(b), which requires Federal agencies to also identify contamination affecting contiguous or adjacent property and any monitoring data associated with this contamination.

Section 120(c) of CERCLA requires the U.S. Environmental Protection Agency (EPA) to compile information about contaminated sites at Federal facilities and enter it into the Federal Agency Hazardous Waste Compliance Docket (the docket). The docket must include information about Federal facilities where hazardous wastes are generated and managed under Sections 3010 and 3005 of RCRA, respectively. The docket also must be made available to the public and updated every 6 months to include new facilities and additional information about facilities that were already on the list.

Section 120(d) of CERCLA requires Federal agencies to conduct a PA of facilities listed on the docket within 18 months after docket listing. If the PA indicates a need for further investigation, the responsible agency must conduct a site investigation (SI). Based on information developed in the PA or PA/SI, EPA must determine if 1) no further remedial action is necessary at this time, or 2) further evaluation and possible inclusion on the NPL are warranted.

Section 120(e) of CERCLA requires Federal agencies that own or operate facilities on the NPL to begin a remedial investigation and feasibility study (RI/FS) for these facilities not later than 6 months after being placed on the NPL. EPA must review the results of each Federal facility RI/FS. Within 180 days after the completion of EPA's review, Federal agencies must enter into interagency agreements (IAGs) with EPA for expeditious completion of remedial action at the facility. The contents of IAGs must include:

- A review of alternative remedial actions and selection of a remedial action,

- A schedule for the completion of the remedial action, and

- Arrangements for long-term operation and maintenance of the facility. 
Remedial action must begin not later than 15 months after the completion of a RI/FS and must be completed "as expeditiously as practicable." To ensure that adequate funds are appropriated to perform cleanup, Federal agencies must include a statement of the hazards posed to human health, welfare, and the environment by each facility on the NPL. Also, specific consequences of failure to begin and complete remedial action must be identified and included in annual budget submissions to Congress.

\section{I.B. CERCLA Section 120(e)(5): Annual Report to Congress}

Under Section 120(e)(5) of CERCLA, each department, agency, or instrumentality of the Federal government responsible for compliance with Section 120 must submit an annual report to Congress concerning its progress in implementing the requirements of Section 120 . The report must include information on at least the following items:

- $\quad$ Progress in reaching IAGs under CERCLA Section 120,

- Specific cost estimates and budgetary proposals involved in each IAG,

- A brief summary of the public comments regarding each proposed IAG,

- A description of the instances in which no IAG was reached,

- $\quad$ Progress in conducting RI/FSs,

- Progress in conducting remedial actions,

- Progress in conducting remedial actions at facilities which are not on the NPL,

- An explanation of any failure to conclude an IAG within 180 days after EPA review, and

- $\quad$ A detailed description on a state-by-state basis of the status of each facility subject to CERCLA Section 120, including a description of the hazards presented by each facility, plans and schedules for initiating and completing response actions, enforcement status (where appropriate), and an explanation of any postponements or failure to complete response actions.

This report is being submitted to Congress in accordance with Section 120(e)(5) of CERCLA. It is the U.S. Department of Energy's (DOE) Eighth Annual Report to Congress under Section 120(e)(5) and provides information on DOE's progress in implementing CERCLA Section 120 in Fiscal Year 1994 (FY 94), i.e., from October 1, 1993, to September 30, 1994.

\section{I.C DOE Organizations Responsible for CERCLA Compliance}

This report was prepared by DOE's Office of Environmental Restoration (EM-40) within the Office of Environmental Management (EM). EM was created in 1989 to consolidate responsibility within DOE for environmental management activities. EM is responsible for developing DOE policies and plans related to environmental restoration and waste management. Functions within EM include 1) ensuring worker safety and health, 2) managing and planning budgets, 3) monitoring legal and compliance issues, 4) implementing public participation programs, 5) safely transporting all DOE materials, and 6) minimizing waste generated. 
Within the EM organization, the following offices play an important role in CERCLA compliance activities.

- The Office of Waste Management (EM-30) is responsible for the treatment, storage, and disposal of wastes generated by environmental restoration activities.

- The Office of Environmental Restoration (EM-40) is responsible for the cleanup of contamination at DOE sites.

- The Office of Technology Development (EM-50) is responsible for the development of new and more effective technologies to address contamination and management of wastes at DOE sites.

- The Office of Nuclear Material and Facility Stabilization (EM-60) is responsible for the safe transition of contaminated facilities to the EM organization.

The EM organization is assisted in CERCLA compliance activities by the Office of Policy and Assistance (EH-41) within DOE's Office of Environment, Safety and Health (EH). The mission of the EH-41 organization is to 1) develop Department-wide environmental protection policies and complexwide strategies for protecting the public and the environment and for attaining and maintaining environmental compliance with internal and external environmental requirements, and 2) assist program and field offices in averting environmental compliance problems.

\section{I.D. DOE CERCLA Compliance Strategy}

Compliance with environmental laws, regulations, and internal requirements is central to the operation of DOE facilities. The fundamental goal of environmental compliance is to ensure that risks to human health and the environment posed by DOE's past, present, and future operations are either eliminated or reduced to prescribed, safe levels.

As a result of almost 50 years of weapons development and energy research, DOE faces an enormous task in characterizing and remediating numerous facilities across the country. This task is complicated by the nature of the activities associated with ensuring that each remedial action complies with Federal, state, Native American and local regulations. These complex legal processes contribute to the difficulties faced by DOE. Other complicating factors include multiple contaminants, contaminants that are unidentified because of incomplete historical records or lack of characterization data, and lack of proven technologies. DOE is committed to addressing these concerns as quickly, safely, and efficiently as possible.

DOE's remediation activities are governed by CERCLA, RCRA, the National Environmental Policy Act (NEPA), and other applicable laws. CERCLA addresses the uncontrolled releases of substances to the environment and the cleanup of inactive waste sites. RCRA addresses the management of regulated hazardous waste and requires that permits be obtained for DOE facilities that treat, store, or dispose of hazardous or mixed waste. RCRA also requires corrective action to address releases of hazardous contaminants. NEPA requires that Federal agencies consider the environmental effects of major Federal actions significantly affecting the human environment in the decisionmaking process. It is the Department's policy to rely on the CERCLA process for review of actions to be taken under CERCLA and to incorporate, to the extent practicable, NEPA values such as analysis of cumulative, off-site, ecological, and socioeconomic impacts into CERCLA documentation. The Department may, 
however, after consulting with its stakeholders and as a matter of policy, integrate the CERCLA and NEPA processes for specific proposed actions. It is also part of the Department's policy to take steps to ensure opportunities for early public involvement in the CERCLA process.

\section{I.E Contents of This Report}

This report presents information on contaminated sites at DOE facilities that were placed on the NPL as of May 31, 1994, and on facilities on the docket as of November 10, 1993 (Docket Number 8). These versions of the NPL and docket were the last versions of these documents published before FY 94 ended. Information on DOE sites and facilities placed on the NPL or docket after FY 94 ended will be included in subsequent CERCLA reports to Congress. In this section of the report and in subsequent sections, the words "site" and "facility" are used interchangeably.

This report does not contain information on DOE remedial activities at sites that have not been placed on the docket and thus are not subject to the requirements of Section 120 of CERCLA. These sites may include 1) NPL sites that are not owned by DOE (such as the Maxey Flats Disposal Site in Kentucky, where DOE has been named as a Potentially Responsible Party), 2) Uranium Mill Tailings Remedial Action (UMTRA) project sites, 3) sites in the Formerly Utilized Sites Remedial Action Program (FUSRAP), and 4) non-DOE sites that became contaminated as a result of nuclear research and development activities sponsored by DOE and its precursors.

Section II provides a discussion of DOE's overall progress in reaching IAGs and responding to public comments regarding proposed IAGs. It also identifies instances where no IAG has been concluded. Section II further provides highlights on progress in conducting RI/FSs, remedial actions, and response activities at NPL sites, and in performing cleanup activities at sites not on the NPL.

Section III provides a detailed description of the status of each NPL facility subject to CERCLA Section 120 on a state-by-state basis. Included in this section is a description of the hazards presented, plans and schedules for initiating and completing response actions, enforcement status (where appropriate), and an explanation of any postponements or failure to complete response action. This section identifies DOE's FY 94 funding, appropriated FY 95 funding, and funding requested in the President's Budget for FY 96 for environmental restoration at each NPL facility.

Section IV provides a description of the remediation status of non-NPL facilities (by state) subject to CERCLA Section 120 where significant remediation activities are occurring. The facilities presented in this section are on the docket. This section identifies FY 94 funding and FY 95 and FY 96 budgetary proposals for environmental restoration at these non-NPL facilities.

Section V provides an overview of all CERCLA Section 120 activities occurring at facilities listed on the docket for which DOE is responsible on a state-by-state basis. It includes summary information on the NPL facilities featured in Section III, the non-NPL facilities featured in Section IV, and all of the other DOE facilities included on the docket.

Appendix A is a list of the acronyms and abbreviations used in this report.

Appendix B is an alphabetical listing of the facilities discussed in this report by facility name showing the pages in the report on which their primary information is discussed. 
SECTION II

STATUS OF CERCLA ACTIVITIES AT

DEPARTMENT OF ENERGY SITES 


\section{STATUS OF CERCLA ACTIVITIES AT DEPARTMENT OF ENERGY SITES}

This section of the report provides information on: the U.S. Department of Energy's (DOE) progress in reaching interagency agreements (IAGs); public comments regarding proposed IAGs; instances in which no IAG was reached; progress in conducting Remedial Investigation/Feasibility Studies (RI/FSs); progress in conducting remedial actions and response activities at National Priorities List (NPL) sites; and progress in conducting remedial action at non-NPL sites.

\section{Identification of NPL and Non-NPL Sites}

There are currently 23 DOE sites on the NPL. These sites are presented by state on Table II-1. Table II-1 also includes information relating to when each site was placed on the NPL and the status of the IAG for the site. Figure II-1 shows the location of these facilities. The Hanford Site is presented as one site on the figure; however, four sites (Areas 100, 200, 300 and 1100) are listed separately on the NPL.

As shown on Table II-1, three of the 23 sites (Laboratory for Energy-Health Research, CA; Paducah Gaseous Diffusion Plant, KY; and Pantex Plant, TX) were added to the NPL during Fiscal Year 1994 (FY 94).

Figure II-2 shows the location of the non-NPL facilities featured in Section IV of this report.

\section{II.A. Progress in Reaching Interagency Agreements}

The Comprehensive Environmental Response, Compensation, and Liability Act (CERCLA) Section $120(e)(2)$ requires that within 180 days after EPA's review of an RJ/FS, the Federal facility must enter into an IAG (i.e., an agreement between DOE and EPA) for the expeditious completion of all necessary remedial action. It is DOE policy, however, to enter into IAGs addressing both the RI/FS and the implementation of remedial action before the RI/FS is completed. IAGs are revised as necessary to incorporate new information, adjust schedules, and address changing conditions.

IAGs are known by different names at different sites. DOE has entered into the following types of IAGs addressing CERCLA remediation: Federal Facility Agreements, Federal Facility Consent Agreements, and a Tri-Party Agreement. The names of the IAGs used by the site are those cited in this report.

As shown on Table II-1, DOE has entered into IAGs at 20 of the 23 facilities on the NPL.

DOE has not experienced any failure to conclude an IAG within 180 days after EPA review of an RI/FS. Consequently, there is no need for this report to contain an explanation of failure to reach an IAG within the allotted time period.

\section{B Specific Cost Estimates and Budgetary Proposals to Support Environmental Restoration Activities Required by the IAG}

The site summaries presented in Sections III and IV contain dollar amounts that support the environmental restoration activities that are being performed pursuant to CERCLA as specified in IAGs. Consequently, these dollar amounts do not represent the entire environmental restoration budget for the site. 
Table II-1. U.S. Department of Energy Facilities on the National Priorities List

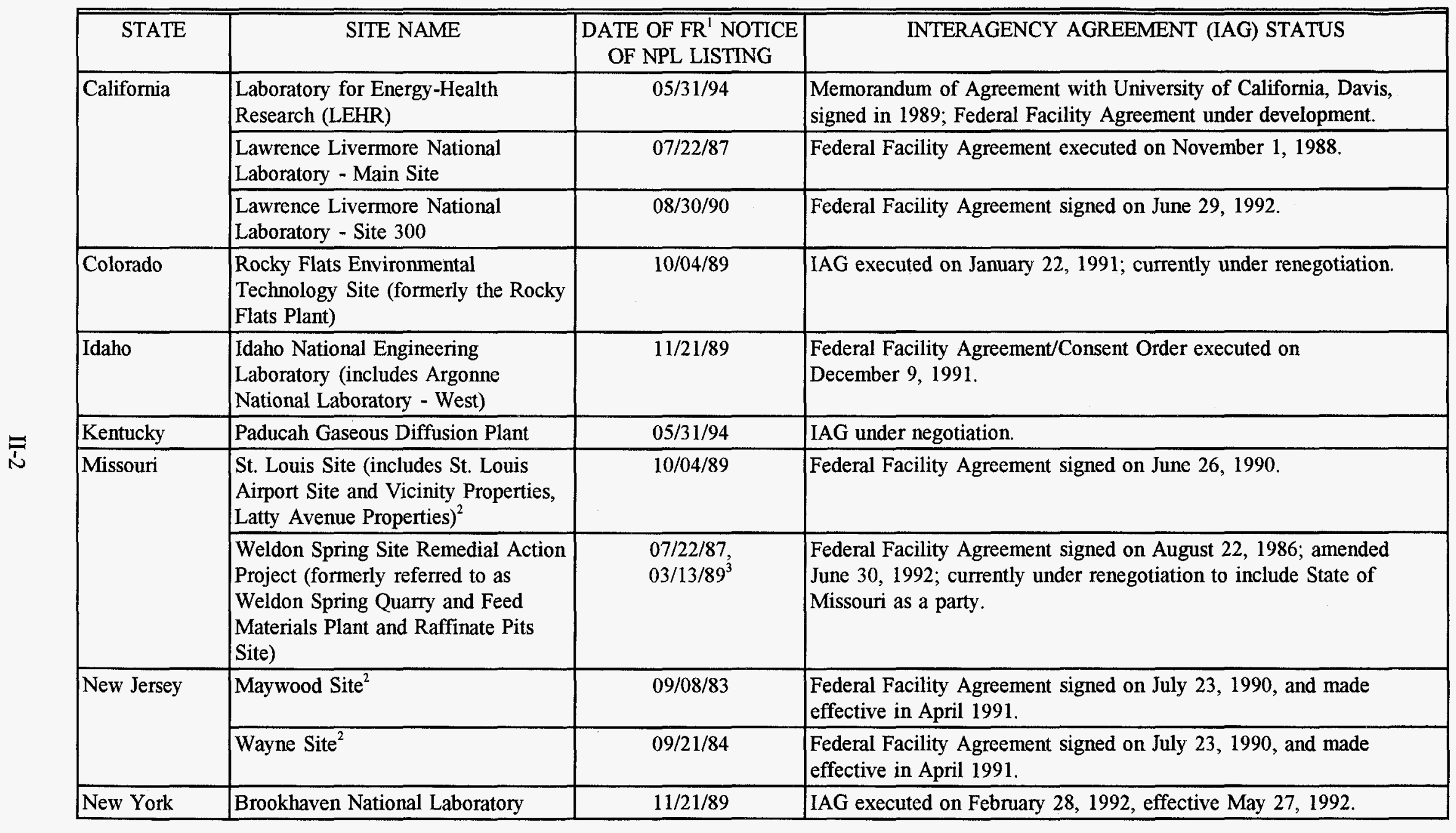


Table II-1. U.S. Department of Energy Facilities on the National Priorities List (Continued)

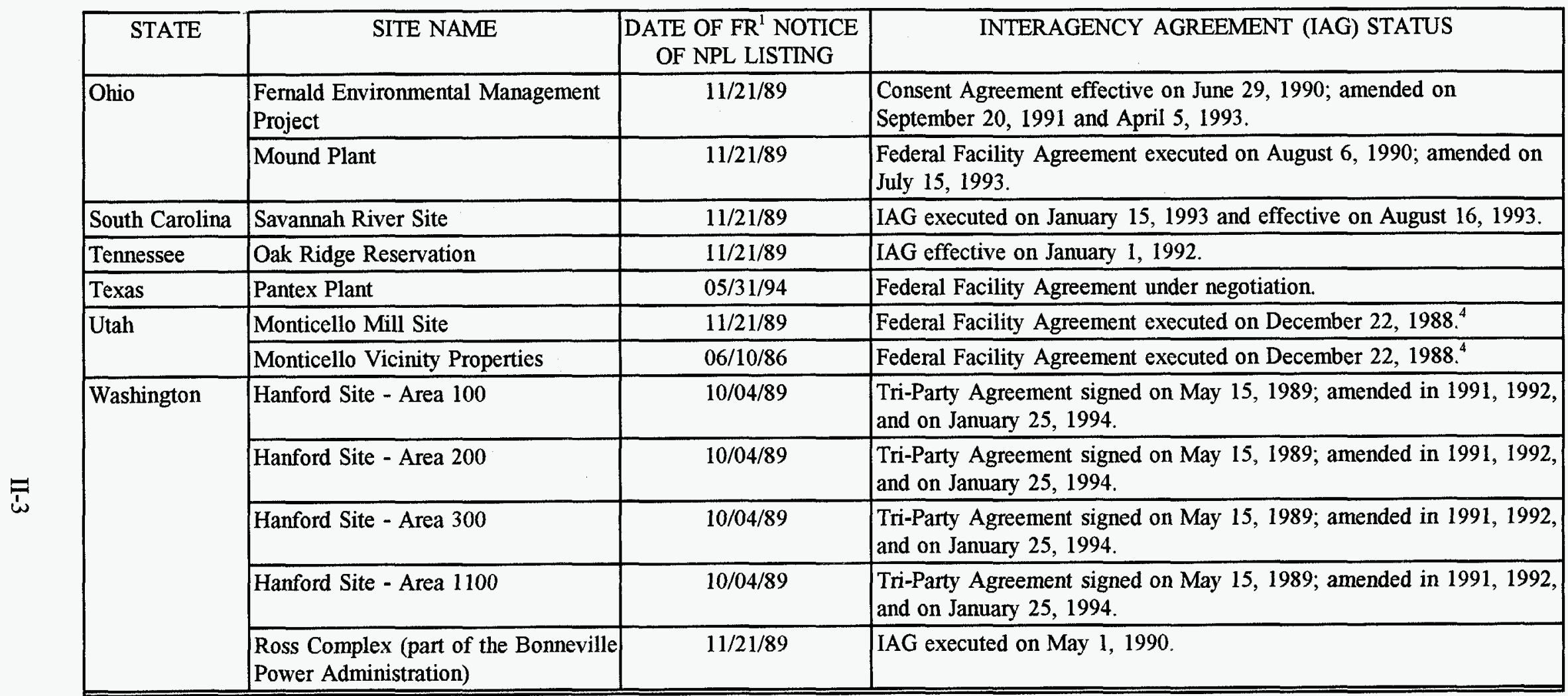

FR = Federal Register

Congress directed DOE to remediate these sites. The states (New Jersey and Missouri) are not parties to these IAGs.

3 The Feed Materials Plant and Raffinate Pits were added to the site 3/13/89.

4 One IAG was developed for both Monticello sites, but the sites are listed separately on the NPL. 
Figure II-1. Location of U.S. Department of Energy Facilities on the NPL

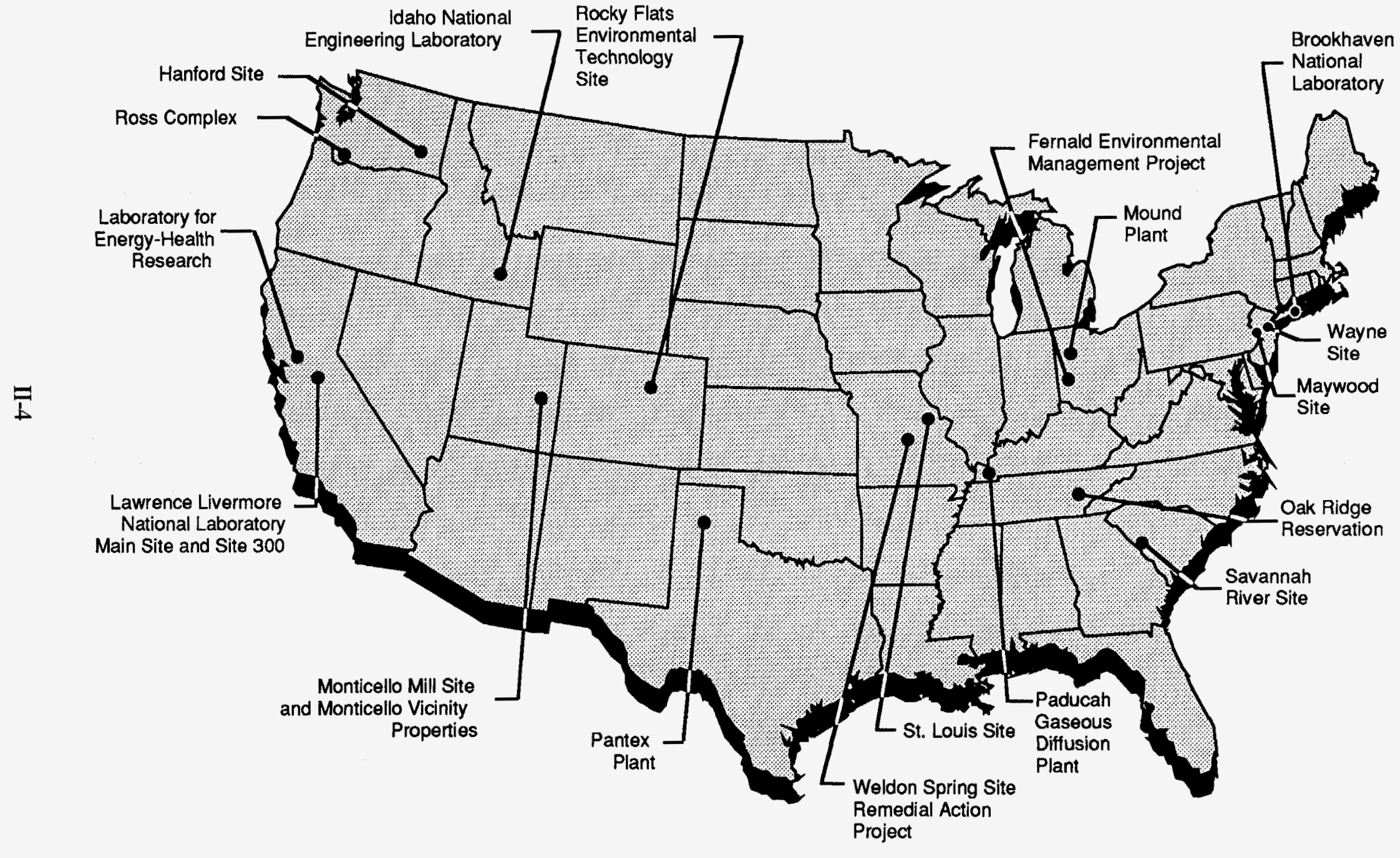


Figure II-2. Location of Selected Facilities Not on the NPL Undergoing Significant Cleanup Activities

疋

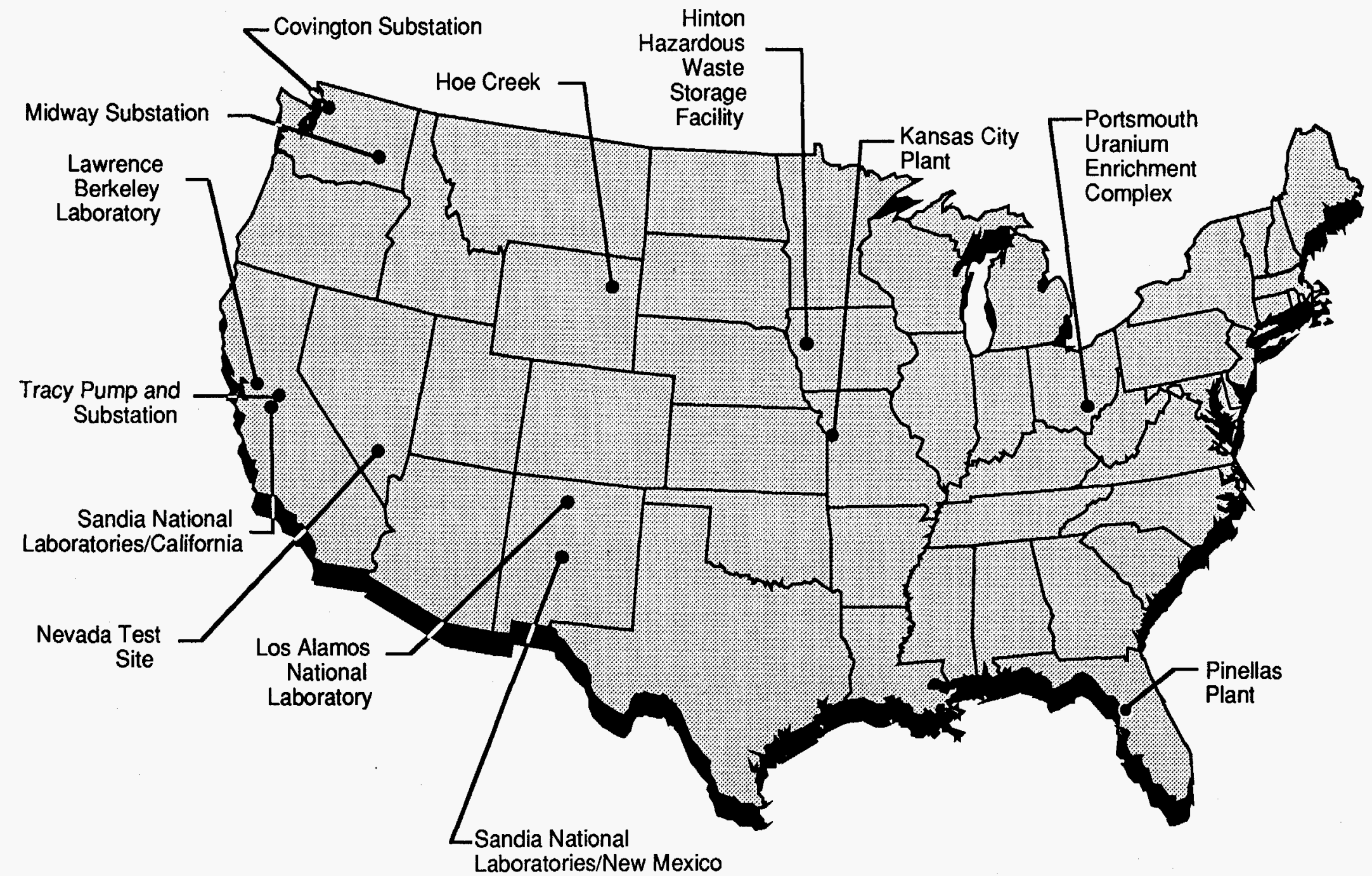


The FY 94 amount in each summary box represents actual dollars spent in FY 94. The FY 95 dollars is the appropriated funding and the FY 96 is the request in the President's Budget. These budget figures do not, however, reflect the rescission that occurred in FY 95.

\section{II.C. Public Comments Regarding Proposed Interagency Agreements}

During FY 94, no new IAGs were proposed. Consequently, there were no public comments regarding proposed IAGs.

The Hanford Tri-Party Agreement was renegotiated between July and September 1994. A 45-day public comment period, including public meetings, starts in FY 95. Public comments regarding the renegotiated agreement will be discussed in next year's CERCLA 120 report.

Discussions began in FY 93 between DOE and regulatory agencies regarding amendments to the current IAG at the Rocky Flats Environmental Technology Site. The public has been kept abreast of this activity, and a preliminary draft of the amended IAG was made available for informal public comment. Public comment occurred in FY 94.

\section{II.D. Instances in Which No Interagency Agreement Was Reached}

The three NPL sites where DOE has not yet entered into IAGs - the Laboratory for Energy-Health Research (LEHR), CA; Paducah Gaseous Diffusion Plant, KY; and Pantex Plant, TX-were placed on the NPL in FY 94. DOE expects to sign IAGs for these facilities before the RU/FSs for these facilities are completed.

\section{II.E. Progress in Conducting Remedial Investigations/Feasibility Studies at NPL Sites}

CERCLA Section 120(e)(1) specifies that RI/FS work must be initiated within 6 months after a site is listed on the NPL. RI/FS work was initiated within this statutory time frame at all 23 DOE facilities on the NPL.

Highlights of FY 94 RI/FS accomplishments are listed below.

Brookhaven National Laboratory - RI/FS activities are under way at three of the five operable units (OUs), including the submittal of one Remedial Investigation (RI) Report and one Risk Assessment Report. Two draft work plans were also submitted and approved.

Fernald Environmental Management Project - Four RI plans and three Feasibility Study/Proposed Plan (FS/PPs) were submitted. Two RI plans, one FS/PP, and one Interim Record of Decision (Interim ROD) were approved. One FS/PP was conditionally approved.

Hanford Site (Areas 100, 200, 300 and 1100) - Three Work Plans, three Proposed Plans, three Focused Feasibility Study (FS) Reports, one Phase 3 FS Report, one Phase 2 RI Report, and six limited Field Investigation Reports were submitted.

Idaho National Engineering Laboratory - RI/FS activities are complete or under way at all of the ten waste area groups (WAGs). 
Lawrence Livermore National Laboratory - Site 300 - A draft of the Site Wide Remedial Investigation Report was submitted on March 10, 1994 in accordance with the revised RI schedule. A draft FS for OU 1 was prepared in November 1993. Draft and Final FSs for OU 2 were prepared and submitted in FY 94. The draft FS for OU 3 was also submitted in FY 94.

Maywood Site - A Final Draft FS Report was issued in April 1994. A Proposed Plan was developed and will be released for public comment in FY 95.

Monticello Mill Site and Monticello Vicinity Properties -The baseline surface water and groundwater sampling for the Mill Site OU 3 RI was completed, and the Baseline Data Summary Report was prepared. The Draft Final RI/FS work plan for OU 3 was submitted in July 1994.

Mound Plant - RI/FS activities are under way at four OUs (OU 1, OU 2, OU 5, and OU 9). Field work for OU 1 was completed; the RI report was submitted in November 1993. The OU 2 RI field work for Phase I sampling was completed. The OU 5 RI field work for Phase I sampling was completed. Verification of soil sites cleaned under the Mound decommissioning program continued at OU 6. Assessment activities continued at OU 9.

Oak Ridge Reservation - Submittal of one Draft RI Report, one RI Work Plan/SI Report, three RI/FS Reports, one Site Characterization Work Plan, three Treatability Study Work Plans, four Proposed Plans; three RI reports, two FS Reports, one ROD, and two Post-Construction Reports; approval of two Interim RODs; submittal and approval of one Engineering Evaluation/Cost Analysis and a plan to separate Clinch River and Watts Bar OU into two separate remedial actions to streamline the remediation process.

Rocky Flats Environmental Technology Site - An ROD was completed and approved by regulatory agencies. RI work plans for 15 OUs have been approved by regulatory agencies. RI field work is complete at eight OUs and is under way at the remaining seven. One Final and two Draft RI reports were submitted to regulatory agencies, and $\mathrm{RI}$ reports are underway for the other five OUs where field work has been completed. FSs have been started for four OUs. The FS report for OU 1 was submitted. The Phase II RCRA Facility Investigation/Remedial Investigation (RFI/RI) work plan for OU 4 was completed and approved.

Savannah River Site - Two RFI/RI Plans, two Baseline Risk Assessments, eight Proposed Plans, and 24 Site Evaluation Reports were submitted. Two Final Remedial RODs were signed.

St. Louis Site - One FS was completed and submitted to EPA and the State of Missouri for review.

Wayne Site - An RI Report was issued in October 1993. An FS Report (EPA Final Draft) was issued in March 1994. A Proposed Plan was developed and will be released for public comment in FY 95.

Weldon Spring Site Remedial Action Project - A Remedial Design Work Plan (Conceptual Design Report) and a Remedial Action Work Plan were completed. 


\section{II.F. Progress in Conducting Remedial Actions at NPL Sites}

CERCLA Section 120(e)(2) requires that substantial, continuous, physical, onsite remedial action commence at each facility not later than 15 months after completion of the RI/FS. During FY 94, several sites made significant progress in their remedial actions. Highlights of some of these activities are listed below.

Hanford Site (Areas 100, 200, 300, and 1100) - Cleanup was completed at the North Slope and the Arid Lands Ecology Reserve, a major accomplishment in the cleanup of Hanford. After regulators approve the final cleanup reports, approximately 46 percent of the site will be made available for other uses.

Idaho National Engineering Laboratory - Thirty No Further Action determinations were approved as outlined in the Federal Facility Agreement/Consent Order.

Lawrence Livermore National Laboratory - Main Site - Two of the groundwater treatment facilities called for under the June 1992 ROD were constructed and began operations. Final Remedial Design Report No. 3 was completed and issued. Both the Draft and Final Remedial Design Report No. 6 were submitted.

Lawrence Livermore National Laboratory - Site 300 - Two interim groundwater treatment facilities continued operations.

Mound Site - Three removal actions were initiated. One underground line was removed. A 30-acre parcel was declared clean and proposed for transfer for economic development. Three of nine OUs were closed.

Monticello Mill Site and Monticello Vicinity Properties -At the Mill Site OU 1, construction of the staging area, including decontamination facilities, haul roads, and the runoff retention pond, was completed; installation of surface water drainage control structures is near completion. At the Mill Site OU 2, remedial action began on four peripheral properties and was completed on three properties in FY 94; remedial actions were completed for 62 vicinity properties in FY 94. Remedial actions on 305 vicinity properties out of a project total of 410 properties have been completed through FY 94 .

Oak Ridge Reservation - Two Interim ROD cleanup activities were completed.

Rocky Flats Environmental Technology Site - During FY 94, sludge removal commenced at the OU 4 solar ponds. By the end of the fiscal year, operations were proceeding in the last pond that contained water and sludge. Sludge removal operations will be completed in early FY 95.

Ross Complex - Cleanup of the Capacitor Test Lab initiated in January 1994 is now complete. - Installation of a multilayer cap over the Fog Chamber Dump began in FY 94 and is expected to be complete in FY 95. Contaminated soil from the Wood Pole Storage Yard was excavated in the summer of 1994 and is now being treated onsite utilizing enhanced bioremediation. Removal of polychlorinated biphenyl (PCB) contaminated soil from the Ross Substation was accomplished in January 1994 leaving only the capacitor yard cleanup for the summer of 1995 when PCB equipment is scheduled for replacement. This PCB removal is the last of the remediation activities included in the RODs. 
Savannah River Site - Seven Remedial Actions were completed.

Wayne Site - All remaining vicinity properties were remediated.

\section{II.G Progress in Conducting Removal and Interim Actions at NPL Sites}

Response actions other than remedial action activities were taken during FY 94. These actions were primarily removal or interim actions designed to provide prompt or immediate response to actual or potential threats of a release of hazardous substances to the environment. Highlights of some of these activities are listed below.

Brookhaven National Laboratory - Six major removal actions are planned or are under way. One Soil Removal Action (Building 464) was completed in FY 94. In addition, a Draft Completion Report for an Underground Storage Tank removal was completed, a Draft Engineering Evaluation/Cost Analysis for the Landfills Removal Action was submitted, and Draft Designs for the Cesspool Removal Action were submitted.

Fernald Environmental Management Project - Six removal actions were completed in FY 94. An additional 13 removal actions have been planned or are under way.

Hanford Site (Areas 100, 200, 300, and 1100) - An Engineering Evaluation/Cost Analysis for the expedited construction of a barrier wall and the start of a pump and treat system at N-Springs was completed. In addition, the carbon tetrachloride vapor extraction system at $200-\mathrm{ZP}-2$ is now automated.

Idaho National Engineering Laboratory - Two removal actions were completed in FY 94. Activities are continuing on five other removal actions. Two interim actions were completed and activities continued on three other interim actions.

Maywood Site - Subcontracts were awarded to begin removal of the Maywood Interim Storage Site Pile. Removal operations will begin in FY 95.

Oak Ridge Reservation - One Interim Action, one Interim Removal, and three Removal Actions were completed.

Rocky Flats Environmental Technology Site - A groundwater collection and treatment interim remedial action (IRA) facility at OU 1 and a surface water collection and treatment IRA at OU 2 continued operation throughout FY 94. Work continued in FY 94 on Option B Offsite Water Projects to replace the drinking-water supply for the city of Broomfield, Colorado. Design of the system has been completed, and pipeline construction from the alternate water source is well underway. The removal of three "hot spots" in OU 1 may reduce the human health and ecological risk there to a level where a no-action ROD can be proposed.

Ross Complex - Continued groundwater monitoring of OU B is planned for the next 2 to 5 years.

Savannah River Site - Six Removal Actions and 13 Interim Actions were completed. 
Weldon Spring Site Remedial Action Project - The demolition of 15 Chemical Plant Site buildings, and a CERCLA removal action were completed. The removal of the Quarry bulk waste under an ROD signed in 1991 is continuing. Design was completed and construction initiated for a Pilot Sludge Processing Facility.

Additional information on cleanup initiatives undertaken at DOE NPL facilities is provided in the detailed narratives found in Section III of this report.

\section{II.H. Progress in Performing Cleanup Activities at Facilities Not on the NPL}

Many DOE facilities that are not listed on the NPL are conducting cleanup activities. Highlights of some of these activities are presented below.

Pinellas Plant - Data collection began for the Remedial Action Plan at the 4.5 Acre Site. The Corrective Measures Study was submitted for the Northeast Site. An RFI for the West Fenceline Area was completed and approved.

Nevada Test Site - A preliminary Risk Assessment and Draft Cost/Benefit Analysis for large areas of soils contaminated with plutonium from past activities were completed. Several RCRA closure activities were initiated during FY 94, including the Area 27 closure. Additional characterization and groundwater monitoring wells were installed as part of an effort to develop a regional groundwater model for predicting contaminant transport.

Additional information on cleanup initiatives undertaken at facilities not listed on the NPL is provided in the detailed narratives found in Section IV of this report. 
SECTION III

SITE SUMMARIES FOR FACILITIES ON THE NPL (BY STATE) 


\section{SITE SUMMARIES FOR FACILITIES ON THE NPL (BY STATE)}

This section of the annual report to Congress provides a detailed description of progress made at each of the 23 U.S. Department of Energy (DOE) facilities currently on the National Priorities List (NPL). The information provided includes each facility's NPL status, background summary information, environmental conditions, and funding information. Each of the applicable Comprehensive Environmental Response, Compensation, and Liability Act (CERCLA) Section 120(e)(5) information requirements is also addressed. Figure II-1 presents the geographic location of the NPL sites highlighted in this section. 
This Page Intentionally Left Blank.

III-2 


\title{
LABORATORY FOR ENERGY - HEALTH RESEARCH
}

\author{
Davis, California
}

Office:

Oakland Operations Office

Size:

15 acres $(0.02$ square mile)

NPL Status:

Placed on NPL on May 31, 1994

Mission:

The Laboratory for Energy-Health Research (LEHR) facility consists of several DOE-owned buildings located on property leased from the University of California, Davis (UCD). LEHR was established in 1958 by the Atomic Energy Commission to conduct research of health effects on dogs exposed to bone-seeking radionuclides. Full-scale experimental use of radioactive materials, including strontium- 90 and radium-226, began at the LEHR site in 1960.

Overview of

Environmental Conditions:

The contaminants are primarily strontium- 90 and raduim- 226 in buildings and tanks and organics, radionuclides and trace metals in soil and groundwater. Tritium has also been detected. Offsite groundwater contamination consists of chromium and nitrates. Between the 1940s and 1967, an approximately 6-acre portion of the site was used by UCD as a sanitary landfill and low-level radioactive waste disposal area. Routine laboratory and university refuse, including chemical waste, was disposed of at this site.

CERCLA Funding in FY 94:

$\$ 3,207,000$

\section{Progress in Reaching Interagency Agreement}

In 1988, DOE terminated the research program and in 1989 signed a Memorandum of Agreement with UCD to begin cleanup of the site to return it to UCD. DOE, U.S. Environmental Protection Agency (EPA) Region IX and the State of California are currently formulating a Federal Facility Agreement (FFA) for cleanup of LEHR.

\section{Specific Cost Estimates and Budgetary Proposals Involved in Each Interagency Agreement}

Funds budgeted for environmental restoration at LEHR total $\$ 0.82$ million of appropriated funding for Fiscal Year (FY) 95 and \$2.5 million for FY 96 according to the request in the President's Budget. These budget figures do not, however, reflect the rescission that occurred in FY 95. 


\section{Public Comments Regarding Interagency Agreements}

An Interagency Agreement (IAG) in the form of an FFA has not been reached, but the neighboring community, special interest groups, local media, and elected officials are concerned about onsite radioactive sources and groundwater contamination.

\section{Progress in Conducting Remedial Investigations/Feasibility Studies}

A Site-wide Remedial Investigation/Feasibility Study (RI/FS) Work Plan has been prepared and is undergoing final approval by the regulators.

\section{Progress in Conducting Remedial Actions}

The expected remedial actions include excavation, segregation, compaction, and offsite disposal of soil, implementation of a groundwater pump and treat system, if required, and remediation of septic tanks. 
LAWRENCE LIVERMORE NATIONAL LABORATORY -

MAIN SITE

Office:

Size:

NPL Status:

Mission:

Overview of

Environmental

Conditions:

CERCLA Funding

in FY 94:

Oakland Operations Office activities. trichloroethylene.

$\$ 17,709,000$
811 acres (1.3 square miles)

Placed on the NPL on July 22, 1987.

The Lawrence Livermore National Laboratory (LLNL) was established in 1952 to function as a national scientific and technical resource for the nuclear weapons program and other programs of national interest. LLNL performs research, development, and testing associated with the nuclear design aspects of all phases of the nuclear weapon life cycle. The Laboratory, consisting of two noncontiguous parcels (Main Site and Site 300 ), is also involved in the following programs: inertial fusion, magnetic fusion, biomedical and environmental research, isotope separation, and applied energy technology and other research-related

Contamination of groundwater and soil with tetrachloroethylene and

\section{Progress in Reaching Interagency Agreement}

DOE entered into an FFA with EPA Region IX and the State of California for cleanup of the LLNL - Main Site. This FFA was executed on November 1, 1988 and became effective in February 1989. Significant emphasis was placed on the renegotiation of FFA enforceable milestone deliverables this fiscal year. In June 1994, EPA and the state agencies approved a revised schedule that reprioritized activities to direct the focus on the western and southern perimeters where there is offsite contamination. A treatability study and groundwater facility were added for Trailer 5475 where there are volatile organic compounds and tritium contamination. The Building 518 vapor extraction system was also included in the schedule.

\section{Specific Cost Estimates and Budgetary Proposals Involved in Each Interagency Agreement}

Funds budgeted for environmental restoration to support the FFA milestones at the LLNL-Main Site total $\$ 17.3$ million of appropriated funding for FY 95 and \$14.6 million for FY 96 according to the 
request in the President's Budget. These budget figures do not, however, reflect the rescission that occurred in FY 95.

\section{Public Comments Regarding Interagency Agreements}

No new comments on the FFA were received in FY 94. An IAG in the form of an FFA became effective in 1989; as a result, a technical assistance group is in place. This group continues to support a community working group to review post Record of Decision (ROD) documents and to provide input into the recent renegotiations and priorities of the site remediation efforts.

\section{Progress in Conducting Remedial Investigations/Feasibility Studies}

The Draft Final Feasibility Study (FS) was submitted to the state and EPA in December 1990 and the proposed Remedial Action Plan was submitted in October 1991, in preparation for the November 1991 public hearing on the proposed plan for onsite remediation activities. A responsiveness summary for the public comments and final ROD was approved by DOE in June 1992.

\section{Progress in Conducting Remedial Actions}

The ROD for the LLNL-Main Site was approved by DOE, EPA, and the State of California in June 1992. The ROD called for cleanup of soil and groundwater using seven treatment facilities and 24 initial extraction locations. In FY 94, construction for treatment facilities C and D were completed and operations began. Currently, five of the originally scheduled seven facilities are now in operation. In FY 93 the Detailed Study Area Pipeline was completed along with closure activities at Building 612. Additionally, a successful demonstration of the Dynamic Underground Stripping Technology was performed at the Gasoline Spill Area, which resulted in the removal of approximately 10,000 gallons of fuel hydrocarbons.

In FY 94 a great many resources have been devoted to the preparation and submission of regulatory required documents. The Final Remedial Design Report No. 3 was completed and issued in FY 94. The Draft and Final Remedial Design Report No. 6 were also submitted in FY 94. The arroyo pipeline installation for connection to Treatment Facility A was completed in August 1994. 


\section{LAWRENCE LIVERMORE NATIONAL LABORATORY - SITE 300

Office:

Size:

NPL Status:

Mission:

Overview of

Environmental

Conditions:

\section{CERCLA Funding} in FY 94:
Oakland Operations Office

7,000 acres (10.1 square miles)

Placed on the NPL on August 30, 1990.

The LLNL was established in 1952 to function as a national scientific and technical resource for the nuclear weapons program and other programs of national interest. LLNL performs research, development, and testing associated with the nuclear design aspects of all phases of the nuclear weapon life cycle. The Laboratory consists of two noncontiguous parcels, the Main Site and Site 300 . Site 300 is used for high explosives testing.

Contamination of onsite groundwater and soil with tritium and trichloroethylene and high explosive compounds.

\section{Progress in Reaching Interagency Agreement}

An integrated (CERCLA/Resource Conservation and Recovery Act [RCRA]) FFA was negotiated and signed between DOE, EPA Region IX, the California EPA's Department of Toxic Substance Control, and the Central Valley Regional Water Quality Control Board in June 1992.

In February 1994 a revised Appendix A (schedule of deliverables) to the FFA was approved by EPA. This schedule was revised to redefine the operable units, add additional site characterization field work, and provide an overall extension of the schedule.

\section{Specific Cost Estimates and Budgetary Proposals Involving Each Interagency Agreement}

Funds budgeted for environmental restoration to support the milestones in the FFA at the LLNL-Site 300 total $\$ 8.7$ million of appropriated funding for FY 95 and $\$ 10.9$ million for FY 96 according to the request in the President's Budget. These budget figures do not, however, reflect the rescission that occurred in FY 95. 


\section{Public Comments Regarding Interagency Agreements}

All stakeholders and interested parties were given the opportunity to review the renegotiated schedule and priorities for LLNL-Site 300 prior to revision in FY 94.

\section{Progress in Conducting Remedial Investigations/Feasibility Studies}

Under the terms of the FFA and at the request of the regulatory agencies, a draft of the Site 300 Site Wide Remedial Investigation (SWRI) Report has been prepared. Under the original Remedial Investigation (RI) schedule, the RI was due in January 1993. A revised schedule for the RI set a new milestone of August 9, 1993. The final SWRI Report was submitted to the regulators on March 10, 1994. The revised schedule required characterization plans for four operable units (OU); these were submitted in FY 94.

Based on the results of the SWRI, individual OU FSs will be prepared. The OUs under the FFA are: Building 834 Area, the General Services Area (GSA), the High Explosive Process Area, the Pit 6 Complex, East/West Firing Areas, and an "other miscellaneous areas of concern" OU, including Building 833 and the dry wells. In November 1993, a draft FS for the GSA (OU 1) was prepared. The delivery of this document, however, is being negotiated due to the need for additional characterization in the report. Preparation of the other five documents is underway, and DOE Headquarters has reviewed the FS for the Building 834 Area, which was sent on February 1, 1994. Restart of the Interim Soil Vapor Extraction Facility at Building 834 is expected to begin during the first quarter of FY 95.

Draft and Final FSs for Building 834 (OU 2) were also prepared and submitted during FY 94. Preparation of subsequent documents is currently underway and on schedule. A draft FS for OU 3/Pit Complex was submitted in FY 94.

\section{Progress in Conducting Remedial Actions}

The Interim Groundwater Facility at the Eastern GSA was initiated in FY 92 and continues to operate. An Interim Groundwater Treatment Facility continues to operate at the Central GSA. Proof of system testing and restart of the Interim Soil Vapor Extraction Facility at Building 834 were initiated in FY 94. 
Office:

Size:

NPL Status:

Mission:

Overview of

Environmental

Conditions:
Rocky Flats Operations Office

6,550 acres (10.2 square miles)

Placed on the NPL on October 4, 1989.

The mission of the Rocky Flats Environmental Technology Site (RFETS), formerly the Rocky Flats Plant, is to manage waste and materials, and to clean up and convert the site for beneficial use in a manner that is environmentally safe and socially responsible, physically secure, and cost-effective.

Onsite contamination of soil, groundwater, and surface water by chemical and radioactive materials used at the facility. Offsite soil contamination also has been identified.
CERCLA Funding in FY 94:
$\$ 103,485,000$

\section{Progress in Reaching Interagency Agreement}

DOE, EPA Region VIII, and the State of Colorado executed an IAG for the RFETS on January 22, 1991. The IAG supersedes the RCRA/CERCLA Compliance Agreement executed on July 31, 1986 among DOE, EPA Region VIII and the State of Colorado. The IAG establishes cleanup schedules and delineates regulatory responsibilities of EPA Region VIII and the State of Colorado. In January 1994, it was agreed among EPA Region VIII, the Colorado Department of Public Health and Environment (CDPHE), and DOE that a new Rocky Flats Cleanup Agreement will be negotiated to replace the IAG. These negotiations will continue until at least January 31, 1995.

\section{Specific Cost Estimates and Budgetary Proposals Involved in Each Interagency Agreement}

Funds budgeted for environmental restoration under the IAG total $\$ 94.9$ million of appropriated funding for FY 95 and $\$ 86.6$ million for FY 96 according to the request in the President's Budget. These budget figures do not, however, reflect the rescission that occurred in FY 95. 


\section{Public Comments Regarding Interagency Agreements}

Discussions began in FY 93 between DOE and the regulatory agencies regarding negotiation of the new Rocky Flats Cleanup Agreement. The public has been kept abreast of this activity, and a preliminary draft of the agreement was provided for informal comment. Public comment occurred in FY 94 via several forms, including workshops, monthly meetings, and a local bulletin board dedicated to negotiations.

\section{Progress in Conducting Remedial Investigations/Feasibility Studies}

Initial site characterization efforts at RFETS began in July 1986 under the RCRA/CERCLA Compliance Agreement and continue under the IAG executed on January 22, 1991. A comprehensive list of all known and suspected hazardous, radioactive, and mixed waste sources at the RFETS has been compiled, including descriptions of all known release information for 178 individual hazardous substance sites. These sites have been categorized for further environmental investigation and remediation into 16 OUs based on cleanup priorities, waste type, geographic location, and public input. A no-action ROD has been approved by DOE, EPA and the CDPHE for one operable unit (OU 16).

Phase I RI work plans for all 15 remaining OUs have been approved by the regulatory agencies. The number of Phase II work plans has been reduced by innovative planning and working with the regulatory agencies to combine the Phase I and Phase II field work for several OUs. Phase I RI field work has been completed for eight OUs and is underway in the remaining seven. One final (OU 1) and two draft (OUs 2 and 15) RI reports have been submitted to the regulatory agencies, and RI reports are underway in the other OUs where the RI field work has been completed. Feasibility studies (FSs) have been started in four OUs. In some operable units where presumptive remedies or no-action RODs will be sought, scaled-down FSs will be utilized with approval from the regulatory agencies to reduce costs. Accelerated removal actions conducted under a proposed action memorandum procedure, developed in conjunction with the regulatory agencies, may also reduce the risk at some OUs so that a no-action ROD may be approved, further reducing remediation costs.

RI field work for OU 1 is complete, and the 14-volume final RI report was delivered to EPA and the CDPHE on its extended milestone delivery date in June 1994. The OU 1 FS was completed in FY 94, with an evaluation of the list of remediation alternatives based on the revised interpretations of the nature and extent of contamination in the final RI. The draft FS Report was submitted in August 1994.

The alluvial portion of the OU 2 RI field work was completed in FY 92, the bedrock portion was completed in FY 93, and the preliminary draft RI report was delivered to the regulatory agencies in December 1993. The final draft and final OU 2 RI Reports are scheduled to be delivered to the regulatory agencies in May and September 1995, respectively. The original delivery dates in the second quarter of FY 92 for the draft and final OU 2 RI report, both LAG milestones, could not be met. Because the regulatory agencies denied an extension request for this milestone and for delivery of the final RI report, scheduled for late FY 93, these are considered missed IAG milestones. The two missed OU 2 milestones are included in the Tolling Agreement, which is deferring penalties on selected missed milestones through August 1, 1995 in exchange for a "toll" paid to the regulatory agencies. Effort on the OU 2 FS will continue through FY 95.

In OU 3, Offsite Areas, the Environmental Evaluation field work, reservoir sediment and water sampling, installation and sampling of groundwater wells, and development of the Wind Tunnel field sampling plan were completed. The Wind Tunnel field work, designed to quantitatively determine the 
resuspension potential of OU 3 surface soils, was completed during July 1993. The resuspension potential is a component in the inhalation pathway section of the Human Health Risk Assessment. Preparation of the OU 3 RI Report will continue during FY 95 and be completed in FY 96.

Approximately 80 percent of the OU 4, Solar Evaporation Ponds, Phase I Assessment was completed in FY 94. Based on the 1993 dispute resolution with CDPHE and EPA, this degree of completeness was sufficient to proceed with development of the Interim Measure/Interim Remedial Action (IM/IRA) Decision Document for closure of the ponds. The Phase II RCRA Facility Investigation/Remedial Investigation (RFI/RI) Work Plan was completed and approved by the regulatory agencies, and the Phase II field work will be completed in FY 95

The Phase II RI field work for OU 5 was combined with the Phase I RI so that only one RI Report will be required, the draft of which will be delivered to the regulatory agencies in July 1995 . Use of a presumptive remedy for remediation of the most contaminated sites in OU 5 will reduce the scope of the FS which is underway. If the Preble's Meadow jumping mouse, which has habitat in OU 5 and other buffer zone operable units, is added to the endangered species list as expected, field work in OU 5 may be delayed. RI field work for OU 6 has been completed, and the RI Report is being prepared. The draft OU 6 RI Report will be completed in FY 95, and the final report will be completed in FY 1996.

The two phases of OU 7 were combined with regulatory agency approval. This, along with use of a presumptive remedy to cap the present landfill, deleted 10 IAG milestones from this subproject. OU 7 field work will be completed in FY 95. The field work for OUs 11 and 15 were completed, and the RI report for OU 15 was delivered to the regulatory agencies in July 1994. The RI report for OU 11 will be completed in FY 95. It is anticipated that no-action RODs will be proposed for these two operable units.

Non-intrusive field work for OUs $8,9,10,12,13$, and 14, which are located within the RFETS industrial area, continued in FY 94. Eight IAG milestones in the industrial area operable units, which were scheduled for completion in FY 94, are included in the Tolling Agreement. The Tolling Agreement defers penalties on selected missed milestones through January 30, 1995 in exchange for a "toll" paid to the regulatory agencies. It is anticipated that the operable units within the industrial area will be reconfigured in the new Rocky Flats Cleanup Agreement or by a modification to the existing IAG, and current milestones will be replaced by new enforceable milestones.

Intrusive field work in the reconfigured industrial area operable units will not begin until the work is integrated with future decommissioning of facilities and other plant transition activities in this location. Coordination of all these activities will be addressed in the RFETS integrated planning process. Early cleanup or removal actions could occur for selected hot spots of concentrated contamination in these operable units if the need is identified.

A no-action ROD was proposed and has been approved for five of the original seven Individual Hazardous Substance Sites in OU 16. The other two Individual Hazardous Substance Sites were transferred to other operable units for further investigation, thereby completing all OU 16 activity.

In September 1993, the EPA and Rocky Flats Field Office presented a Superfund Innovative Technology Evaluation (SITE) demonstration. This demonstration included a general plant tour of RFETS and a viewing of the technology site, accompanied by a briefing about the SITE demonstration technology. The demonstration of the Colloid Polishing Filter Method technology conducted at RFETS showed removal efficiencies of up to 90 percent for uranium and 86.8 percent for gross alpha. 
The demonstration and results are discussed in several EPA publications available through the Office of Research and Development in Cincinnati, Ohio.

A new RFETS Environmental Restoration Community Relations Plan was written and is pending approval by EPA and the CDPHE. During FY 94, the following community relations activities were accomplished:

- Six Environmental Restoration Update newsletters were issued to the public

- Four quarterly public information meetings were held.

- The Technical Review Group continued to meet monthly to provide early public input on draft documents to the regulatory agencies.

- Monthly coordination meetings were held with EPA and CDPHE.

- All required documents were placed in RFETS public reading rooms and five other repositories.

- Tours, presentation, and briefings on various topics were presented to members of the public including the Rocky Flats Citizens Advisory Board and the Rocky Flats Local Impacts Initiative.

- Two fact sheets were produced and numerous citizen questions were answered verbally and in writing.

- There were three formal public comment periods on various documents as required by CERCLA.

- There were numerous updates on the Rocky Flats Cleanup Agreement, including a workshop which resulted in a list of community values and concerns which were used in the development of the document.

- A workshop was given for stakeholders on environmental laws and regulations. About 70 members of the public attended the day-and-a-half workshop.

\section{Progress in Conducting Remedial Actions}

After public comments and regulatory agency design approval, an interim remedial action (IRA) for OU 1 (a french drain groundwater collection system and Building 891 treatment facility) was constructed and placed into operation in May 1992. The OU 1 IRA treatment facility collected and treated over 2.6 million gallons of potentially contaminated groundwater through FY 94. Sampling has verified that contamination levels of the water being collected by the OU I IRA from the Building 881 footing drain is within acceptable limits, and authorization was granted by the regulatory agencies in 1994 to cease pumping this water to the french drain. This source accounted for 85 to 95 percent of the water treated by the OU 1 IRA.

An IRA for OU 2 which collects, treats, and releases potentially contaminated surface water was completed and placed into operation in April 1992. The OU 2 IRA treatment facility has collected and treated over 24 million gallons of potentially contaminated surface water. Sampling has verified 
that the contamination level of the water being collected from two of the three surface water sources by the OU 2 IRA, which account for about 90 percent of the surface water collected, is within acceptable limits. Authorization to cease collection and treatment of water from these sources was granted by the regulatory agencies in 1994.

A second IRA for OU 2 was mandated by the regulatory agencies in FY 1991. The Phase I design of this IRA, which is evaluating conventual vacuum-enhanced vapor extraction technology to extract volatile organics from vadose-zone soils, was approved by the regulatory agencies, and construction was completed in the first quarter of FY 94. Approximately 915 pounds of volatile organic materials have been removed from the ground, processed, and disposed of.

Option B Offsite Water Projects funded by DOE through grants to local municipalities include replacement of the drinking water supply for the City of Broomfield, Colorado. Design of the system has been completed, and pipeline construction from the alternate water source is well underway. Also included under Option B is construction of the Standley Lake Protection Project. This work was started in FY 94 following resolution of endangered species and wetlands issues.

RFETS is aggressively pursuing accelerated removal actions to reduce risks in a number of operable units. The removal of three "hot spots" (small volumes of soil with relatively high radioactive contamination) in OU 1 may reduce the human health and ecological risk in OU 1 to a level where a no-action ROD can be proposed. Other accelerated actions, including removal of additional hot spots, storage yard materials and debris, old sprinkler pipes, underground tanks, etc., are being planned for FY 95

During FY 94, procurement and certification of above-ground sludge storage tanks for the OU 4 solar ponds were completed. Upon certification of the tanks, sludge removal operations commenced in the unemptied solar evaporations ponds utilizing commercially available vacuum tanker trucks. This operation proved to be extremely effective in removing sludge from the ponds, thereby minimizing further introduction of contaminants to the environment. By the end of FY 94, operations were proceeding in the last pond that contained water and sludge. Sludge removal operations will be completed in early FY 95.

The OU 4 Interceptor Trench System was in operation throughout the year collecting potentially contaminated near-surface groundwater and surface runoff. Nearly 2.5 million gallons were collected, stored in temporary holding tanks, and ultimately processed by two evaporative water treatment facilities located at RFETS. An upgrade in the higher capacity building has allowed a phased shutdown in the dedicated treatment facility. Work began in FY 94 to place the facility in a standby condition and will be completed in FY 95. Significant cost savings will be realized by the operation of only one treatment facility.

The OU 4 remediation methodology was modified several times during the fiscal year. The Draft Phase I Proposed IM/IRA Decision Document was delivered to regulatory agencies in May 1994 and included the proposed treatment scenario, which called for 1,000-year protection of the solar pond area below an engineered cap. The cap design would include consolidation of the solar pond liners in one of its levels. The design was later modified to include disposition of specific remediation wastes that include minimally treated sludge from the ponds and failed pondcrete from earlier pond sludge remediation activities. The latest proposal will provide all required protection to the public and the environment and save nearly $\$ 80$ million in life cycle costs over other options. This approach is fully supported by the DOE and EPA, but the State of Colorado is withholding judgment until after public 
comment. Resolution will occur in FY 95, with actual construction activities beginning in early FY 97.

Implementation of a wetlands mitigation effort in the area of the OU 1 french drain was completed ahead of schedule. Cattails, sedges, bulrush, three square, and willows were successfully planted on the 881 Hillside as a part of the revegetation plan after the area was lined with bentonite.

Construction of the new wetlands was added to the original scope after it became evident that there would be a loss of some wetlands associated with the construction of the OU 1 IM/IRA french drain. Growth of the wetland vegetation was examined, and the regulatory agencies were pleased with the work accomplished.

The final draft of the Pond Water Management IM/IRA was completed and submitted to CDPHE and EPA on November 23, 1993. The draft was required to be developed under the IAG by the regulatory agencies in 1992, even though there is no imminent hazard to public health or the environment from water on the plant site. The document went to dispute under the IAG; the parties met on April 15, 1994 and came to a resolution on dispute issues. DOE has not agreed with the use of CERCLA in lieu of the Clean Water Act to regulate surface waters, so as part of the resolution, language addressing the designation of the ponds as "waters of the U.S." and preservation of DOE's rights to appeal this issue was included.

\section{Enforcement Activities}

On July 7, 1994, a Rocky Flats Tolling (Settlement) Agreement was signed by the DOE Manager of RFETS and officials from the CDPHE and the EPA Region VIII. This agreement includes a settlement of $\$ 2,800,000$ for 14 missed or expected to be missed enforceable IAG milestones for the period of March 1993 through January 1995. This settlement payment includes cash payments of $\$ 350,000$ each to the CDPHE and the EPA, and $\$ 2,100,000$ in Special Environmental Projects related to, at, or in the vicinity of RFETS. It is anticipated that a new Rocky Flats Cleanup Agreement will be negotiated and approved by January 30, 1995 which will contain revised dates for completion of the missed milestones or new milestones to replace the missed milestones. If the Rocky Flats Cleanup Agreement is not approved by January 30, 1995, or other means to resolve the milestone issue with the regulatory agencies are not reached, DOE could be liable for stipulated penalties for missing the enforceable milestones in the Tolling Agreement and future milestones that are likely to be missed. 


\title{
IDAHO NATIONAL ENGINEERING LABORATORY
}

\author{
Idaho Falls, Idaho
}

Office:

Size:

NPL Status:

Mission:

Overview of

Environmental

Conditions:
Idaho Operations Office

569,600 acres (890 square miles)

Placed on the NPL on November 21, 1989.

The Idaho National Engineering Laboratory (INEL) was established in 1949 by the U.S. Atomic Energy Commission as an area to build, test, and operate various nuclear reactors, fuel processing plants, and support facilities with maximum safety and isolation. Originally known as the National Reactor Testing Station, the site was renamed as the INEL in 1974 to reflect the broad scope of engineering activities now conducted at the site. Prior to its establishment, the site was used as a World War II gunnery range for the U.S. Navy and U.S. Army Air Corps.

Onsite groundwater and soil contamination from both known and potential sources resulting from past disposal practices. Contaminants of concern include chromium, volatile organic compounds (VOCs), carbon tetrachloride, and radionuclides.

CERCLA Funding in FY 94:

\section{Progress in Reaching Interagency Agreement}

The INEL Federal Facility Agreement/Consent Order (FFA/CO) and Action Plan between DOE, EPA Region X, and the State of Idaho was executed on December 9, 1991. The FFA/CO supersedes the RCRA 3008(h) Consent Order and Compliance Agreement (COCA) and covers all CERCLA response requirements as well as RCRA corrective action requirements. All parties agreed to initiate the FFA/CO Action Plan under the COCA in September 1991 while the FFA/CO was being finalized. The FFA/CO also includes Argonne National Laboratory (ANL) - West and the Naval Reactors Facility (NRF), which are located at INEL.

\section{Specific Cost Estimates and Budgetary Proposals Involved in Each Interagency Agreement}

Funds budgeted for environmental restoration under the IAG Action Plan at the INEL total $\$ 107.5$ million of appropriated funding for FY 95 and $\$ 76.9$ million for FY 96 according to the 
request in the President's Budget. These budget figures do not, however, reflect the rescission that occurred in FY 95.

\section{Public Comments Regarding Interagency Agreements}

No new public comments concerning the IAG were received in FY 94.

\section{Progress in Conducting Remedial Investigations/Feasibility Studies}

RI/FS activities are under way or complete at all of the ten Waste Area Groups (WAG). Under the IAG, OUs have been defined so that all known solid or hazardous waste units will be addressed appropriately. To facilitate environmental remediation efforts, the site was divided into 10 WAGs, which generally correspond to major INEL operational facilities. Previous identification of releases at three facilities had led to the NPL listing in 1989. The three facilities are Test Area North (WAG-1), Test Reactor Area (WAG-2), and Radioactive Waste Management Complex (WAG-7).

WAG-10 was established to encompass the Snake River Plain aquifer and all activities that affect groundwater on a regional scale, and includes all sites that are outside of the facility-specific WAGs.

The following documents were developed and submitted to the EPA and State of Idaho during FY 94 at the INEL:

- 30 No Further Action Determinations approved;

- Draft Final RA Work Plan for the Test Area North Injection Well (OU 1-07A);

- Draft Final Remedial Design for Test Area North Injection Well (OU 1-07A);

- $\quad$ Draft PP for Test Area North Groundwater (OU 1-07B);

- Draft Final ROD for Test Area North Groundwater (OU 1-07B);

- $\quad$ Draft Final RI/FS Report Test Area North Groundwater (OU 1-07B);

- $\quad$ Prefinal Inspection Report for Test Reactor Area Warm Waste Pond (OU 2-10);

- Draft Final RA Report Test Reactor Area Warm Waste Pond (OU 2-10);

- Data Transmittal Package (four rounds of data transmittal) Test Reactor Area Perched Water (OU 2-12);

- $\quad$ Draft RI/FS Statement of Work for WAG 2 Comprehensive RI/FS (OU 2-13);

- $\quad$ Draft RI/FS Statement of Work for WAG 3 Comprehensive RI/FS (OU 3-13);

- Draft RI Report for Central Facilities Area Landfills (OU 4-12);

- $\quad$ Draft RI/FS Report for Central Facilities Area Landfills (OU 4-12); 
- Draft Final RI/FS Statement of Work Report Auxiliary Reactor Area (ARA) Stationary Low Power Reactor-1 (SL-1) Burial Ground (OU 5-05) and Boiling Water Reactor Experiment Reactor (BORAX) I Burial Site (OU 6-01);

- Draft RI Report ARA SL-1 Burial Ground (OU 5-05) and BORAX I Burial Site (OU 6-01); Draft RU/FS Report ARA SL-1 Burial Ground (OU 5-05) and BORAX I Burial Site (OU 6-01);

- Draft Final RD/RA Work Plan for the Power Burst Facility Evaporation Pond (OU 5-13);

- Draft Final RI/FS Report for Organic Contamination in the Vadose Zone (OU 7-08);

- $\quad$ Proposed Plan for Organic Contamination in the Vadose Zone (OU 7-08);

- Draft Final ROD for Organic Contamination in the Vadose Zone (OU 7-08) and signed 2/17/94;

- Draft and Final Treatability Study for Organic Contamination in the Vadose Zone (OU 7-08);

- Subcontractor Preliminary Design for Pit 9 (OU 7-10);

- Draft Final ROD for Pad A (OU 7-12);

- Initial Draft RD/RA Statement of Work for Pad A (OU 7-12);

- Draft RD/RA Work Plan for Pad A (OU 7-12);

- $\quad$ Draft RI Report for NRF Waste Ditch (OU 8-07);

- Draft RI/FS Report for NRF Waste Ditch (OU 8-07);

- $\quad$ Proposed Plan for NRF Waste Ditch and Landfills (OU 8-05, 06, \& 07);

- Draft Final ROD for NRF Industrial Ditch and Landfills (OU 8-05, 06 \& 07);

- Issue Prefinal Inspection Report for the Ordnance Interim Action (OU 10-05);

- Draft Final RA Report for the Ordnance Interim Action (OU 10-05);

- Draft Final RI/FS Statement of Work for the Ordnance Interim Action (OU 10-05); and

- Draft Final Field Sampling Plan and Health and Safety Plan for Radiologically Contaminated Soils at the INEL (OU 10-06). 


\section{Progress in Conducting Remedial Actions}

The following activities were accomplished in FY 94 at the INEL:

\section{$\underline{\text { Assessment }}$}

- 17 of 25 RODs complete or underway;

- Completed 32 assessment, extraction and monitoring wells (cumulative depth 8,500 feet);

- Submitted Draft Final Radioactive Waste Management Complex Organic Contamination in the Vadose Zone Record of Decision (OU 7-08) to the EPA and Idaho Department of Health and Welfare on October 3, 1993;

- Completed Aquifer Pumping and Infiltration Test field work;

- Completed INEL Ecological Risk Assessment Guidance Manual and all Waste Area Group specific screening level ecological risk assessments; and

- Completed regional-scale groundwater flow model.

\section{Cleanup}

- Removal Action - Test Area North Injection Well Site (OU 1-07A) processed 357,000 gallons of water from the Snake River Plain Aquifer and removed 3,000 pounds of organic waste trichloroethylene/perchloroethylene. The wastes are planned to be disposed at Rollins Environmental in Texas City, Texas in the near future;

- Interim Action - Completed excavation of 240 cubic yards of calcine-contaminated soil (mercury contamination) from Central Facilities Area Pond site (OU 4-05);

- Interim Action - Completed excavation, boxing, and disposal of 285 cubic yards of hazardous, radioactive soil from Power Burst Facility Evaporation Pond site (OU 5-13, chromium and low levels of cesium);

- $\quad$ Reduced soil contamination by 9.6 acres at SL-1 Burial Grounds (OU 6-01) through particle picking;

- Placed 3,500 cubic yards of soil on Pad A to stabilize the existing soil cover; and

- Removal Action - Three 16-inch shells, 24 pounds of RDX explosive material, and 55,000 pounds of scrap metal removed from ordnance sites (OU 10-03). The explosive ordnance waste will continue to be disposed at INEL in the Central Facilities Area landfill following detonation and approved certification. 


\title{
PADUCAH GASEOUS DIFFUSION PLANT
}

\author{
Paducah, Kentucky
}

Office:

Size:

NPL Status:

Mission:

Overview of Environmental Conditions:
Oak Ridge Operations Office

3,423 acres ( 5.3 square miles)

Placed on the NPL on May 31, 1994

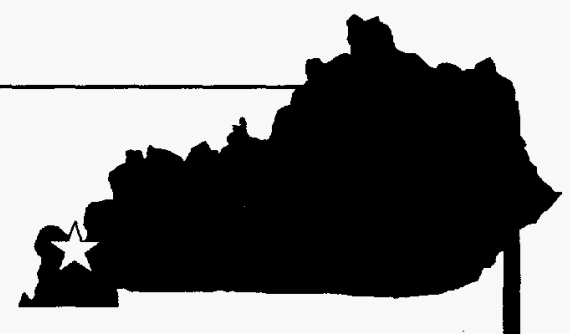

The Paducah Gaseous Diffusion Plant, established in 1950 on the grounds of the old Kentucky Ordnance Works Trinitrotoluene Plant, is actively engaged in the enrichment of uranium using gaseous diffusion technology. Most of the uranium output from the plant is designated for the commercial sector. In July 1993, DOE officially transferred responsibility for site operations to the U.S. Enrichment Corporation (USEC) in accordance with the Energy Policy Act of 1992.

The site consists of 197 Solid Waste Management Units (SWMUs) and areas of concern, which have been divided into 24 WAGs. Onsite chemical contamination of soils was identified. Offsite groundwater contamination consists of trichloroethylene and technetium-99, offsite creek sediment contamination consists of PCBs.

CERCLA Funding in FY 94:

$\$ 21,310,000$

\section{Progress in Reaching Interagency Agreements}

Although Paducah Gaseous Diffusion Plant is listed on the NPL, remediation is currently being addressed under authority of a RCRA 3008(h) Administrative Consent Order that was signed November 4, 1988, and a RCRA Part B Permit (referred to as a Hazardous and Solid Waste Amendments permit) that was jointly issued by EPA and the State of Kentucky on July 16, 1991. DOE is working with EPA and the state to develop an IAG; while negotiations are still underway, and the completion date for the agreement is expected to occur during the first half of 1995.

\section{Specific Cost Estimates and Budgetary Proposals Involved in Each Interagency Agreement}

Funds budgeted for environmental restoration at Paducah Gaseous Diffusion Plant total \$38.9 million of appropriated funding for FY 95 and $\$ 23.2$ million for FY 96 according to the request in the President's Budget. These budget figures do not, however, reflect the rescission that occurred in FY 95. 


\section{Public Comments Regarding Interagency Agreements}

Because the IAG is currently under development, the public has not commented on the IAG.

\section{Progress in Conducting Remedial Investigations/Feasibility Studies}

The Administrative Consent Order for Paducah Gaseous Diffusion Plant was executed by DOE and EPA on November 4, 1988. The RCRA Part B Permit with EPA and the State of Kentucky was executed on July 16, 1991. During FY 94, work completed or under way at Paducah Gaseous Diffusion Plant was as follows:

- Submittal and signing of the north-south Diversion Ditch interim action ROD;

- $\quad$ Completion of RI fieldwork for WAG 1 and WAG 7;

- Continued development of the WAG $22 \mathrm{RI} / \mathrm{FS}$;

- Continued investigation of northeast plume characterization and groundwater (Phase IV);

- $\quad$ Continued water policy Phase III;

- Continued sampling of approximately 140 groundwater monitoring wells and 30 residential wells;

- $\quad$ Submittal of two RI workplans, one RI addendum, and one FS/PP;

- Continued negotiation of the FFA; and

- Continued development of the waste management strategy and site treatment plan.

\section{Progress in Conducting Remedial Actions}

During FY 94, the following work was completed or underway at Paducah Gaseous Diffusion Plant was as follows:

- Construction of northwest Plume Treatment Facility;

- Continued development of dense nonaqueous phase liquid technology;

- Completion of monitoring well abandonment;

- Construction of the decontamination pad and field support laboratory; and

- Continued storage and shipment of waste for treatment and/or disposal. 
ST. LOUIS SITE

Hazelwood, Missouri

(St. Louis Airport Site and

Vicinity Properties, Latty Avenue

Properties, and St. Louis Downtown Site)

Office:

Size:

NPL Status:

Mission:

Overview of

Environmental

Conditions:
Oak Ridge Operations Office

21.7 acres $(0.03$ square mile)

Placed on the NPL on October 4, 1989, except St. Louis Downtown Site, which is not an NPL site.

The St. Louis Site, established as a storage site in 1946, stores residues, contaminated scrap, and equipment generated by processing plants in St. Louis from 1946 to 1969 . Cleanup authority at the site was acquired by DOE under a Congressional mandate and is managed by DOE under its Formerly Utilized Sites Remedial Action Program (FUSRAP). FUSRAP sites comprise sites formerly associated with the Manhattan Engineer District Project and the Atomic Energy Commission. Because these sites are not owned or operated by DOE, they do not appear on the docket.

Onsite soil and groundwater contamination by radioactive constituents Offsite soil and sediment contamination also identified.

CERCLA Funding in FY 94:

$\$ 3,160,000$

\section{Progress in Reaching Interagency Agreement}

DOE and EPA Region VII executed an FFA for the St. Louis Site on June 26, 1990. The St. Louis Site consists of the St. Louis Airport Site and Vicinity Properties, and Latty Avenue Properties, all of which were added to EPA's NPL in October 1989. An additional site, not included in the original 1989 NPL, is being addressed in accordance with requirements stipulated in the FFA to make the remediation process more efficient. This site, identified as the St. Louis Downtown Site, is now part of DOE's FUSRAP program. 


\section{Specific Cost Estimates and Budgetary Proposals Involved in Each Interagency Agreement}

Funds budgeted for environmental restoration under the FFA total $\$ 6.6$ million of appropriated funding for FY 95 and \$22.8 million for FY 96 according to the request in the President's Budget. These budget figures do not, however, reflect the rescission that occurred in FY 95.

\section{Public Comments Regarding Interagency Agreements}

No new public comments regarding the FFA were received in FY 94.

\section{Progress in Conducting Remedial Investigations/Feasibility Studies}

The RI/FS-Environmental Impact Statement (RI/FS-EIS) work plan for the St. Louis Site was approved by EPA Region VII in calendar year 1991. A public scoping meeting for the preparation of an RI/FS-EIS was held in January 1992. An RI report was approved by EPA Region VII in 1992. Some limited additional field investigation was performed in FY 92 to supplement the existing characterization data. The Initial Screening of Alternatives was approved by EPA Region VII in FY 92. Based on the results of the Initial Screening of Alternatives, an FS was prepared and issued for review to EPA Region VII and the State of Missouri in FY 93.

EPA has delayed final approval of the FS, and DOE has agreed to reconsider the remedy selection proposed in the draft proposed plan. EPA and DOE have agreed to defer the ROD for approximately 1 year in order to solicit input from a St. Louis stakeholder group. This group, named the St. Louis Site Remediation Task Force, was established in September 1994. It consists of elected officials, state and Federal regulators, public health officials, utility and business representatives, and interested citizens.

\section{Progress in Conducting Remedial Actions}

Final remedial action will be implemented following signing of an ROD. Proposals for interim cleanup measures have been made for properties in the vicinity of the St. Louis Airport Site, and activities will begin in early FY 95. Modest interim cleanup measures have been completed at the St. Louis Downtown Site to accommodate site infrastructure work conducted by the site owner, Mallinckrodt Incorporated. 
Office:

Size:

NPL Status:

Mission:

Overview of Environmental Conditions:

CERCLA Funding in FY 94:
Oak Ridge Operations Office

226 acres ( 0.4 square mile)

Quarry placed on the NPL on July 22, 1987 and Chemical Plant and Raffinate Pits placed on the NPL on March 13, 1989.

The Weldon Spring Site was developed by the U.S. Army for explosives production during World War II, and was operated by the Atomic Energy Commission from 1955 to 1966 as a uranium processing plant.

Soil, surface water, groundwater, and building rubble contamination resulting from the handling and disposal of uranium ore concentrates and scrap.

$\$ 39,702,000$

\section{Progress in Reaching Interagency Agreement}

DOE and EPA Region VII entered into an FFA, signed on August 12, 1986. An amended FFA was signed on June 30,1992 . Further amendments are being negotiated which will make Missouri a signatory to the agreement. Discussion of FFA modification occurred in FY 94 and is expected to continue in FY 95.

\section{Specific Cost Estimates and Budgetary Proposals Involved in Each IAG Interagency Agreement}

Funds budgeted for environmental restoration under the FFA at the site total \$53.2 million of appropriated funding for FY 95 and $\$ 67.5$ million for FY 96 according to the request in the President's Budget. These budget figures do not, however, reflect the rescission that occurred in FY 95 .

\section{Public Comments Regarding Interagency Agreements}

The public comment period for the FFA began on March 22, 1992 and remained open for 45 days. No comments were received during this period. Public comments will be invited on the FFA amendments being negotiated during 1995 . The outcome of the public comment period will be addressed in the FY 95 report to Congress. 
EPA Region VII will publish notices of availability of the amended FFA and will provide a public comment period; the date of publication has not yet been determined.

\section{Progress in Conducting Remedial Investigations/Feasibility Studies}

Initial work was started under a CERCLA/National Environmental Policy Act (NEPA) FFCA executed in 1986. Subsequently, the site was placed on the NPL in July 1987. The Weldon Spring Site project issued a work plan in August 1988 which presented the overall strategy for accomplishing remedial actions. That strategy included the development of an umbrella RI/FS for the Chemical Plant Area, an RI/FS for Quarry bulk wastes, an RI/FS for Quarry residuals, and several interim response actions. A need was subsequently identified to specifically address groundwater at the Chemical Plant Site through an additional RI/FS.

Major accomplishments in FY 94 include:

- Completed characterization of site soil to support the foundation and contaminated soil removal work package;

- Completed the Quarry Residuals Work Plan in December 1993; and

- Completed the Draft Final Remedial Design Work Plan (Conceptual Design Report) for remedial action at the Chemical Plant Area of the Weldon Spring Site in April 1994.

\section{Progress in Conducting Remedial Actions}

Remedial actions accomplished during FY 94 include:

- Completed the building demolition packages at the Chemical Plant Area (a Removal Action);

- Demolished 15 buildings, for a total of 39 buildings demolished of the 44 buildings on site;

- Treated 19 million gallons of water at the Quarry Water Treatment Plant, and 33 million gallons at the Site Water Treatment Plant;

- Completed excavation of 43,259 cubic yards in the Quarry bulk waste removal effort, and transported waste to the Temporary Storage Area (approximately 35 percent of the total anticipated volume);

- Expanded operation of the Material Storage Area for temporary storage of materials taken from dismantled buildings;

- Completed design and initiated construction of the Pilot Sludge Processing Facility;

- Completed design and began construction of the Site Water Treatment Plant - Train 2 facilities;

- Demolished Imhoff Tank and removed Southeast Drainage Pipeline; and

- Raised and stabilized Pit 3 Berms and developed a Berm System Monitoring Program. 
Office:

Size:

NPL Status:

Mission:

\section{Overview of Environmental Conditions:}

CERCLA Funding in FY 94:
Oak Ridge Operations Office

12 acres (0.02 square mile)

Placed on the NPL on September 8, 1983

The Maywood Site, a privately owned site previously used for thorium extraction, was acquired by DOE in 1984. The site is managed under a Congressional mandate by DOE under the FUSRAP. The Maywood Site is used specifically for storage of radiologically contaminated materials resulting from remedial activities conducted on properties in the vicinity of the Maywood Site.

Onsite and offsite soil has been contaminated with radiological contaminants and associated chemicals. Approximately 57 remaining vicinity properties are radiologically contaminated.

\section{Progress in Reaching Interagency Agreement}

An FFA for the Maywood Site, signed by EPA Region II and DOE on July 23, 1990, became effective in April 1991. Schedules were subsequently negotiated for the DOE submittal of the RU, the baseline risk assessment, and the FS. EPA Region II reviewed and approved the package on November 25, 1991.

\section{Specific Cost Estimates and Budgetary Proposals Involved in Each Interagency Agreement}

Funds budgeted for environmental restoration under the FFA total $\$ 13.7$ million of appropriated funding for FY 95 and \$16.0 million for FY 96 according to the requested in the President's Budget. These budget figures do not, however, reflect the rescission that occurred in FY 95.

\section{Public Comments Regarding Interagency Agreements}

No new public comments regarding the FFA were received in FY 94. 


\section{Progress in Conducting Remedial Investigations/Feasibility Studies}

Significant progress was made in FY 94 on the completion of RI/FS activities at the site. The Final Draft FS Report was issued in April 1994. A draft Proposed Plan was developed and will be released to the public pending the resolution of specific issues.

\section{Progress in Conducting Remedial Actions}

Substantial progress has been made using removal actions. The site consists of the DOE-owned Maywood Interim Storage Site and vicinity properties, all of which are contaminated. As of May 1986, 25 of the vicinity properties were cleaned up using removal actions, and the resulting waste was placed in storage in the engineered cell at the Maywood Interim Storage Site. During FY 94, a dispute with EPA over cleanup criteria was resolved and agreement was reached with the State of New Jersey on the cleanup criteria for residential properties. In addition, subcontracts were awarded to begin removal of the Maywood Interim Storage Site Pile. Removal operations will begin in FY 95. 


\begin{tabular}{ll}
\hline Office: & Oak Ridge Operations Office \\
Size: & 7 acres $(0.01$ square mile) \\
NPL Status: & Placed on the NPL on September $21,1984$. \\
Mission: & $\begin{array}{l}\text { The Wayne Site, a privately owned site previously used for thorium } \\
\text { extraction, was acquired by DOE in } 1984 \text { under a Congressional } \\
\text { mandate and is managed by DOE under its FUSRAP. The Wayne Site } \\
\text { is used specifically as an interim storage site for contaminated material } \\
\text { removed during cleanup of the site and several vicinity properties. }\end{array}$ \\
$\begin{array}{l}\text { Overview of } \\
\begin{array}{l}\text { Environmental } \\
\text { Conditions: }\end{array}\end{array}$ & $\begin{array}{l}\text { Onsite and offsite soil contaminated by radiological and chemical } \\
\text { constituents. }\end{array}$ \\
$\begin{array}{l}\text { CERCLA Funding } \\
\text { in FY 94: }\end{array}$ & \begin{tabular}{l}
$\$ 3,495,000$ \\
\hline
\end{tabular}
\end{tabular}

\section{Progress in Reaching Interagency Agreement}

An FFA for the Wayne Site, signed by EPA on July 17, 1990 and by DOE on July 23, 1990, became effective in April 1991. Schedules were subsequently negotiated for the submittal of the RI, the baseline risk assessment, and the FS reports. EPA Region II reviewed and approved the package on November 25, 1991.

\section{Specific Cost Estimates and Budgetary Proposals Involved in Each Interagency Agreement}

Funds budgeted for environmental restoration under the FFA total $\$ 4.2$ million of appropriated funding for FY 95 and $\$ 6.1$ million for FY 96 according to the request in the President's Budget. These budget figures do not, however, reflect the rescission that occurred in FY 95.

\section{Public Comments Regarding Proposed Interagency Agreements}

No new public comments regarding the FFA were received in FY 94.

\section{Progress in Conducting Remedial Investigations/Feasibility Studies}

Significant progress was made during FY 94 on the completion of RI/FS activities at the site. To date, DOE has met all RI/FS milestones specified in the FFA. DOE continues to operate a public information center at the site to provide information on RU/FS progress. 
The RI report for the Wayne Site was issued in October 1993. The Baseline Risk Assessment Report was finalized in January 1994. The EPA Final Draft FS Report was issued in March 1994; a proposed plan was developed and will be released for public comment in FY 95.

\section{Progress in Conducting Remedial Actions}

Earlier removal actions at the site entailed removing waste from the vicinity properties and storing it in an engineered waste storage pile at the Wayne Interim Storage Site. Seven vicinity properties were remediated in 1993; the waste was shipped offsite. During FY 94, all remaining vicinity properties at the Wayne Site were remediated. 


\section{BROOKHAVEN NATIONAL LABORATORY}

Office:

Size:

NPL Status:

Mission:

\section{Chicago Operations Office}

5,300 acres ( 8.3 square miles)

Placed on the NPL on November 21, 1989.

Historically, the site was used by the U.S. Army as a post (called Camp Upton) during the First and Second World Wars. The Atomic Energy Commission was given title to the property in 1947 and subsequently transferred it to the Energy Research and Development Administration in 1975, which became DOE in 1977.

Brookhaven National Laboratory functions as a design, construction, and operations center for large research facilities such as particle accelerators, nuclear reactors and synchrotron storage rings for research in high-energy and nuclear physics, chemistry, biology, and energyrelated life and environmental sciences.

Groundwater and soil contamination.

CERCLA Funding in FY 94:

$\$ 9,401,000$

\section{Progress in Reaching Interagency Agreement}

DOE, EPA Region II, and the State of New York executed the IAG for Brookhaven National Laboratory on February 28, 1992. The effective date of the agreement was May 27, 1992. The IAG integrates both corrective action requirements under RCRA and response action requirements under CERCLA.

\section{Specific Cost Estimates and Budgetary Proposals Involved in Each Interagency Agreement}

Funds budgeted for environmental restoration under the IAG at the Brookhaven National Laboratory total \$13.4 million of appropriated funding for FY 95 and \$23.4 million for FY 96 according to the request in the President's Budget. These budget figures do not, however, reflect the rescission that occurred in FY 95.

\section{Public Comments Regarding Interagency Agreements}

No new public comments regarding the IAG were received in FY 94. 


\section{Progress in Conducting Remedial Investigations/Feasibility Studies}

In FY 94, DOE received approval from the regulators to combine some of the seven OUs for greater efficiency and cost-effectiveness. OUs II and VII were combined, as were OUs I and VI. Each of the five OUs will undergo an RI/FS. Six removal actions also have been identified. An annual schedule document is required under the IAG to be submitted to the regulators.

Field work for OU IV was completed in 1993 and the draft Remedial Investigation and Risk Assessment Reports were submitted to EPA Region II and the State of New York on May 25, 1994 for review and comment. The draft Work Plans for OUs V and III were submitted October 29, 1993 and June 30,1994, respectively, and were subsequently approved. Scoping activities were conducted for OU II/VII during FY 94 and Work Plan preparation began in August 1994.

Field work for OU I and the Spray Aeration was completed with the exception of the second round of groundwater sampling. The Work Plan for OU VI, which was prepared as an addendum to the OU I plans, was finalized in June 1994, and field work will be conducted in FY 95.

\section{Progress in Conducting Remedial Actions}

Four USTs were removed at Building 650 in August 1994, and a draft Completion Report was prepared. Characterization work for the Landfills Removal Action was completed, and a draft EE/CA was submitted to EPA Region II and the State of New York on July 28, 1994. Preparation of the design for the Current Landfills Cap began in FY 94, and the draft Design/Closure Report was submitted on July 25,1994 . A contractor was selected for the D Tanks removal action and mobilization occurred in July 1994. Dismantlement of the tanks started on September 14, 1994. Draft Designs for the Cesspool Removal Action were submitted in August 1994. The Building 464 soil removal action was completed in December 1993.

\section{Enforcement Activities}

A $\$ 100,000$ assessment of penalties under RCRA/Toxic Substances Control Act (TSCA) was pending throughout 1992 and 1993. A settlement of $\$ 62,000$ was reached in the spring of 1994. On May 11, 1994, DOE, EPA, and the operating contractor (Associated Universities Incorporated) signed an agreement on the penalty, which also included preparation of a Wildlife Survey and Management Plan and an internal audit of the hazardous waste management system. These activities are expected to be completed in FY 95. 
Office:

Size:

NPL Status:

Mission:

Overview of Environmental Conditions:

CERCLA Funding in FY 94:
Ohio Field Office Project

1,050 acres ( 1.6 square miles)

Placed on the NPL on November 21, 1989.

The Fernald Environmental Management Project (FEMP), formerly the Feed Materials Production Center, was constructed in the early 1950s and was used to produce uranium metal products for use by the Government. Production was suspended in July 1989. The site was placed under the Office of Environmental Management (EM) effective October $1,1990$.

Soil and groundwater contamination by radionuclides above background levels both onsite and in adjacent offsite areas. Release of radon and the retention of large quantities of low-level radioactive and mixed wastes in onsite storage areas are also of significant concern.

\section{Progress in Reaching Interagency Agreement}

At the time when FEMP was placed on the NPL, the site was engaged in activities aimed at compliance with the terms of an existing Federal Facility Compliance Agreement signed on July 18, 1986 between DOE and EPA Region V. The CERCLA portion of the Federal Facility Compliance Agreement was replaced by the signing of a Consent Agreement (an IAG) with EPA on April 9, 1990, which became effective on June 29, 1990. The Consent Agreement provides for the execution of RI/FSs for five OUs and the performance of removal and remedial actions at the facility. DOE and EPA signed an Amended Consent Agreement which was executed on September 20, 1991. The amended Consent Agreement revised the milestones for submittal of RI/FS documents to EPA and expanded the scope of the RI/FS to the former production area. The Amended Consent Agreement was modified in April 1993 as a result of an informal settlement concerning OU 2 schedules.

\section{Specific Cost Estimates and Budgetary Proposals Involved in Each Interagency Agreement}

Funds budgeted for environmental restoration under the Amended Consent Agreement at the FEMP total \$257.7 million of appropriated funding for FY 95 and \$256.3 million for FY 96 according to the 
request in the President's Budget. These budget figures do not, however, reflect the rescission that occurred in FY 95.

\section{Public Comments Regarding Interagency Agreements}

No new public comments regarding the Consent Agreement were received in FY 94.

\section{Progress in Conducting Remedial Investigations/Feasibility Studies}

The RI/FS process at the FEMP was initiated in July 1986 under the provisions of a 1986 Federal Facility Compliance Agreement. The 1990 CERCLA 120 and 106 Consent Agreement amended the CERCLA portion of the 1986 agreement and restructured the ongoing investigations into five distinct OUs. The 1991 Amended Consent Agreement revised the milestones for submittal of RI/FS documentation to EPA for five OUs, whereby separate RI/FS reports and RODs would be issued for each of the OUs. Additionally, the Amended IAG established milestone dates for the submittal of select documents addressing all five OUs and a final combined site-wide OU. Progress in completing the RI/FS for each of the five OUs as defined under the provisions of the Amended Consent Agreement (as modified in April 1993) is summarized below.

\section{Affecting All OUs}

The Amended IAG provided for the submittal of a risk assessment work plan to establish the specific approach, parameters, and models to be employed to conduct OU baseline and FS risk assessments. Approval of this work plan was received from EPA in May 1992. A site-wide characterization report, required by the agreement, providing a preliminary site-wide baseline assessment was transmitted to EPA in August 1992. This report is being finalized. A site-wide CERCLA quality assurance plan pertaining to all facility sampling and analysis was approved by EPA in September 1992. This plan integrates DOE and EPA quality assurance policies and principles.

\section{OU 1: Waste Storage Area}

This OU comprises the existing six FEMP waste pits, the Clearwell, the Burnpit, berms, liners, and soil within the OU boundary. The initial Screening of Alternatives Report was approved by EPA in January 1991. The final RI Report was submitted to EPA in February 1994 and, following comment resolution and incorporation, was approved by EPA in August 1994. The OU draft 1 FS Report and Proposed Plan (PP) were submitted to EPA in March 1994. The Final Draft FS Report and PP were approved by EPA in August 1994. The PP was released for review by the public in August 1994 and a Public Hearing on the PP was held in August 1994. The Draft ROD for OU I was submitted to EPA in November 1994, and the Final ROD is expected to be executed by EPA in March 1995.

\section{OU 2: Other Waste Units}

This OU comprises the FEMP solid waste landfill, water treatment lime sludge ponds, fly ash piles, and south field area. Site investigation activities within this unit included the completion of geophysical surveys, collection of representative waste and leachate samples from each waste unit and the completion of over 25 wells in the vicinity of the waste units.

In accordance with the April 1993 revisions to the Amended Consent Agreement, the OU 2 revised draft RI report was submitted to EPA and Ohio in February 1994, and the draft FS/PP was submitted in August 1994. A formal public comment period began on October 26 and ended on 
November 25,1994 . A request to extend the public comment period was received on November 2, 1994. The Ross Township Board of Trustees formally requested a 30-day extension to the public comment period in order to allow additional time for the public to review the Proposed Plan for Remedial Actions at Operable Unit 2. A request to delay the milestone submission date for the draft ROD and Responsiveness Summary from the January 5, 1995 date to February 1995 will be forwarded to the EPA and Ohio for approval.

\section{OU 3: Production Area and Production-Associated Facilities}

This OU comprises the FEMP former Production Area and production-associated facilities and equipment (including all above- and below-grade improvements), including but not limited to all structures, equipment, utilities, drums, tanks, solid waste, waste products, thorium, effluent lines, K-65 transfer line, wastewater treatment facilities, fire training facilities, scrap metal piles, feed stock and coal piles. The Interim ROD to decontaminate and dismantle the facilities in OU 3 was approved by EPA in July 1994. A combined RI/FS/PP for OU 3 is scheduled for submittal to EPA in September 1995. The Final ROD is scheduled for submittal to EPA in July 1996.

OU 4: Silos 1,2,3 and 4

This OU comprises the four waste storage silos located in the FEMP waste storage area. The Initial Screening of Alternatives Report was approved by EPA in October 1990. The final RI report was submitted to EPA for approval in October 1993 and was approved in November 1993. The field investigations in support of the OU $4 \mathrm{RI}$ and FS reports have been completed and the data have been incorporated into the OU 4 FS. The draft final OU 4 FS/PP was resubmitted to the EPA and Ohio in December 1993 after being disapproved in November 1993. The OU 4 FS/PP was conditionally approved in February 1994. The Responsiveness Summary was distributed to all individuals and agencies that commented on the FS/PP, as well as all other interested parties, in September 1994.

\section{OU 5: Environmental Media}

This OU comprises groundwater, surface water, soil, sediments, and flora and fauna in the vicinity of the FEMP not included in the definition of OUs 1 through 4. The Initial Screening of Alternatives Report was submitted to EPA in November 1992 and was conditionally approved in January 1993. EPA comments were incorporated and the Initial Screening of Alternatives was resubmitted to EPA in March 1993. A treatability study work plan was approved by EPA in September 1992. Treatability studies were initiated in August 1992. The RI report was submitted to EPA in June 1994. Comments were received in September 1994. The FS Report is nearing completion and will be submitted to EPA for review in the latter part of 1994. The ROD is scheduled for submittal to EPA in July 1995

\section{Progress in Conducting Remedial Actions}

Current site activities focus on completion of the RI/FSs. Final remedial actions will be initiated following completion of the RI/FSs and signing of RODs. Several removal actions, however, are planned or underway. Consistent with the Amended Consent Agreement, 27 specific Removal Actions were identified as part of the amended FFA and are in various stages. 


\section{Removal Actions}

Of the 22 Removal Actions that were ongoing in FY 93 (and detailed in the FY 93 Report to Congress), two were completed in FY 93 and one was superseded by an Interim ROD for OU 3. The status of the 19 remaining Removal Actions is summarized in Table III-1.

In summary, of the 19 Removal Actions for which activity occurred in FY 94, 13 are ongoing (including those partially completed) and six were completed in FY 94.

\section{Enforcement Activities}

On December 16, 1992, EPA and the Ohio Environmental Protection Agency disapproved the draft RI Report for OU 2, pending the resolution of extensive comments. All parties agreed that additional field sampling was needed to adequately characterize OU 2 and to address the comments. The regulators held that while DOE had fulfilled the scope of the approved OU 2 Work Plan and had conducted additional sampling, the objectives of the plan had not been met. DOE proposed revised schedules to accommodate the necessary sampling. The regulators determined that "good cause" did not exist for an extension.

During informal dispute resolution, an agreement was reached in early April 1993 which included the following provisions: OU 2 schedules are revised to reflect additional field sampling; RODs for three other OUs are each accelerated by 1 month; DOE will spend $\$ 2$ million on a supplemental environmental project intended to further reduce uranium releases to the Great Miami River; EPA assessed a $\$ 50,000$ stipulated penalty payable by DOE under the terms of the Amended Consent Agreement; and if DOE misses the revised milestone for the OU 2 ROD, an additional $\$ 25,000$ stipulated penalty may be automatically assessed. 
Table III-1. Status of FEMP Removal Actions

\begin{tabular}{|c|c|c|}
\hline $\begin{array}{l}\text { REMOVAL } \\
\text { NO. }\end{array}$ & NAME & ACTIVITIES \\
\hline 1 & $\begin{array}{l}\text { Contaminated Water } \\
\text { Under FEMP } \\
\text { Buildings }\end{array}$ & $\begin{array}{l}\text { The objective of this Removal Action is to pump perched water beneath Plants } 2,3,6,8 \text {, and } 9 \text {, with } \\
\text { subsequent treatment in the Plant } 8 \text { VOC Treatment System. Current activities include treatment of the } \\
\text { perched water in this VOC treatment system. }\end{array}$ \\
\hline 3 & $\begin{array}{l}\text { South Groundwater } \\
\text { Contamination Plume }\end{array}$ & $\begin{array}{l}\text { The Removal Action is subdivided into five parts: 1) provision of an alternate water supply to an } \\
\text { affected industrial user, 2) installation of a pump and discharge system for South Plume groundwater, } \\
\text { 3) construction and operation of Interim Advanced Waste Water Treatment systems, 4) South Plume } \\
\text { groundwater monitoring and installation of homeowner treatment systems, and 5) groundwater } \\
\text { modeling and geotechnical investigations. Parts } 1,2 \text {, and } 3 \text { were completed prior to FY 93. Part 4, } \\
\text { which includes sampling of private homeowner and existing RI/FS wells in the South Plume area, } \\
\text { continues. In addition, as part of the OU } 2 \text { dispute resolution with EPA, DOE agreed to install a South } \\
\text { Plume Interim Treatment system for partial treatment of South Plume discharge water to further reduce } \\
\text { uranium discharge to the Great Miami River. Installation was completed and operation commenced in } \\
\text { March 1994. Part } 5 \text { field activities were completed in February } 1994 \text {. }\end{array}$ \\
\hline 5 & K-65 Decant Sump & $\begin{array}{l}\text { The objective of this Removal Action requires the removal of sludge and liquid from the K-65 Decant } \\
\text { Sump Tank. The tank has been accumulating liquid since it was emptied in } 1991 \text {. Once the tank is } 80 \\
\text { percent full, repumping is required. Current activities include monitoring the liquid level and } \\
\text { performing maintenance as needed. }\end{array}$ \\
\hline 7 & $\begin{array}{l}\text { Plant } 1 \text { Pad } \\
\text { Continuing Releases }\end{array}$ & $\begin{array}{l}\text { This Removal Action consists of three stages. Stage } 1 \text { required the implementation of run-on/off } \\
\text { control measures and was completed in January } 1992 \text {. Stage } 2 \text { required the installation of } 80,000 \\
\text { square feet of a newly covered and controlled concrete storage pad and was completed in December } \\
1992 \text {. Stage } 3 \text { involves activities to upgrade the remaining } 375,000 \text { square feet of the existing Plant } 1 \\
\text { storage pad. Stage } 3 \text { activities are ahead of schedule and are currently ongoing. }\end{array}$ \\
\hline 9 & $\begin{array}{l}\text { Removal of Waste } \\
\text { Inventories }\end{array}$ & $\begin{array}{l}\text { FEMP procedures for the Removal of Waste Inventories were submitted to EPA in August } 1991 \text {. } \\
\text { These procedures detail the methods used in packaging and shipment of low-level waste, including } \\
\text { thorium, from the FEMP. Updated procedures were approved by EPA in October 1992. Removal } \\
\text { No. } 9 \text { will continue through issuance of the OU } 3 \text { ROD. During January 1994, 3,554 drum equivalents } \\
\text { of low-level waste were dispositioned. There were 78,000 drum equivalents of low-level waste } \\
\text { disposed of in FY } 94 \text {. }\end{array}$ \\
\hline
\end{tabular}


Table III-1. Status of FEMP Removal Actions (Continued)

\begin{tabular}{|c|c|c|}
\hline $\begin{array}{l}\text { REMOVAL } \\
\text { NO. }\end{array}$ & NAME & ACTIVITIES \\
\hline 12 & Safe Shutdown & $\begin{array}{l}\text { Safe shutdown procedures were submitted to EPA on October } 30,1991 \text {. Updated procedures were } \\
\text { approved by EPA in October } 1992 \text {. These procedures detail the methods to be used to place the former } \\
\text { production facilities at the FEMP into a safe and permanent shutdown configuration. Field work began } \\
\text { in May } 1993 \text { and is expected to be completed in FY } 95 \text {. }\end{array}$ \\
\hline 13 & Plant 1 Ore Silos & $\begin{array}{l}\text { The objective of this Removal Action is to dismantle the } 14 \text { Plant } 1 \text { Ore Silos and their support } \\
\text { structures. Demolition of the concrete silos began in February 1994. A new design approach is being } \\
\text { evaluated which would allow for quicker dismantlement of the silos. }\end{array}$ \\
\hline 14 & $\begin{array}{l}\text { Contaminated Soils } \\
\text { Adjacent to Sewage } \\
\text { Treatment Plant } \\
\text { Incinerator }\end{array}$ & $\begin{array}{l}\text { The objective of this Removal Action was to identify and possibly remove contaminated soils near the } \\
\text { Sewage Treatment Plant Incinerator. The removal action work plan was approved by EPA in } \\
\text { May 1992. Progressive site activities identified significantly larger volumes of contaminated materials } \\
\text { than originally planned. A work plan addendum addressing these changed site conditions was } \\
\text { submitted to EPA in January 1993. EPA approval was received in August } 1993 \text {, and the Removal } \\
\text { Action was completed in February 1994. }\end{array}$ \\
\hline 15 & Scrap Metal Piles & $\begin{array}{l}\text { The objective of this Removal Action is to contract for metals decontamination and subsequently reuse, } \\
\text { recycle, or dispose of existing FEMP Scrap Metal Piles. The removal action work plan was approved } \\
\text { by EPA in May 1992. Removal of the ferrous metals was completed in March 1994. The Project Plan } \\
\text { for removal of copper was submitted to EPA in September } 1994 \text {. }\end{array}$ \\
\hline 17 & $\begin{array}{l}\text { Improved Storage of } \\
\text { Soil and Debris }\end{array}$ & $\begin{array}{l}\text { The objective of this Removal Action is to improve the soil and debris storage locations at the site by } \\
\text { providing run-off controls and covered structures. The Removal Action work plan was approved by } \\
\text { EPA in October 1992. Field work is ongoing. }\end{array}$ \\
\hline 18 & $\begin{array}{l}\text { Control Exposed } \\
\text { Material in Pit } 5\end{array}$ & $\begin{array}{l}\text { The objective of this Removal Action was to control or mitigate any potential fugitive dust emissions } \\
\text { from Pit } 5 \text { by covering all material in the pit. Construction activities in this Removal Action associated } \\
\text { with resubmerging pit material concluded in December 1992; construction activities associated with } \\
\text { berm repairs concluded in June 1993. A Removal Action Final Report was forwarded to EPA in } \\
\text { October } 1993 \text {. }\end{array}$ \\
\hline 19 & $\begin{array}{l}\text { Decontamination and } \\
\text { Dismantling of } \\
\text { Plant } 7\end{array}$ & $\begin{array}{l}\text { The objective of this Removal Action is to mitigate potential fugitive dust releases from Plant } 7 \text { by the } \\
\text { decontamination and dismantling of the facility. The Removal Action work plan was approved by EPA } \\
\text { in July 1993. Mobilization began in February } 1994 \text {. }\end{array}$ \\
\hline
\end{tabular}


Table III-1. Status of FEMP Removal Actions (Continued)

\begin{tabular}{|c|c|c|}
\hline $\begin{array}{l}\text { REMOVAL } \\
\text { NO. }\end{array}$ & NAME & ACTIVITIES \\
\hline 20 & $\begin{array}{l}\text { Stabilization of } \\
\text { Uranyl Nitrate } \\
\text { Hexahydrate (UNH) } \\
\text { Inventories }\end{array}$ & $\begin{array}{l}\text { The objective of this Removal Action is to process the FEMP inventory of } 200,000 \text { gallons of uranyl } \\
\text { nitrate hexahydrate into a solid, nonleachable form. Processing was initiated in July } 1992 \text { but was } \\
\text { subsequently suspended due to safety concerns and the need to upgrade the treatment system. The } \\
\text { project is undergoing safety and operational readiness reviews. }\end{array}$ \\
\hline 22 & $\begin{array}{l}\text { Waste Pit Area } \\
\text { Containment } \\
\text { Improvement }\end{array}$ & $\begin{array}{l}\text { This Removal Action improved erosion control measures to mitigate releases to surface water and air } \\
\text { from contaminated soils in the FEMP Waste Pit Area. Field activities were initiated in October 1992, } \\
\text { construction activities were completed in June 1993, and the Removal Action Final Report was sent to } \\
\text { EPA in October 1993. }\end{array}$ \\
\hline 24 & $\begin{array}{l}\text { Removal of the Pilot } \\
\text { Plant Sump }\end{array}$ & $\begin{array}{l}\text { The objective of this Removal Action was to eliminate potential releases from the Pilot Plant Sump by } \\
\text { cleanup and removal of the system. The Removal Action Work Plan was approved by EPA } \\
\text { in February 1993. The Removal Action was completed on December } 20,1993 \text {. }\end{array}$ \\
\hline 25 & $\begin{array}{l}\text { Cleanup of Nitric } \\
\text { Acid Tank Car and } \\
\text { Surrounding Area } \\
\end{array}$ & $\begin{array}{l}\text { The objective of this Removal Action was to decontaminate an existing rail car containing nitric acid } \\
\text { and address any adjacent soils contamination. The Removal Action Work Plan was approved by EPA } \\
\text { on March } 9,1993 \text {. The Removal Action was completed in FY } 94 \text {. }\end{array}$ \\
\hline 26 & Asbestos Removals & $\begin{array}{l}\text { The objective of this Removal Action is to mitigate the potential for fugitive releases of asbestos. A } \\
\text { compendium of procedures supporting this Removal Action was submitted to EPA in May } 1992 . \\
\text { Activities include small- and large-scale in-situ repairs, encasement, encapsulation, and removals. } \\
\text { Fieldwork is ongoing. }\end{array}$ \\
\hline 28 & $\begin{array}{l}\text { Contamination of the } \\
\text { Fire Training Facility }\end{array}$ & $\begin{array}{l}\text { The objective of this Removal Action is to address the removal, decontamination and disposal, or } \\
\text { storage of all tanks, equipment, the underground sump and oil/water separator, in addition to addressing } \\
\text { "hot spot" soil staining and other surface soils from which a threat of migration of contaminants exists. } \\
\text { The proposed action was submitted to EPA in January 1993. The final work plan was submitted to } \\
\text { regulators in February 1994. The scheduled completion date of the project is July } 1995 \text {. }\end{array}$ \\
\hline 29 & $\begin{array}{l}\text { Inactive Fly Ash Pile } \\
\text { Erosion Control }\end{array}$ & $\begin{array}{l}\text { The objective of this emergency response action was to mitigate the observable bank erosion that is } \\
\text { taking place adjacent to Paddy's Run. Field work was initiated in April } 1993 \text { and was completed by } \\
\text { the end of May 1993. The final report was submitted to EPA in April } 1994 \text { for review. }\end{array}$ \\
\hline
\end{tabular}


This Page Intentionally Left Blank. 
Office:

Size:

NPL Status:

Mission:

Overview of Environmental Conditions:

CERCLA Funding in FY 94:
Albuquerque Operations Office

306 acres ( 0.5 square mile)

Placed on the NPL on November 21, 1989.

The Mound Plant has been in continuous use since 1948. Its main mission was to manufacture non-nuclear components and tritiumcontaining components for nuclear weapons that are assembled at another site. Other activities include the separation, purification, and sale of stable isotopes of the noble gases; solar energy; fossil fuels; nuclear safeguards; waste management; heat source testing (plutonium); and fusion fuel systems. In 1994, the primary mission changed to environmental management and economic development.

Tritium and volatile organic compound contamination of onsite and offsite groundwater and soils contaminated with residual plutonium from past onsite operations.

\section{Progress in Reaching Interagency Agreement}

DOE and EPA Region V executed an FFA on August 6, 1990. The State of Ohio expressed an interest in developing a three-party agreement, with the State of Ohio being added to the FFA. Negotiations were held on the development of the new three-party FFA, which were culminated by the signing of this new agreement on July 15, 1993. The State of Ohio continued its involvement in the monthly project management meetings and document reviews just as it had even before the new FFA was signed.

\section{Specific Cost Estimates and Budgetary Proposals Involved in Each Interagency Agreement}

Funds budgeted for environmental restoration under the FFA total $\$ 15.4$ million of appropriated funding for FY 95 and $\$ 23.7$ million for FY 96 according to the request in the President's Budget. These budget figures do not, however, reflect the rescission that occurred in FY 95. 


\section{Public Comments Regarding Interagency Agreements}

Prior to FY 93, limited public comments were received on the original 1990 FFA. Most of those comments inquired why the site was placed on the NPL. Limited comments were received during the FY 93 comment period for the new three-party FFA (no formal comment period in FY 94). EPA Region V, the State of Ohio, and DOE evaluated these comments and determined that no modifications to the FFA were required.

\section{Progress in Conducting Remedial Investigations/Feasibility Studies}

The Mound Plant originally was divided into nine OUs that separated the plant into discrete geographical units. OU 7 (Limited Action Sites) and OU 8 (Underground Tanks) had previously been closed out as needing no further action. OU 3 (Miscellaneous Sites) was closed out in 1993 as needing no further action. A few individual sites in OU 3 which require more characterization were transferred to either OU 2 (Main Hill Seeps) or OU 5 (South Property) for future investigation.

During FY 93, RI field work was completed in OU 1 (Area B/Groundwater), and the RI report was submitted in November 1993. The FS was initiated and will be finalized in FY 95. OU 9 (Site-Wide and Offsite) continues its assessment activities including residential well sampling, regional soils sampling, surface water and sediment sampling, seismic refraction studies, ecological surveys, and wetlands determinations. The OU 2 RI work plan and sampling and analysis plan were completed. Phase I, site reconnaissance, was completed in FY 94. The OU 5 RI work plan was finalized in December 1993. Sampling activities were completed in FY 94 for the New Property. A portion of the New Property was declared clean and has been proposed for transfer to the City of Miamisburg. Phase I sampling was completed during FY 94 for the operational area of OU 5. Verification of soil sites cleaned under the Mound Decommissioning program continued in OU 6.

\section{Progress in Conducting Remedial Actions}

Implementation of three removal actions was initiated for the B Building Solvent Storage Shed, the Firefighter Training Pit, and Area 7 tank removal. The B Building solvent shed has been dismantled, and a soil vapor extraction system was installed and operated to remove VOCs from the soil. Over 100 pounds of VOCs were removed from the soil in FY 94. Bioremediation will be used to remediate diesel-contaminated soil from the firefighting training pit. The OU 4 removal action design will be started in January 1995. The first ROD on OU 1 is scheduled for completion in FY 95. No immediate health risks have been identified to date based on information available for the approximately 125 known potential release sites. Dismantlement of the outer shell of the Special Metallurgical Building was initiated in FY 94. Some 200,000 pounds of metal have been shipped offsite for recycling. Removal of contaminated soil from the Special Metallurgical Leach Field was continued in FY 94. One underground line and its associated contaminated soil were removed in FY 94. A total of 445 boxes of soil were shipped to Nevada Test Site for disposal. 
Office:

Size:

NPL Status:

Mission:

Overview of

Environmental

Conditions:

CERCLA Funding

in FY 94:
Savannah River Operations Office

Approximately 192,000 acres (300 square miles)

Placed on the NPL on November 21, 1989.

The Savannah River Site (SRS) is located in south-central South Carolina, approximately 25 miles southeast of Augusta, Georgia and 20 miles south of Aiken, South Carolina. The site encompasses 352 square miles and is bordered by the Savannah River on the southwest.

Although SRS's primary mission over the past 40 years focused on the production of nuclear materials (primarily tritium and plutonium) for national defense, the site's nuclear production reactors have not operated since 1988. R Reactor was shut down permanently in 1964, and C Reactor was placed in cold standby in 1987 . K, $P$, and $L$ reactors were shut down in 1988 for maintenance and safety upgrades and have never been restarted. As a result, much of the site's mission has turned to environmental restoration and waste management activities. The current program consists of 419 inactive waste and groundwater sites and an estimated 660 facilities that are candidates for decommissioning.

Onsite soil, groundwater and air emissions associated with chemical and radioactive releases.

$\$ 31,445,000$

\section{Progress in Reaching Interagency Agreement}

DOE, EPA Region IV, and the State of South Carolina negotiated an IAG for SRS during calendar years 1990 through 1992. The IAG was executed on January 15, 1993 and became effective on August 16, 1993.

\section{Specific Cost Estimates and Budgetary Proposals Involved in Each Interagency Agreement}

Funds budgeted for environmental restoration under the IAG total $\$ 31.6$ million of appropriated funding for FY 95 and $\$ 65.8$ million for FY 96 according to the request in the President's Budget. These budget figures do not, however, reflect the rescission that occurred in FY 95. 


\section{Public Comments Regarding Interagency Agreements}

The IAG Notice of Intent was signed on December 2, 1991. The document was released for 60-day public review on December 17, 1991; the public comment period ended on February 14, 1992. A public meeting was held on January 23, 1992. Significant public comments focused on the specific roles and jurisdictions of the South Carolina Department of Health and Environmental Control (SCDHEC) and EPA Region IV in maintaining and enforcing DOE SRS cleanup actions.

The public comments also included concerns that the IAG should not limit SCDHEC's RCRA authority. The IAG was revised to better clarify dispute resolution procedures and authorities of the two regulators for oversight of RCRA and CERCLA cleanup activities.

Additionally, public comments showed the need to revise SRS' system of prioritizing waste units. The IAG was revised to include a priority system recommended by EPA, and a responsiveness summary addressing public comments was issued in 1993.

Comments requesting a site advisory board consisting of members of the public were addressed in a revised public involvement plan. SRS has developed a site-specific advisory board, the Citizens Advisory Board, which began functioning in 1994.

\section{Progress in Conducting Remedial Investigations/Feasibility Studies}

A RCRA 3004(u) permit was issued by EPA Region IV and the State of South Carolina on September 29, 1987. A program plan, which outlines the requirements for the preparation of unitspecific investigation plans and proposed plans, was revised on August 20, 1993. The following activities were accomplished during FY 94:

- $\quad$ Submitted two RFI/RI Plans;

- $\quad$ Signed two final remedial RODs;

- Submitted two Baseline Risk Assessments;

- Completed field characterization sampling and began data analysis at nine waste sites;

- Initiated or continued field sampling at eight waste sites;

- $\quad$ Completed site screening/evaluation at 24 additional sites and submitted 24 site Evaluation Reports;

- Completed monitoring wells and well points defining plume conditions at Sanitary Landfill groundwater unit;

- Completed field sampling and began data analysis on the F \& H Area Groundwater Operable Unit;

- Began implementation of the Field Investigation Plan at the Mixed Waste groundwater unit and Burial Ground Complex; 
- $\quad$ Submitted revised RCRA closure plans for the Acid-Caustic Basins, Savannah River Laboratory Seepage Basins, Sanitary Landfill, and Low Level Radioactive Waste Disposal Facility;

- Submitted Proposed Plans (three Interim Remedial and four Remedial) for seven CERCLA sites for which approvals and/or Records of Decision are expected in FY 94/95;

- $\quad$ Submitted the F \& H Area Groundwater Operable Unit Proposed Plans to EPA and SCDHEC for review; and

- Submitted the Corrective Action Plan for Mixed Waste Management Facility groundwater unit to SCDHEC

\section{Progress in Conducting Remedial Actions}

The following activities were accomplished in FY 94

- Completed six removal actions;

- Initiated fabrication and field construction of four vadose zone units to clean groundwater in A/M Area;

- Completed procurement and construction of A-2 air stripper to clean groundwater in $\mathrm{A} / \mathrm{M}$ Area;

- $\quad$ Reached 2-billion-gallon mark in groundwater cleanup in A/M Area, with more than 323,000 pounds of solvents removed;

- $\quad$ Completed Remedial Actions at seven waste sites;

Completed Interim Actions at 13 additional waste sites;

Initiated Sanitary Landfill foundation layer construction to prepare for remediation;

Began Burial Ground Complex drainage system construction and completed sedimentation basins;

- Designed and procured an M-1 stripper air abatement system to treat organics from groundwater remediation system;

- Completed startup and began operation of the Purge Water Disposal Facility to treat monitoring well water; and

Completed surface enhancements at $F \& H$ Area basins to further reduce contamination to groundwater aquifer. 
This Page Intentionally Left Blank. 
OAK RIDGE RESERVATION

(Oak Ridge National

Laboratory; Y-12 Plant;

K-25 Site [Oak Ridge Gaseous

Diffusion Plant]; and Oak

Ridge Associated Universities)

Office:

Size:

NPL Status:

Mission:

Overview of

Environmental

Conditions:

\section{CERCLA Funding} in FY 94:
Oak Ridge Operations Office

37,000 acres (57.8 square miles)

Placed on the NPL on November 21, 1989

The Oak Ridge National Laboratory (ORNL) provides extensive research and development in energy production. Activities include reactor and accelerator development and operation, production and sale of radioactive and stable isotopes, and environmental and health research.

The K-25 Site (the Oak Ridge Gaseous Diffusion Plant) was a production and development facility for uranium enrichment. Production operations at the K-25 Site were shut down in 1985. The present mission of the K-25 Site is environmental restoration, decommissioning, waste management, and support for other government agencies in the Work for Others program.

The Y-12 Plant's original mission was to separate the fissionable isotope of uranium- 235 by the electromagnetic process. The plant today has four principal missions: to dismantle nuclear weapon components; to provide special production support to DOE programs; to support ORNL research programs; and to serve as a manufacturing, technology, and demonstration center.

The Oak Ridge Associated Universities (ORAU) is a private, not-forprofit association of 49 colleges and universities. It is a contractor to DOE, conducting research and education programs in the areas of energy, health, and the environment for DOE, ORAU's member institutions, and other private and government organizations.

The sites include waste units that are either radioactive, hazardous, mixed (both radioactive and hazardous), or non-radioactive/nonhazardous. Examples of the concerns include radioactive underground tanks, solid waste disposal areas, liquid waste pit and trenches, hydrofracture facilities, and dense, non-aqueous phase liquid migration in fractured rock. More than 400 contaminated units exist at the reservation, and surface water and groundwater also are contaminated. 


\section{Progress in Reaching Interagency Agreement}

DOE, EPA Region IV, and the State of Tennessee have negotiated an IAG for the following sites included within the Oak Ridge Reservation (ORR): ORNL, Y-12 Plant, K-25 Site, ORAU, and the Clinch River. The IAG was effective on January 1, 1992. In accordance with the IAG, the ORR is currently integrating the requirements of corrective measures under RCRA and applicable state law with response actions under CERCLA.

\section{Specific Cost Estimates and Budgetary Proposals Involved in Each Interagency Agreement}

Funds budgeted for environmental restoration under the IAG at the ORR total \$211.9 million of appropriated funds for FY 95 and $\$ 170.9$ million for FY 96 according to the request in the President's Budget. These budget figures do not, however, reflect the rescission that occurred in FY 95.

\section{Public Comments Regarding Interagency Agreements}

The public comment period for the IAG closed on February 25, 1991. No comments were received. No new public comments regarding the IAG were received in FY 94.

\section{Progress in Conducting Remedial Investigations/Feasibility Studies}

To address contamination of the ORR as a whole, the reservation has been partitioned into 54 OUs consisting of source control OUs and integrator OUs (such as groundwater and surface water), which can be prioritized to achieve the most effective and rapid investigation and cleanup possible. OUs are redefined and work schedules are adjusted as investigations progress and new data become available. RI/FSs are being conducted for each OU. Removal actions and interim remedial actions are conducted, where appropriate, to address threats to human health and the environment in advance of the final remedial action selection.

The remedial action work plans, site characterization studies, RI reports, and remedial design work plans have been prepared, using EPA guidelines for CERCLA RI/FSs and RCRA RFIs where appropriate. These documents were sent out in accordance with milestones specified in the negotiated IAG and the schedule defined in the RCRA permit. Public meetings were held during the year to advise the public of the restoration process being implemented to remediate the ORR and to address the public's concerns over the relative risk associated with the offsite contamination. Work completed or under way during FY 94 includes:

- K-25 Site - submittal of one Draft RI Report, repacking of over 21,000 pond waste management project drums, and completion of geophysical logging of 74 existing bedrock monitoring wells;

- ORAU - submittal of one RI Work Plan/SI Report and completion of RI and SI field activity (RI/FS approval expected March 1995);

- ORNL - submittal of one RI/FS Report for the Gunite Tanks; submittal of one Site Characterization Work Plan for WAG 1 Groundwater; approval of two Interim RODs at WAG 11 White Wing Scrap Yard and WAG 13 Cesium Plot Removal; submittal and approval of an engineering evaluation/cost analysis to reduce contaminant flux from WAG 1 Corehole 8 and WAG 5 Seeps; submittal of three Treatability Study Work Plans for WAG 1 Gunite 
Tanks, WAG 7 Pit 1 In-situ Vitrification, and WAG 11 PCB Destruction; submittal of two Proposed Plans;

- Y-12 Plant - submittal of three RI reports, two FS Reports, one PP, one ROD, and two PostConstruction Reports to EPA and the state for approval; and

- ORR (offsite) - submittal and approval of plan to separate Clinch River and Watts Bar OU into two separate remedial actions to streamline the remediation process; submittal of an RI/FS Report for Lower East Fork Poplar Creek; and, submittal of an RI/FS Report and PP for Lower Watts Bar.

Additional work underway includes:

- K-25 Site - initiation and 60 percent completion of construction of K-1407 B and C Ponds; initiation of collection of the SW31 Seep;

- ORNL - initiation of sampling Gunite Tanks for treatability study; completion of facility characterization and demolition alternatives assessment for Waste Evaporator Facility and Fission Product Pilot Plant; completion of preliminary investigation on the Molten Salt Reactor Experiment Fuel Migration; construction of artificial wetland test cells at South Campus Facilities and initiation of testing for degradation of trichloroethylene in groundwater;

- Y-12 Plant - completion of three RCRA closures including Kerr Hollow Quarry; determination of No Further Action from characterization of the Upper East Fork Poplar Creek OU 2 Abandoned Nitric Acid Pipeline Project; and

- ORR (offsite) - determination of No Further Action for Freels Bend area OU; completion of the Pilot Treatment Demonstration on the Lower East Fork Poplar Creek soils; completion of sampling of sediment and water of the Clinch River/Poplar Creek OU; analysis of regional gravel aquifer levels for mercury within the Lower East Fork Poplar Creek soils and their influence on selecting the appropriate removal action alternative.

\section{Progress in Conducting Remedial Actions}

Final CERCLA remedial action will be initiated after RODs are signed. Removal and interim cleanup actions completed or underway during FY 94 include:

- $\quad$ K-25 Site - completion of K-1070 Spring - Phase 1 Interim Action;

- $\quad$ ORNL - completion of Interim ROD cleanup activities and postconstruction reports for WAG 11 White Spring Scrap Yard and WAG 13 Cesium Plots Removal; completion of Decision Documents on WAG 5 Seeps and WAG 6; completion of Removal Action Design for WAG 5 Seeps;

- Y-12 Plant - completion of Interim Removal of mercury-contaminated sediments from the Reduction Mercury Project Effluent Tanks and two Interim ROD cleanup activities; and

- ORR (offsite) - completion of Atomic City Auto Parts, CSX Railroad, and Solway Drum removal actions. 
In addition, the ORR accomplished numerous community relations efforts during FY 94. These include:

- $\quad$ Conducted an environmental fair;

- $\quad$ Organized a stakeholder/site-specific advisory board;

- Developed a citizen working group for East Fork Poplar Creek;

- $\quad$ Conducted 40 public meetings/workshops; and

- Conducted a Common Ground Future Land Use Process Seminar. 
Office:

Size:

NPL Status:

Mission:

Overview of

Environmental

Conditions:

CERCLA Funding in FY 94:

\section{Albuquerque Operations Office}

16,000 acres (25 square miles)

Placed on the NPL on May 31, 1994.

The facility was originally constructed in 1942 for the U.S. Army Ordnance Corps for loading conventional ammunition shells and bombs. In 1951, the Atomic Energy Commission (DOE's predecessor) took over the main plant and surrounding 10,000 acres for use as a nuclear weapons production facility. The Pantex Plant's current functions include the fabrication of chemical high explosives; high-explosives development work in support of the design laboratories; and nuclear weapons assembly, disassembly, testing, quality assurance, repair, retirement, and disposal.

Potential for soil and groundwater contamination from formulation and development of high explosives; machining and plating operations; weapon component tests (non-nuclear); facility and vehicle operations and maintenance activities; and historical waste management and disposal practices. High-explosive and solvent contamination may also have resulted from operations during World War II.

\section{Progress in Reaching Interagency Agreement}

Remediation of environmental conditions is currently being addressed under authority of a RCRA Part B Permit, issued June 6, 1991 by the Texas Natural Resources Conservation Commission (formerly the Texas Water Commission). FFA negotiations have been initiated with June 1995 scheduled as the completion date.

\section{Specific Cost Estimates and Budgetary Proposals Involved in Each Interagency Agreement}

Funds budgeted for environmental restoration at the Pantex Plant total \$24.1 million of appropriated funding for FY 95 and $\$ 9.1$ million for FY 96 according to the request in the President's Budget. These budget figures do not, however, reflect the rescission that occurred in FY 95. 


\section{Public Comments Regarding Interagency Agreements}

No formal public comment occurred in FY 94. Pantex Plant has continued its aggressive community relations program during FY 94 by hosting three public meetings, holding two administrative meetings with the Public Information Coordination Group, developing an Environmental Restoration and Waste Management community relations plan, holding quarterly Pantex management interface meetings, and developing a Pantex Plant Steering Committee. Supporting efforts include issuance of press releases for major milestones, dissemination of fact sheets and brochures, and maintenance of public reading rooms.

\section{Progress in Conducting Remedial Investigations/Feasibility Studies}

All 14 RFI Work Plans have been submitted to and approved by the Texas Natural Resource Conservation Commission. The assessment phase for nine projects is expected to be completed in FY 95

\section{Progress in Conducting Remedial Actions}

Fieldwork is ongoing at the Zone 12 Groundwater, Miscellaneous Chemical Spills, and Fire Training Area Burn Pit Units. The Pantex Environmental Restoration program has been rebaselined, resulting in significant cost and schedule savings over the previous baseline. Interim actions on the Fire Department Burn Pits, former Cooling Tower and several Underground Storage Tanks should be complete in FY 95. 
Office:

Size:

NPL Status:

Mission:

Overview of Environmental Conditions:
Grand Junction Projects Office

110 acres (0.02 square mile) (Mill Site), plus approximately 410 vicinity properties in the town of Monticello and 27 peripheral properties.

Facility comprised of two individual NPL sites: the Mill Site was placed on the NPL on November 21, 1989 and the Vicinity Properties on June 10, 1986.

Former uranium milling operation.

Soil, groundwater, and surface water contamination from radioactive mill tailings, process equipment, and milling operations. Approximately 2.6 million cubic yards of contaminated material.

CERCLA Funding in FY 94:

$\$ 15,851,000$

\section{Progress in Reaching Interagency Agreement}

DOE, EPA Region VIII, and the State of Utah negotiated and signed an FFA for the Monticello Mill Site and the Vicinity Properties. This FFA, which covered both NPL sites, was executed on December 22, 1988.

\section{Specific Cost Estimates and Budgetary Proposals Involved in the Federal Facility Agreement}

Funds budgeted for environmental restoration under the FFA at the Monticello Mill Site and Vicinity Properties total \$23.8 million of appropriated funding for FY 95 and $\$ 34.6$ million for FY 96 according to the request in the President's Budget. These budget figures do not, however, reflect the rescission that occurred in FY 95.

\section{Public Comments Regarding Federal Facility Agreement}

No new public comments regarding the FFA were received in FY 94. 


\section{Progress in Conducting Remedial Investigations/Feasibility Studies}

Mill Site: $\quad$ The RI/FS addressing mill tailings and 22 peripheral properties was completed in 1990. An additional RU/FS addressing groundwater and surface water contamination and contamination of five peripheral properties commenced in 1992. A Phase I RI/FS work plan was approved by EPA and the State of Utah and field activities were initiated. The baseline surface water and groundwater sampling for the Mill Site (OU 3) RI was completed and a Baseline Data Summary Report prepared. The Draft Final Work Plan for OU 3 RI/FS work was submitted in July 1994.

Vicinity

Properties: The RI/FS for the Vicinity Properties was completed in calendar year 1989.

\section{Progress in Conducting Remedial Actions}

Mill Site: $\quad$ The ROD for OUs 1 and 2 of the Mill Site was signed by EPA in August 1990 and by DOE in September 1990; construction of site preparation facilities at OU 1 has commenced. These facilities include the installation of surface water drainage control structures, including the runoff retention pond for the 78-acre site and contiguous peripheral properties. Construction of the staging area, including decontamination facilities, and the runoff retention pond was completed. During FY 94 at OU 2, remedial action was started at four peripheral properties and was completed at three properties.

Vicinity

Properties:

The ROD covering the Vicinity Properties was signed by EPA in September 1989 and by DOE in December 1989; since the last Annual Report to Congress, remedial actions have been completed on 305 of the project total of 410 . Sixty-two Vicinity Properties were remediated in FY 94. 
Office:

Size:

NPL Status:

Mission:

Overview of

Environmental

Conditions:

in FY 94:

\section{Richland Operations Office}

359,680 acres (562 square miles)

Four areas were placed on the NPL on October 4, 1989 (Areas 100, 200, 300, and 1100).

Chosen in 1943 for the Manhattan Project, the Hanford Site was used to produce plutonium for the world's first nuclear weapons. Today the focus of activities is site cleanup and environmental restoration; scientific and environmental research; development and application of radioactive waste and hazardous waste management technology; and design, construction, and operation of major energy-related test and development facilities.

Onsite soil, groundwater, and sediment contamination by various hazardous and radioactive substances. Various levels of radionuclides are also routinely identified in the Columbia River.

\section{Progress in Reaching Interagency Agreements}

DOE, EPA Region X, and the State of Washington negotiated and signed the Hanford Federal Facility Agreement/Consert Order (hereafter referred to as the Tri-Party Agreement) on May 15, 1989. This Tri-Party Agreement provides the framework for effective investigation of waste sites and subsequent remediation of hazardous and mixed waste contamination at Hanford. An annual update is prepared to address additional problems and to incorporate schedules agreed to in approved RI/FS work plans or other work scopes agreed to by the three parties. Revision 2 of the Tri-Party Agreement was published in September 1992, which included the second and third amendments to the Consent Order.

On May 23, 1993 negotiations began on significant changes to the Tri-Party Agreement. Change for CERCLA activities included development and inclusion of milestones related to the proposed Environmental Restoration Disposal Facility, consolidation of the 300 Area OUs into a single CERCLA project, and accelerated groundwater remediation projects. The proposed Environmental Restoration Disposal Facility has incorporated NEPA values through the CERCLA process. The amended Tri-Party Agreement was signed on January 25, 1994. For detailed information regarding the Tri-Party Agreement, see the FY 91 CERCLA 120 report to Congress. 
In July 1994, the DOE, EPA Region X, and the Washington State Department of Ecology agreed to negotiate on matters related to Hanford's "Refocusing Environmental Restoration" program. The parties agreed to negotiate cleanup schedules in order to achieve earlier remediation of sites along the Columbia River, and to increase emphasis on protecting and remediating groundwater. In addition, the parties agreed to consult with affected Indian Nations and other stakeholders to seek and respond to their values and concerns. The parties concluded formal negotiations on September 30, 1994. The public comment period for stakeholder participation is expected to begin in December 1994 and conclude in mid-January 1995.

\section{Specific Cost Estimates and Budgetary Proposals Involved in Each Interagency Agreement}

Funds budgeted for environmental restoration under the Tri-Party Agreement total $\$ 163.3$ million of appropriated funding for FY 95 and $\$ 119.0$ million for FY 96 according to the request in the President's Budget. These budget figures do not, however, reflect the rescission that occurred in FY 95.

\section{Public Comments Regarding Interagency Agreements}

Amendments and updates to the Tri-Party Agreement are subject to public comment periods prior to signature by the three parties. The Tri-Party Agreement renegotiation package underwent public comment from October 3 to December 14, 1993. No issues were raised specifically pertaining to CERCLA activities. The amendment was signed by the three parties on January 25,1994 . For detailed information regarding the Tri-Party Agreement comment process, see the FY 91 CERCLA 120 report to Congress. All future changes to the Tri-Party Agreement will also be subject to public review and comment.

\section{Progress in Conducting the Remedial Investigations/Feasibility Studies}

The Hanford Site includes a broad range of waste units that contain either radioactive, hazardous, mixed (both radioactive and hazardous), or nonradioactive/nonhazardous solid waste. Certain hazardous substances and hazardous wastes remain on and under the Hanford Site and have been detected in groundwater and surface water. An estimated 5 billion cubic yards of solid and dilute liquid waste, including hazardous substances, mixed waste, and hazardous waste and constituents, have been disposed of at the Hanford Site.

All remediation work at the Hanford Site is included within four NPL sites (the 100,200, 300, and 1100 Areas) and 74 source OUs containing 1,249 identified hazardous waste sites ( 985 past-practice sites), and groundwater OUs. OUs were prioritized by EPA and the State of Washington in 1989 for investigation based on an initial assessment of environmental risk potential.

In September 1994, the DOE Richland Operations Office completed cleanup of the North Slope and the Arid Lands Ecology (ALE) Reserve. This work represents a major accomplishment for the Environmental Restoration program at the Hanford Site. Reports documenting the cleanup have been given to the regulators. After the regulators approve the reports, approximately 46 percent of the site will be available for other uses. The DOE Richland Operations Office is planning public outreach programs for FY 95 to receive public opinion on the future management of the ALE Reserve.

The following activities were accomplished during FY 94:

- Construction of the Hanford Prototype Barrier (for long-term isolation of contaminated soils) was completed at the 200-BP-1 OU. 
- Three Work Plans were submitted.

- Four pump-and-treat treatability tests at 200-BP-5 (two tests), 200-UP-1, and 200-ZP-1 were initiated.

- Three CERCLA Proposed Plans to the regulators for the 100-DR-1, 100-HR-1, and 100-HR-3 OUs were submitted.

- The 100-BC-1 OU soil washing and 100-HR-1 excavation OU treatability tests were completed.

- The burial ground excavation treatability test at 118-B-1 was initiated.

- A total 113,000 gallons of groundwater contaminated with chromium VI at the 100-HR-3 OUs were treated.

- $\quad$ Removal of carbon tetrachloride at the 200-ZP-2 OU (using a vapor extraction system) was continued. A total of 92,387 pounds of carbon tetrachloride have been extracted as of FY 94 .

- The Environmental Restoration Disposal Facility CERCLA Regulatory Package was submitted to the regulators.

- Three Focused FS Reports were submitted.

- One Phase 3 FS Report were submitted.

- $\quad$ One Phase 2 RI Report was submitted.

- Six limited Field Investigation Reports were submitted.

\section{Progress in Conducting Remedial Actions}

The most significant accomplishment made in FY 94 was the completion of cleanup at the North Slope and the ALE Reserve. These areas account for approximately 46 percent of the Hanford Site, and are located on the northern and southern sides of the Columbia River. Reports documenting the cleanup have been given to regulators for their review and approval. Once the regulators approve the reports, these areas can be made available for other uses.

Under the Hanford Site Past Practice Strategy, sites that pose a threat to human health and the environment are identified. These sites are considered for Expedited Response Actions (ERAs).

In March 1993, an Agreement in Principle was signed committing DOE to cleanup of the North Slope and the ALE Reserve by October 1994. These areas have no radionuclide contamination and represent approximately 46 percent of the Hanford Reservation. DOE met this commitment and has now made the land available for other uses.

- The ALE Reserve ERA covers 120 square miles along the southwestern border of the Hanford Site and encompasses Rattlesnake Mountain and the 1100-IU-1 OU. The area was set aside as a natural research area in 1967. This area contains a Nike Missile Launch Site and Control Center. 
The North Slope ERA covers about 134 square miles on the northern and eastern borders of the Hanford Site, north of the Columbia River. The area contained antiaircraft guns, Nike missile emplacements, and landfills. It also contains a small landfill used by the U.S. Bureau of Reclamation to dispose of soil and storage tanks contaminated with the herbicide 2,4-D. Some 80 to 90 percent of the physical hazards have been removed, and ordnance archive research has been completed.

The following ERA activities also were accomplished in FY 94:

- The 200 West Area carbon tetrachloride treatment site (located in the 200-ZP-2 OU) vapor extraction continues. The system is now automated. Through September 1994, more than 92,000 pounds of carbon tetrachloride have been removed.

- The N-Springs ERA is located near the N-Reactor. Past liquid effluent discharges have led to strontium-90 radionuclide releases along the southern bank of the Columbia River, known as N-Springs. An Engineering Evaluation/Cost Analysis has been performed and the EPA has issued an Action Memorandum authorizing the start of work.

\section{Enforcement Activities}

In October 1990, DOE stopped construction of the low-level mixed waste analytical laboratory (Milestone M-14-00) in order to review options for obtaining analytical services from commercial laboratories. DOE subsequently resumed construction of a smaller laboratory. In October 1991, DOE submitted a request to change Milestone M-14-00 from construction of a laboratory to assurance of adequate laboratory capacity for mixed waste samples under the IAG. This request was denied by EPA and the State of Washington in November 1991, and DOE initiated dispute resolution under the IAG. In April 1992, the Senior Executive Committee agreed on a proposal to resolve the issue. As a result of the delay in schedule, and based on public comment, the state required further changes to the agreement to mandate that analytical laboratory services be acquired in the vicinity of Hanford. In addition, the state required DOE to pay a $\$ 100,000$ penalty, to perform an ERA of the N-Springs, and to establish IAG milestones for completion. DOE is committed to seek funding in FY 94 and beyond to complete existing (approved) ERAs and the N-Springs response action.

DOE has completed an Engineering Evaluation/Cost Analysis for the N-Springs ERA. DOE has also received an Action Memorandum from the Washington State Department of Ecology directing them to proceed with the selected alternative of barrier wall construction and emplacement of a groundwater pump and treat operation. Proposals for design and construction services for the barrier wall were received on September 27, 1994, and a contract award is expected to be issued in early FY 95. 
Office:

Size:

NPL Status:

Mission:

\section{Environmental \\ Conditions:}

Overview of
Bonneville Power Administration (BPA)

250 acres $(0.4$ square mile)

Placed on the NPL on November 21, 1989.

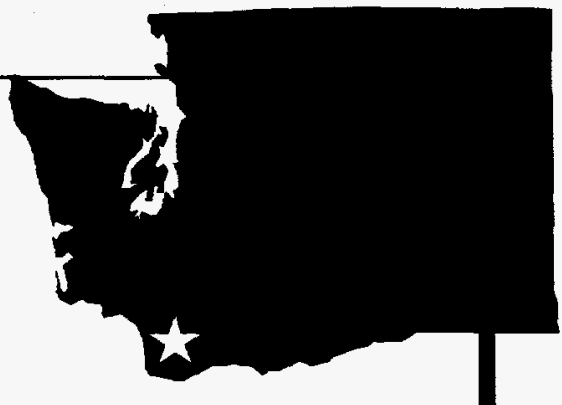

The Ross Complex, in operation since the late 1930s, acts as BPA's central control center for the transmission of electricity throughout the Pacific Northwest. The complex also acts as a research and testing, maintenance, construction, operations and waste handling facility for BPA.

Soil contamination due to historical disposal of PCB-laden capacitors; potential solvent contamination of groundwater.

CERCLA Funding in FY 94:

$$
\$ 1,500,000
$$

\section{Progress in Reaching Interagency Agreement}

DOE, EPA Region X, and the State of Washington executed an IAG for the Ross Complex site on May 1, 1990. The agreement serves as a framework for conducting remedial activities in accordance with CERCLA Section 120 and the National Contingency Plan.

\section{Specific Cost Estimates and Budgetary Proposals Involved in Each Interagency Agreement}

Funds budgeted for environmental restoration under the IAG total $\$ 1.0$ million for FY 95 and $\$ 0$ million for FY 96.

\section{Public Comments Regarding Interagency Agreements}

No new public comments regarding the IAG were received in FY 94.

\section{Progress in Conducting Remedial Investigations/Feasibility Studies}

The RI/FS scope of work was completed and submitted to EPA Region X and the State of Washington on March 15, 1990. The RI/FS work plan was submitted to all parties on June 7, 1991. It was reviewed and approved by EPA and the state. Phase I of the RI field work was completed in September 1991. Field work for Phase II of the RI was completed in August 1992. 
In an agreement with EPA and the state, the site was divided into two OUs. OU A addresses surface soil contamination, and OU B addresses below-surface contamination, principally groundwater.

No further actions were required in FY 94.

\section{Progress in Conducting Remedial Actions}

The RI report for OU A suggested that contaminant concentrations found in the soils at the Ross Substation, Capacitor Test Lab and Wood Pole Storage Area, East may pose an unacceptable risk of occupational exposure to carcinogens. Remediation of Ross Substation and the Capacitor Test Lab was accomplished by removing PCB-contaminated surface soil in January 1994. Onsite remediation of the Wood Pole Storage Area was initiated during the summer of 1994.

In addition, the results of the $\mathrm{RI}$ for $\mathrm{OU} \mathrm{A}$ indicated that certain contaminant concentrations in seven individual waste units exceeded soil cleanup levels promulgated under the Washington State Model Toxics Control Act. BPA undertook independent actions at these seven locations consisting of excavation and disposal of surface soils.

Based on the draft RI report for OU B, it has been demonstrated that the residual occurrence of limited volatile organics in the groundwater does not constitute an onsite or offsite risk to human health. Continued groundwater monitoring is planned for the next 2 to 5 years. The last groundwater analysis conducted in September 1994 showed that for all monitoring wells tested contaminants of concern were below maximum contaminant levels.

Cleanup of the Capacitor Test Lab, initiated in January 1994, is now complete. Installation of a multilayer cap over the Fog Chamber Dump began in FY 94 and is expected to be complete in FY 95. Contaminated soil from the Wood Pole Storage Area was excavated in the summer of 1994 and is now being treated onsite utilizing enhanced bioremediation. Removal of PCB-contaminated soil from the Ross Substation was accomplished in January 1994, leaving only the capacitor yard cleanup for the summer of 1995 when PCB equipment is scheduled for replacement. This PCB removal is the last of the remediation activities included in the RODs. 


\section{SECTION IV}

SITE SUMMARIES FOR SELECTED FACILITIES NOT ON THE NPL (BY STATE) 
This section of the annual report to Congress provides descriptions of selected U.S. Department of Energy (DOE) facilities not on the National Priorities List (NPL). This section is not required by Comprehensive Environmental Response, Compensation, and Liability Act (CERCLA) 120(e)(5); it is provided for public information. The information provided includes background summary information, environmental conditions, and funding information. Figure II-2 presents the geographic location of the 13 non-NPL sites highlighted in this section. 
This Page Intentionally Left Blank.

IV-2 


\section{LAWRENCE BERKELEY LABORATORY}

\section{Berkeley, California}

Office:

Size:

Mission:

Overview of

Environmental

Conditions:

\section{CERCLA Funding} in FY 94:

\section{Oakland Operations Office}

130 acres $(0.2$ square mile)

The Lawrence Berkeley Laboratory (LBL) was moved in 1940 to its present location from elsewhere on the University of California at Berkeley campus. LBL is engaged primarily in basic energy research such as high-energy physics, nuclear physics, heavy-ion fusion, magnetic fusion energy, biology, and medicine.

Onsite releases of heavy metals and other pollutants to the sanitary sewer system and soil and groundwater contamination by chlorinated hydrocarbons, solvents, tritium, and motor fuels.

Remediation of environmental conditions at LBL is being addressed under authority of a Resource Conservation and Recovery Act (RCRA) permit, which includes corrective action requirements. The site has been classified as Site Evaluation Accomplished.

\section{Specific Cost Estimates and Budgetary Proposals}

Funds budgeted for environmental restoration at LBL total $\$ 3.9$ million of appropriated funging for Fiscal Year (FY) 95 and $\$ 4.2$ million for FY 96 according to the request in the President's Budget. These budget figures do not, however, reflect the rescission that occurred in FY 95.

\section{Progress in Conducting Remedial Actions}

LBL corrective actions are being conducted in compliance with the site's RCRA Part B Permit. As part of this process, a RCRA Facility Assessment (RFA) was conducted by the State of California and LBL. Because of the Part B Permit and the RFA requirement, the State of California requested LBL to submit an RCRA Facility Investigation (RFI) work plan in accordance with the RCRA corrective action process. The RCRA investigation process follows a phased approach starting with the RFA, followed by an RFI and corrective measures study. LBL completed its RFA in July 1992. RFI activity commenced in FY 92 and the RFI work plan was submitted to the State of California in November 1992. The first RFI progress report was sent to regulators in November 1994 and a second will be prepared by November 1995, with a final RFI report scheduled for delivery to regulators in February 1997. 
This Page Intentionally Left Blank.

IV-4 
Office:

Size:

Mission:

Environmental

Conditions:

CERCLA Funding in FY 94:
Albuquerque Operations Office

413 acres ( 0.6 square mile)

Established in 1956 to provide support services to the neighboring Lawrence Livermore National Laboratory, Sandia National Laboratories/California's initial mission was to provide ordnance engineering services to Lawrence Livermore National Laboratories. Current programs being carried out at Sandia National Laboratory/ California include nuclear weapons systems development and combustion, solar, and fusion research. The site was developed initially by the U.S. Navy in 1942 and later relinquished for DOE activities in 1956.

Potential soil and groundwater contamination from a diesel fuel leak and from historical land disposal practices.

$$
\$ 4,448,000
$$

Remediation of environmental conditions at Sandia National Laboratories/California is being addressed under authority of a State of California Cleanup Order.

\section{Specific Cost Estimates and Budgetary Proposals}

Funds budgeted for environmental restoration at Sandia National Laboratories/California total $\$ 4.2$ million of appropriated funding for FY 95 and \$2.7 million for FY 96 according to the request in the President's Budget. The budget figures do not, however, reflect the rescission that occurred in FY 95.

\section{Progress in Conducting Remedial Actions}

On October 15, 1987 a PA/SI was submitted to EPA in response to CERCLA Section 120 requirements. To date, EPA has not completed a Hazard Ranking System evaluation for this site.

In December 1989, the State of California Regional Water Quality Control Board (RWQCB) issued a Site Cleanup Order (No. 89-184) to DOE and the Sandia Corporation. This order modified Order 88-142 requiring the consolidation of all site work to be accomplished by the Sandia Corporation and DOE, and set forth provisions and specifications for development and implementation 
of soil cleanup alternatives for identified areas of soil and groundwater pollution. Four areas of potential soil and groundwater pollution were identified in the Cleanup Order. Trudell Auto Repair Shop, Fuel Oil Spill, Navy Landfill, and Miscellaneous Sites. RIs at all four sites were completed in 1991.

Regarding the cleanup of the Fuel Oil Spill site, authorization to proceed as recommended with an in-situ bioremediation pilot study was provided in December 1990. The remedial action plan for the Fuel Oil Spill was submitted to the State of California for review in March 1992. In October 1993, the State of California approved the startup of the bioremediation pilot study. An interim remedial measure is taking place to protect groundwater while the bioremediation pilot study is being constructed and implemented. Construction of the pilot project was initiated.

The Navy Landfill Solid Waste Water Quality Assessment Test report was submitted for review on June 29, 1990, as scheduled, recommending the "No Action Alternative." Groundwater monitoring will continue through 1994 to address RWQCB concerns.

The Miscellaneous Sites investigation found contaminants present in concentrations far below regulatory guidelines. The report was submitted to the State of California recommending "no further action." The RWQCB has agreed to closure of the assessment phase; no remedial activities will be necessary.

Remedial activities associated with the Trudell Auto Repair Shop were completed in September 1990 and the site was closed in December 1990. 
Office:

Size:

Mission:

Overview of

Environmental

Conditions:

CERCLA Funding in FY 94:

\section{Western Area Power Administration (WAPA)}

Approximately 21 acres ( 0.03 square mile)

500/230 kilovolt $(\mathrm{kV})$ electrical substation.

Some onsite subsoil oil and creosol contamination under the $230 \mathrm{kV}$ yard area. Very low potential for migration due to clays.

A portion of the Federal property at Tracy Pump and Substation is owned by DOE and another portion is owned by the U.S. Department of the Interior (DOI).

\section{Specific Cost Estimates and Budgetary Proposals}

Funds budgeted for environmental restoration at Tracy Pump and Substation total $\$ 0$ million of appropriated funding for FY 95 and \$0 million for FY 96 according to the request in the President's Budget. The budget figures do not, however, reflect the rescission that occurred in FY 95.

\section{Progress in Conducting Remedial Actions}

A Preliminary Assessment (PA) was submitted to both the U.S. Environmental Protection Agency (EPA) and the State of California in July 1990 for a portion of federally owned land at the Tracy location. The results of the PA identified an old landfill located on a portion of DOE's property. This finding in turn requires that a State of California-authorized Preliminary Environmental Assessment (PEA) be conducted on this portion of the federal property. The DOI took the lead in preparing the PEA with DOE as an interested party (since the State of California considers the site all under federal ownership). The PEA for the old landfill was submitted to the State of California in November 1992. The State of California has not yet responded to the PEA submitted.

A preliminary assessment/site investigation (PA/SI) for all DOE-owned property at the Tracy facility was completed in FY 93. In the first quarter of FY 94, WAPA received a letter from EPA Region IX indicating that no further action would be required for the studied area. WAPA anticipates that the Tracy facility will be given Site Evaluation Accomplished status in the next docket (Update \#9). 
This Page Intentionally Left Blank. 
Office:

Size:

Mission:

Overview of

Environmental

Conditions:

CLA Funding

in FY 94:
Albuquerque Operations Office

100 acres ( 0.2 square mile)

The plant's mission is small-volume production of selected hightechnology nuclear weapon components that require strict control of materials and processes in an ultraclean environment. These conditions were imposed by the plant's first assignment, the development of neutron generators, used as external initiators of nuclear weapons. The plant has been an essential part of the nation's Nuclear Weapons Complex, but is scheduled to stop production of weapons-related components in FY 95. The plant's product line has expanded to include lightning arrestor connectors, capacitors, magnetics, optoelectronic devices, and other similar components. Some of these product lines are now being investigated for conversion to commercial and nonmilitary applications.

Onsite groundwater contamination from the storage and disposal of drummed wastes and construction debris containing solvents and volatile organic compounds (VOC). Contamination on a 4.5-acre site adjacent to (formerly part of) the Pinellas plant is of concern because of offsite groundwater contamination.

\section{$\$ 1,030,000$}

Remediation of environmental conditions at the Pinellas Plant is being addressed under authority of a Federal RCRA permit that includes corrective action requirements and state cleanup or Superfund statutes. The site has been classified as Site Evaluation Accomplished.

\section{Specific Cost Estimates and Budgetary Proposals}

Funds budgeted for environmental restoration at the Pinellas Plant total $\$ 0.8$ million of appropriated funding for FY 95 and $\$ 2.1$ million for FY 96 according to the request in the President's Budget. The budget figures do not, however, reflect the rescission that occurred in FY 95. 


\section{Progress in Conducting Remedial Actions}

DOE submitted PA/SI information on the Pinellas Plant to EPA Region IV on October 15, 1987. Remedial activities at the Pinellas Plant are being conducted under a RCRA permit issued February 9, 1990.

RFI field work for the Miscellaneous Sites was completed in June 1991, and the RFI report was conditionally approved by EPA in FY 92; final approval was received in FY 93. Of the 15 original Solid Waste Management Units (SWMUs) in the Miscellaneous Sites identified during the RFA, four (the Former Pistol Range, the Old Drum Storage Site, the Industrial Drain Leaks, and the Northeast Site) were recommended for corrective action, while 11 (the West Pond, the Diesel Fuel Spill, the Southwest Ditch, the Current Fire Department Training Tank, the Building 500 Spill Site, the Spray Irrigation Site, the Metallic Anomaly, the Trench Site, the Closed Fire Department Training Site, the Incineration Site, and the Incineration Ditch) were recommended for no further action. Cleanup activities at the Pistol Range Site were conducted in the winter of 1993 under an interim action approved by EPA. The site was effectively remediated with no further action required. A new SWMU, the West Fenceline Area, was identified in 1993 and added to the permit. The Hazardous and Solid Waste Amendments permit is anticipated to be modified in 1995 to eliminate the 12 "no further action" sites.

The 4.5-Acre Site interim remedial action began in December 1988 with the development of a groundwater recovery system to draw the VOC plume back onto the site. An iron removal system was added to pretreat the groundwater and improve the efficiency of the VOC removal. This action has successfully stabilized the VOC plume and is in the process of repositioning it back onto the 4.5-Acre Site. The State of Florida has the lead for this action and is using CERCLA cleanup requirements. During FY 94, data collection for the Remedial Action Plan at the 4.5 Acre Site began in anticipation of a completed plan in 1995 .

Pumping of contaminated groundwater from four recovery wells at the Northeast Site to the 4.5-Acre Site treatment system has been underway since early 1992 under an interim corrective measure plan approved by EPA. Plans for final corrective measures for the Northeast Site are being developed, with implementation expected in late 1996. The Corrective Measure Study was submitted in FY 94.

A site assessment report for the West Fenceline Area was completed and approved in FY 93. An RFI was completed and approved in FY 94. Plans for interim measures for the West Fenceline Area were developed in 1994.

The RFA for the Production Component Scrap Area was submitted to EPA on December 28, 1993. Based on that assessment, EPA determined that no further action is needed.

A RCRA Facility Assessment Report for the Wastewater Neutralization Building 200 Area was completed and approved by EPA in FY 94. Further investigation involved the installation of 15 additional groundwater monitoring wells. Monitoring will be continued through FY 95.

Completion of the Corrective Measures Study Report, Industrial Drum Leaks - Building 100 Area and Old Drum Storage Site in 1994 will pave the way for design data acquisition to begin in early 1995 . Installation of the groundwater recovery system will utilize treatment system components of the Northeast Site. 


\section{HINTON HAZARDOUS WASTE STORAGE FACILITY}

Hinton, Iowa
STORAGE FACILITY
Office:
Western Area Power Administration
(WAPA)
Size:
0.5 acre
Mission:
Storage facility supporting electric power distribution.
Overview of
Environmental
Conditions:
Onsite soil contamination from spillage of pentachlorophenol, a wood preserving product, was remediated in November 1993 and the facility is currently undergoing closure.

\section{CERCLA Funding}
in FY 94:
$\$ 120,000$

Remediation of environmental conditions at the Hinton Hazardous Waste Storage Facility is being addressed under a 1987 RCRA agreement with EPA Region VII.

\section{Specific Cost Estimates and Budgetary Proposals}

Funds budgeted for environmental restoration at the Hinton Hazardous Waste Facility total \$0 million of appropriated funding for FY 95 and $\$ 0$ million for FY 96 according to the request in the President's Budget. The budget figures do not, however, reflect the rescission that occurred in FY 95.

\section{Progress in Conducting Remedial Actions}

WAPA prepared a sampling and analysis report in May 1990, which was forwarded to EPA. Based on the results of the sampling effort, WAPA removed soils contaminated with pentachlorophenol, a wood-preserving product used to treat wooden utility poles. This soil was stored onsite under a RCRA Interim Permit for storage until an EPA-approved disposal/destruction method was identified, and a cleanup report was sent to EPA Region VII in September 1991. These soils were incinerated in November 1993, and WAPA received certificates of disposal from the disposal facility on November 30, 1993. The Hinton RCRA storage facility currently is undergoing closure. EPA Region VII received the closure plans for review and approval on December 16, 1993. EPA Region VII is expected to accept the plan in the first quarter of FY 95; final closure of the facility is expected to occur during the second quarter of FY 95. 
This Page Intentionally Left Blank. 


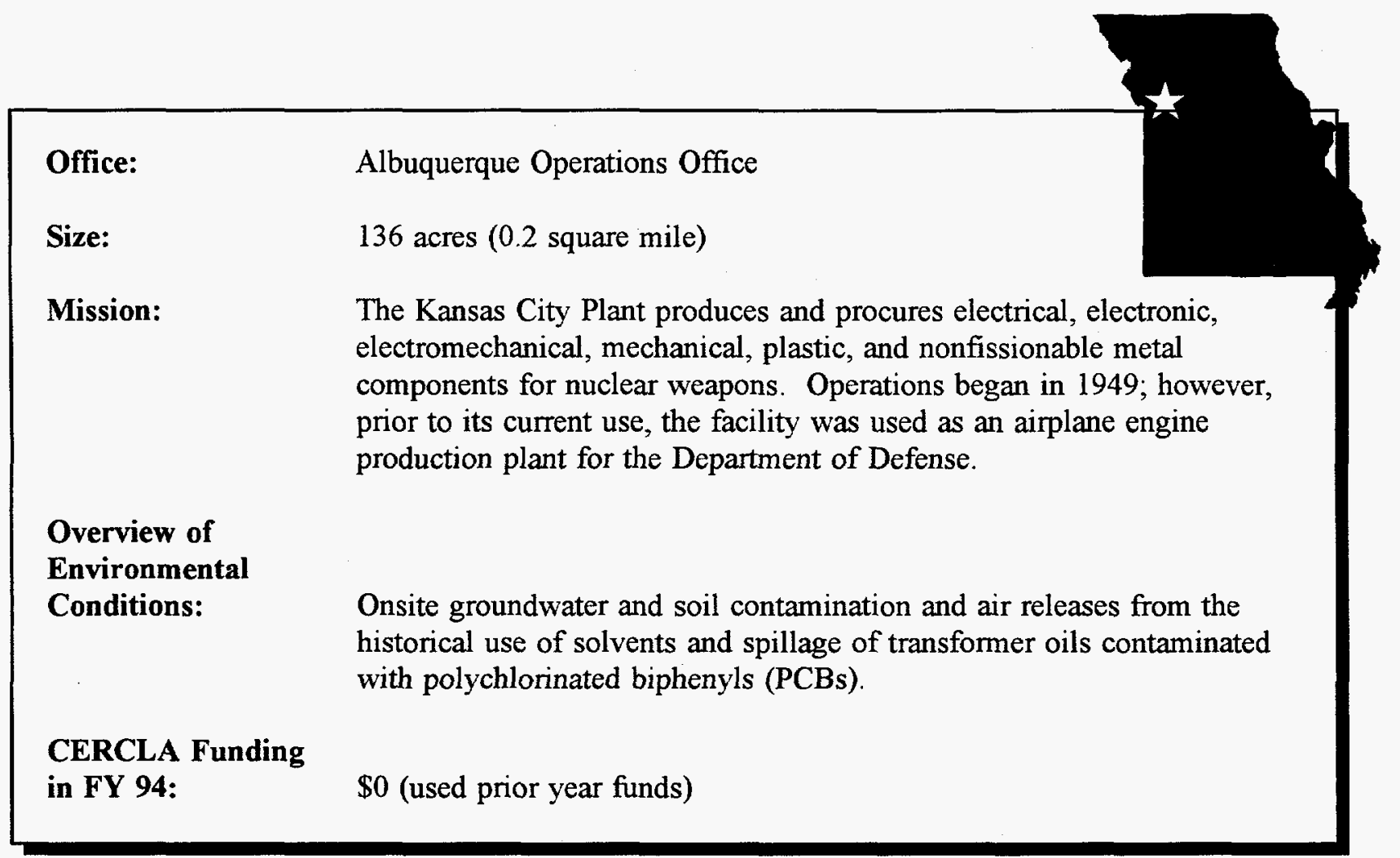

Remediation of environmental conditions at the Kansas City Plant is being addressed under a RCRA Section 3008(h) Administrative Order.

\section{Specific Cost Estimates and Budgetary Proposals}

Funds budgeted for environmental restoration at Kansas City Plant total $\$ 140,000$ of appropriated funding for FY 95 and $\$ 90,000$ for FY 96 according to the request in the President's Budget. The budget figures do not, however, reflect the rescission that occurred in FY 95.

\section{Progress in Conducting Remedial Actions}

Two Corrective Measures Studies have been submitted for EPA approval: the Miscellaneous Contaminated Sites, and the Outfall 001/Northeast Area. Five RFI reports have been approved by EPA: Department 26, Miscellaneous Contaminated Sites, Outfall 001/Northeast Area, Plating Building, and TCE Still Area. Three work plans have been approved by the EPA: two RFI work plans for Department 27 Inside and Maintenance Vehicle Repair Shop Sump, and one Interim Measure work plan for Miscellaneous PCB sites.

Field work for all 12 RFIs has been completed. 
Interim remediation was completed on Department 27 (outside), and corrective measure remediation was completed at the Abandoned Indian Creek Outfall. Groundwater interim measure treatment and monitoring continued using a newly installed water treatment system.

Kansas City Plant continued its community relations program by publishing six issues of Focus on the Environment and by welcoming public questions, concerns and comments. Two videotapes entitled Working Clean and Cleaning Up the Abandoned Indian Creek Outfall have been made available for community groups and schools. In addition, public library access to all deliverables made to EPA was maintained. 
Office:

Size:

Mission:

Overview of

Environmental

Conditions:
Nevada Operations Office

864,000 acres $(1,350$ square miles)

The Nevada Test Site, created in the early 1950 s, is used as a detonation and testing range for nuclear weapons.

Contamination of onsite groundwater and soil resulting from nuclear weapons testing activities.

CERCLA Funding in FY 94:

$\$ 38,887,000$

The environmental restoration activities at the Nevada Test Site are being conducted under DOE authorities. Negotiation of an FFA with the State of Nevada was initiated in FY 93 under RCRA and the Atomic Energy Act. Negotiations are expected to be completed during the third quarter of FY 95 . Preparation of a site-wide Environmental Impact Statement is underway.

\section{Specific Cost Estimates and Budgetary Proposals}

Funds budgeted for environmental restoration for Nevada Test Site total $\$ 25.8$ million of appropriated funding for FY 95 and $\$ 37.7$ million for FY 96 according to the request in the President's Budget. The budget figures do not, however, reflect the rescission that occurred in FY 95.

\section{Progress in Conducting Remedial Actions}

DOE submitted a PA and draft Hazard Ranking System scores for the Nevada Test Site and eight offsite locations to EPA Region IX on April 15, 1988. DOE has since rescored the Nevada Test Site, using the revised Hazard Ranking System. The Hazard Ranking System package was resubmitted to EPA Region IX in December 1991. The Nevada Test Site is being evaluated for potential listing on the NPL by EPA. Although EPA Region IX recommended that the site be listed, EPA has made no final decision.

Remediation activity undertaken thus far has centered on continued research into the development of a process to remediate large areas of soils contaminated with plutonium from past activities. Five bench-scale technologies have been tested. A preliminary risk assessment and a draft cost benefit analysis for these contaminated soil sites were completed. Technology development of radiation detection systems for plutonium also continued. In addition, an effort to identify, verify, and document all potential release sites, known as the Environmental Restoration Sites Inventory, was initiated. Progress on the Underground Test Area Operable Unit also continued. 
The Nevada Test Site continues remediation of inactive USTs.

There were several RCRA closure activities initiated during FY 94. The Area 27 Explosive Ordnance Disposal Area (a RCRA site) was closed. In addition, closure began for the $\mathrm{U}_{3} \mathrm{Fi}$ Injection Well, and characterization of three other RCRA sites is underway.

Work performed during 1993 for the Groundwater Characterization Project, renamed the Underground Test Area RI/FS Project, includes drilling of several new and reconfigured wells, development of a subproject work plan, and data analysis and modeling studies. A regional groundwater model and risk assessment are scheduled for completion in late 1995. 


\section{LOS ALAMOS NATIONAL LABORATORY}

Office:

Size:

Mission:

Overview of

Environmental

Conditions:
Albuquerque Operations Office

27,520 acres (43 square miles)

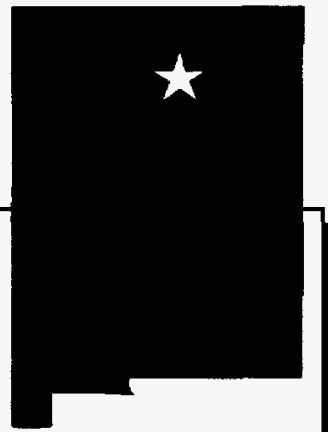

The Los Alamos National Laboratory (LANL) was originally established in 1943 by the U.S. Army's Manhattan Engineer District for the purpose of developing the first atomic bombs. The primary mission is nuclear weapons research and development. In addition, many programs are conducted at LANL in the nuclear, environmental, and energy sciences; fusion, laser isotope separation, and basic research in the area of physics; chemistry; radiology; and medicine.

Onsite soil contamination with various chemical and radiological contaminants resulting from historic waste management and disposal practices. Decommissioning of surplus contaminated structures.

CERCLA Funding in FY 94:

$\$ 76,456,000$

Remediation of environmental conditions at LANL is being addressed under authority of a RCRA permit, which includes corrective action requirements.

\section{Specific Cost Estimates and Budgetary Proposals}

Funds budgeted for environmental restoration at LANL total $\$ 68.7$ million of appropriated funding for FY 95 and $\$ 57.6$ million for FY 96 according to the request in the President's Budget. The budget figures do not, however, reflect the rescission that occurred in FY 95.

\section{Progress in Conducting Remedial Actions}

LANL submitted its PA/SI to EPA on October 15, 1987. When the site was scored using the Hazard Ranking System, LANL did not qualify for inclusion on the NPL.

During calendar year 1993, RFI work was in progress. In addition, some field work associated with RCRA closure requirements has been completed, and several interim remedial measures have been planned to facilitate ongoing construction projects. Decommissioning of TA-21 Buildings 3 and 4 South were begun in 1993. 
This Page Intentionally Left Blank. 


\section{SANDIA NATIONAL \\ LABORATORIES/ \\ NEW MEXICO}

Albuquerque, New Mexico

Office:

Size:

Mission:

Overview of

Environmental

Conditions:

CRCLA Funding

in FY 94:
Albuquerque Operations Office

15,600 acres (approximately 24.4 square miles)
Created by the Sandia Corporation in 1949, the primary function of the Sandia National Laboratories/New Mexico is the research and development of weapons which use nuclear explosives. This includes the design of the arming, fusing, and firing systems used in nuclear bombs and warheads. Other projects include nuclear reactor safety studies; development of safe transport and storage systems for special nuclear material including plutonium and uranium; radioactive waste disposal techniques and site studies; pulsed power research; vertical axis wind turbine research; and fossil fuel and geothermal energy research.

Onsite soil and groundwater contaminated with various chemical and radiological contaminants resulting from historical waste management and disposal practices.

Remediation of environmental conditions at Sandia National Laboratories/New Mexico has been initiated as a result of a RCRA permit issued by EPA which includes corrective action requirements.

\section{Specific Cost Estimates and Budgetary Proposals}

Funds budgeted for environmental restoration at Sandia National Laboratories/New Mexico total \$0.6 million of appropriated funding for FY 95 and \$0 million for FY 96 according to the request in the President's Budget. The budget figures do not, however, reflect the rescission that occurred in FY 95.

\section{Progress in Conducting Remedial Actions}

RFI activities at Sandia National Laboratories/New Mexico were initiated as a result of corrective action requirements in a RCRA permit issued by EPA. A number of sites are being addressed for cleanup, some sites are being cleaned up under RCRA through an agreement with EPA, while the remaining sites are being cleaned up under CERCLA. 
In an effort to characterize the hydrogeologic framework within which groundwater contamination may exist, the Site-wide Hydrogeologic Characterization Project Annual Report for Sandia National Laboratories/New Mexico was completed during FY 94. Sandia National Laboratories/New Mexico also completed seven RFI work plans that describe proposed characterization activities for 70 SWMUs and received final approval of the Chemical Waste Landfill Closure Plan by the New Mexico Environment Department. 
Office:

Size:

Mission:

Overview of

Environmental

Conditions:

CERCLA Funding

in FY 94:
Oak Ridge Operations Office

38,000 acres ( 48 square miles)

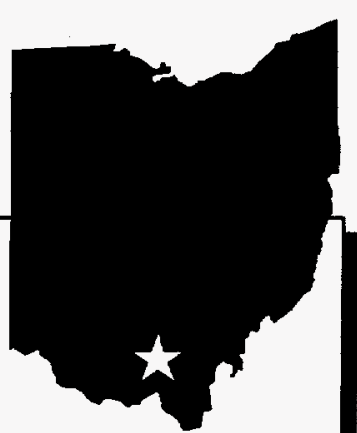

The Portsmouth Uranium Enrichment Complex has been in operation since 1954, enriching uranium-235 for national defense and commercial reactors. In July 1993, DOE officially transferred responsibility for site operations to U.S. Enrichment Corporation in accordance with the Energy Policy Act of 1992.

Onsite soil and groundwater contamination in several areas within the site from releases of chlorinated organics, radionuclides, heavy metals, and PCBs. The site has been divided into four quadrants containing a total of 103 SWMUs.

Remediation of environmental conditions at the Portsmouth Uranium Enrichment Complex is being addressed by a 1989 Administrative Order by Consent with EPA Region V under authority of Sections 3008(h) of RCRA and 106(a) of CERCLA, and a 1989 Consent Decree with the State of Ohio under Section 3008(h) of RCRA. An Ohio Agreement in Principle was signed in FY 94 to cover the costs of state oversight activities.

\section{Specific Cost Estimates and Budgetary Proposals}

Funds budgeted for environmental restoration under CERCLA at Portsmouth Uranium Enrichment Complex total $\$ 0$ million of appropriated funding for FY 95 and $\$ 0$ million for FY 96 according to the request in the President's Budget. The budget figures do not, however, reflect the rescission that occurred in FY 95.

\section{Progress in Conducting Remedial Actions}

On August 29, 1989, the State of Ohio and DOE finalized a Consent Decree under RCRA Section 3008(h), filed with the U.S. District Court of Ohio, Eastern Division. On September 27, 1989, DOE executed an Administrative Order by Consent under authority of CERCLA Section 106(a) and RCRA Section 3008(h) with EPA Region V. 
The Consent Decree is based on RCRA requirements, whereas the Administrative Order by Consent is based on both RCRA and CERCLA requirements. The Consent Decree and the Administrative Order by Consent were negotiated to be consistent so that all work will satisfy both the RCRA and CERCLA requirements. The CERCLA portion of the Administrative Order by Consent becomes effective only when radionuclide releases occur at the Portsmouth Uranium Enrichment Complex.

During FY 94, Portsmouth was not involved in any CERCLA activities. 


\section{COVINGTON SUBSTATION}

\section{Kent, Washington}

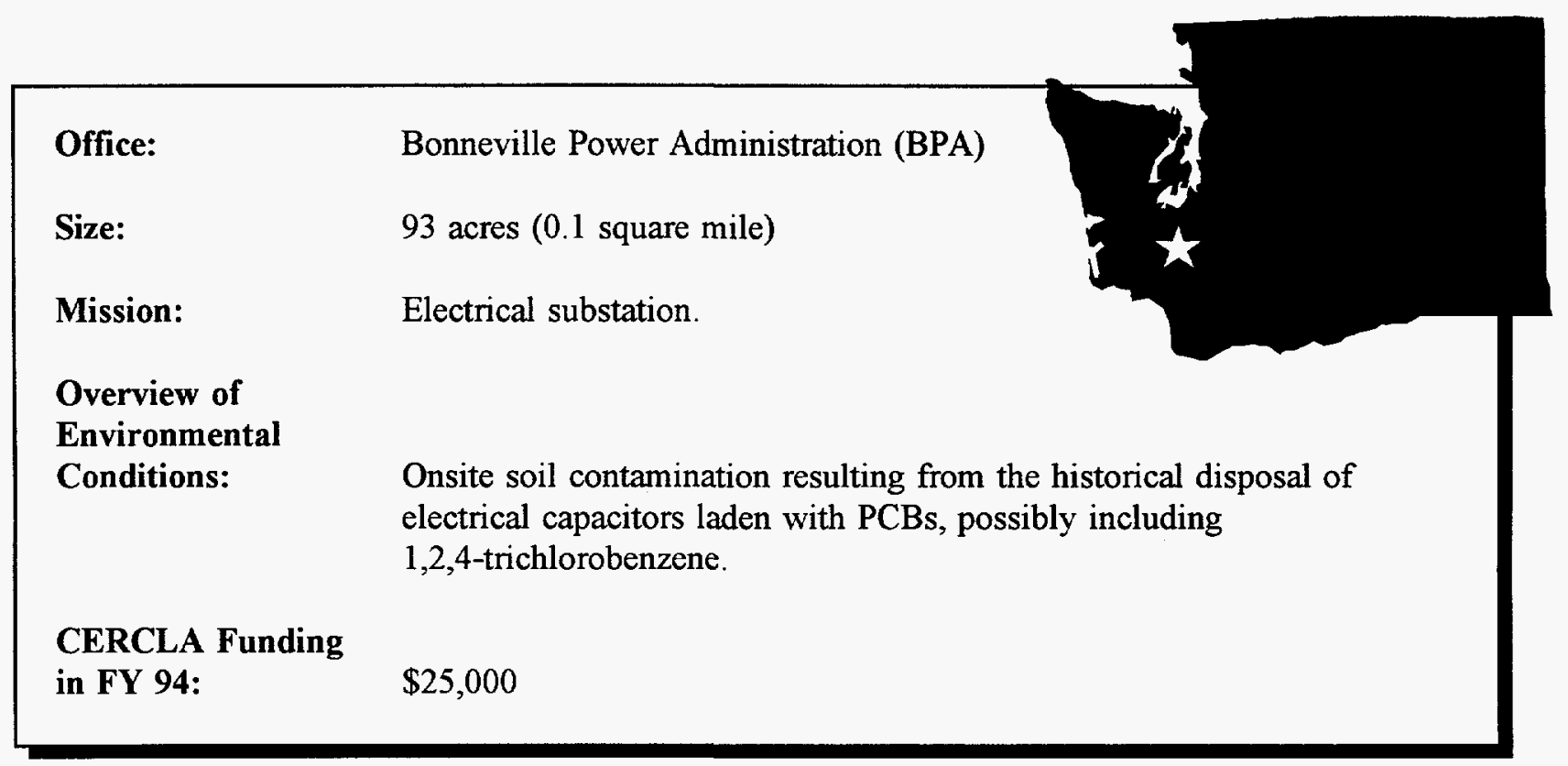

Covington Substation currently is undergoing the assessment and evaluation stage required by Section 120(d) of CERCLA.

\section{Specific Cost Estimates and Budgetary Proposals}

Funds budgeted for environmental restoration at Covington Substation, total $\$ 25,000$ for FY 95 and $\$ 25,000$ for FY 96.

\section{Progress in Conducting Remedial Actions}

A PA was completed and submitted to EPA Region X on May 16, 1990. The PA recommended that the Covington Substation not be considered for any further remedial action under CERCLA and proposed that a cleanup of the PCB disposal areas be conducted. Following consultation with EPA Region $\mathrm{X}$ and the State of Washington, interim cleanup activities were initiated during August 1991 and completed in September 1991. The final cleanup report was completed and sent to EPA Region X and the Washington Department of Ecology on February 21, 1992.

On December 7, 1992 EPA requested BPA to perform an SI at Covington Substation. The SI was submitted to EPA Region X on December 27, 1993; the site is awaiting site Hazard Ranking System scoring from EPA Region $\mathrm{X}$. 
This Page Intentionally Left Blank. 


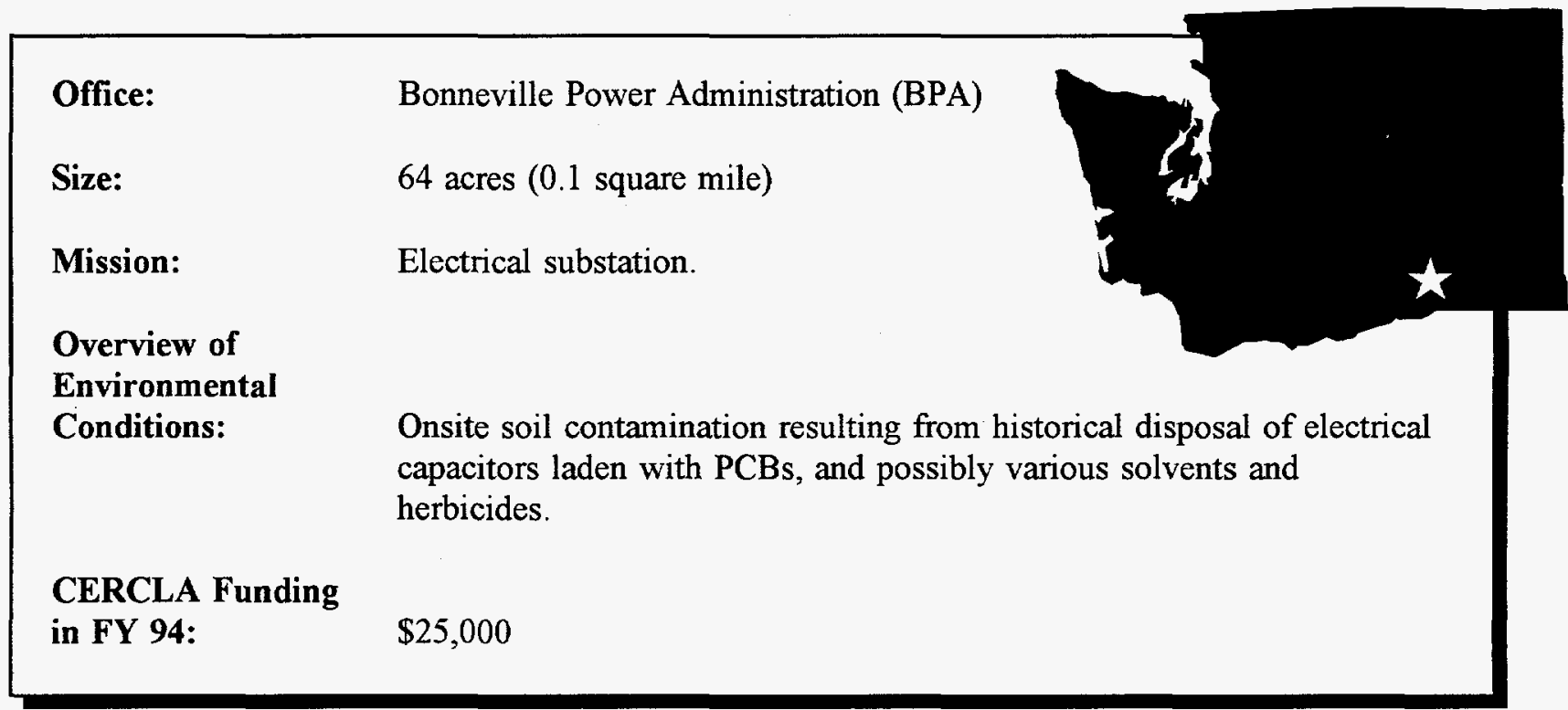

Midway Substation has completed a site investigation under the Washington State Model Toxics Control Act. A majority of the scheduled remediation was completed in calendar year 1992.

\section{Specific Cost Estimates and Budgetary Proposals}

Funds budgeted for environmental restoration at Midway Substation total $\$ 5,000$ for FY 95 and $\$ 5,000$ for FY 96.

\section{Progress in Conducting Remedial Actions}

A PA was completed and submitted to EPA Region X on March 27, 1990. In a May 15, 1990 letter, EPA Region X stated that, based on a Hazard Ranking System evaluation, a recommendation for no further action would be entered in the docket tracking system for the facility.

Discussions with the State of Washington led to the initiation of a site investigation in accordance with the Model Toxics Control Act. This investigative report was submitted to the Washington State Department of Ecology in November 1991. Soil cleanup commenced in March 1992 and was completed in May 1992. The soil cleanup report was submitted to the EPA and Department of Ecology in August 1992. Monitoring well installation was completed in September 1992. From September 1992 through December 1993, four sampling events were completed. No contamination has been detected. Sampling and analysis continues to show no detectable contaminants. 
This Page Intentionally Left Blank. 
Office:

Size:

Mission:

Environmental

Conditions:

\section{Morgantown Energy Technology Center}

80 acres ( 0.1 square mile)

This facility, which is not owned by DOE, was used to investigate process and environmental parameters of underground coal gasification technology.

Elevated levels of benzene and phenols in an onsite coal seam aquifer situated about 180 feet beneath the surface. The contaminants have migrated onto private property adjacent to the site.

CERCLA Funding in FY 94:

$\$ 1,865,000$

The requisite PA/SI for the Hoe Creek site was completed in the spring of 1993 and was submitted to EPA Region VIII for analysis and scoring under the Hazard Ranking System. As a result of the low Hazard Ranking System score, the Hoe Creek site was classified as Site Evaluation Accomplished and the site was not placed on the NPL. DOE was directed to work with the State of Wyoming to determine any site cleanup requirements

\section{Specific Cost Estimates and Budgetary Proposals}

Funds budgeted for environmental restoration at Hoe Creek total $\$ 2.0$ million of appropriated funding for FY 95 and $\$ 5.0$ million for FY 96 according to the request in the President's Budget. The budget figures do not, however, reflect the rescission that occurred in FY 95.

\section{Progress in Conducting Remedial Actions}

During FY 94, site characterization was completed through an Interagency Agreement with the Omaha District of the U.S. Army Corps of Engineers. Thirty-one wells were drilled at locations recommended by the state, and two quarterly rounds of samples of the groundwater were analyzed. The results were used to perform a cleanup alternatives study and risk assessment for the site, and the state is reviewing the cleanup alternatives report. The selected alternative will be incorporated as an appendix into the agreement with the state. An interim pump and treat action to inhibit continued migration of the contaminant plume off the site was completed during the summer and fall of FY 94. 
This Page Intentionally Left Blank. 
SECTION V

STATUS OF ALL DOE FACILITIES/SITES SUBJECT TO SECTION 120 OF CERCLA 


\section{STATUS OF ALL DOE FACILITIES/SITES SUBJECT TO SECTION 120 OF CERCLA}

This section of the Eighth Annual Report to Congress provides a comprehensive listing through Fiscal Year 1994 (FY 94) of all DOE facilities and sites subject to the reporting requirements of CERCLA Section 120. The list includes all facilities on the latest docket, plus sites where DOE is required to participate in or fund cleanups by Congressional Directive. The latest docket published at the time this Report to Congress was prepared was Docket Update \#8, dated November 10, 1993. 
This Page Intentionally Left Blank. 
Table V-1. Status of All DOE Facilities/Sites Listed on Docket Update \#8, Dated 11/10/93 ${ }^{1}$

\begin{tabular}{|c|c|c|c|}
\hline STATE & DOE FACILITY & $\begin{array}{l}\text { KNOWN OR SUSPECTED } \\
\text { PROBLEMS }\end{array}$ & CURRENT STATUS \\
\hline Arizona & Liberty Substation (WAPA) & $\begin{array}{l}\text { Onsite soil/chemical } \\
\text { contamination }\end{array}$ & $\begin{array}{l}\text { Not an NPL site. PA completed in FY 93; awaiting response } \\
\text { from EPA Region IX. }\end{array}$ \\
\hline \multirow[t]{8}{*}{ California } & $\begin{array}{l}\text { Laboratory for Energy-Health } \\
\text { Research (LEHR) }\end{array}$ & $\begin{array}{l}\text { Onsite soil and potential } \\
\text { offsite groundwater/chemical } \\
\text { and radioactive contamination }\end{array}$ & $\begin{array}{l}\text { Listed on Docket } 2 / 5 / 93 \text {; listed on NPL 5/31/94. RI/FS work } \\
\text { plan prepared and undergoing final review. }\end{array}$ \\
\hline & $\begin{array}{l}\text { Lawrence Berkeley } \\
\text { Laboratory }\end{array}$ & $\begin{array}{l}\text { Onsite soil and } \\
\text { groundwater/chemical } \\
\text { and radioactive contamination }\end{array}$ & Not an NPL site. RFI Progress Report submitted 11/94. \\
\hline & $\begin{array}{l}\text { Lawrence Livermore National } \\
\text { Laboratory - Main Site }\end{array}$ & $\begin{array}{l}\text { Onsite groundwater, } \\
\text { soil/chemical, and offsite } \\
\text { groundwater contamination }\end{array}$ & $\begin{array}{l}\text { NPL site. Draft and Final Remedial Design Report No. } 6 \\
\text { submitted; Final Remedial Design Report No. } 3 \text { issued; } \\
2 \text { groundwater treatment facilities constructed and placed in } \\
\text { operation. }\end{array}$ \\
\hline & $\begin{array}{l}\text { Lawrence Livermore National } \\
\text { Laboratory - Site } 300\end{array}$ & $\begin{array}{l}\text { Onsite groundwater, } \\
\text { soil/chemical, radioactive, and } \\
\text { offsite groundwater } \\
\text { contamination }\end{array}$ & $\begin{array}{l}\text { NPL site. Final SWRI report completed } 3 / 94 ; 2 \text { interim } \\
\text { groundwater facilities in operation; OU draft FS prepared; OU } \\
2 \text { draft and Final FS prepared and submitted; OU } 3 \text { draft FS } \\
\text { submitted. }\end{array}$ \\
\hline & $\begin{array}{l}\text { Naval Petroleum Reserve } \\
\text { Nos. } 1 \text { and } 2\end{array}$ & $\begin{array}{l}\text { Onsite soil/chemical } \\
\text { contamination }\end{array}$ & $\begin{array}{l}\text { Not an NPL site. Site characterized as No Further Remedial } \\
\text { Action planned. }\end{array}$ \\
\hline & Oxnard Facility & $\begin{array}{l}\text { Onsite suspected soil and } \\
\text { groundwater/chemical } \\
\text { contamination }\end{array}$ & $\begin{array}{l}\text { Not an NPL site. Phase II assessment currently being } \\
\text { conducted, final report to be issued 6/95. }\end{array}$ \\
\hline & Parker Dam Switchyard ${ }^{2}$ & $\begin{array}{l}\text { Onsite soil/chemical } \\
\text { contamination }\end{array}$ & $\begin{array}{l}\text { Not an NPL site. PA completed in FY 93; awaiting response } \\
\text { from EPA Region IX. }\end{array}$ \\
\hline & $\begin{array}{l}\text { Sandia National Laboratories/ } \\
\text { California }\end{array}$ & $\begin{array}{l}\text { Onsite soil and potential } \\
\text { groundwater/chemical } \\
\text { contamination }\end{array}$ & $\begin{array}{l}\text { Not an NPL site. Constructing/implementing in-situ } \\
\text { bioremediation pilot study at Fuel Oil Spill Site and approval } \\
\text { of bioremediation pilot study startup. Additional groundwater } \\
\text { monitoring at Navy Landfill. }\end{array}$ \\
\hline
\end{tabular}


Table V-1. Status of All DOE Facilities/Sites Listed on Docket Update \#8, Dated 11/10/93 (Continued)

\begin{tabular}{|c|c|c|c|}
\hline STATE & DOE FACILITY & $\begin{array}{l}\text { KNOWN OR SUSPECTED } \\
\text { PROBLEMS }\end{array}$ & CURRENT STATUS \\
\hline \multirow[t]{3}{*}{$\begin{array}{l}\text { California } \\
\text { (Continued) }\end{array}$} & $\begin{array}{l}\text { Santa Susana Field } \\
\text { Laboratories (Energy } \\
\text { Technology Engineering } \\
\text { Center) }\end{array}$ & $\begin{array}{l}\text { Onsite groundwater and } \\
\text { soil/chemical and radioactive } \\
\text { contamination; offsite } \\
\text { groundwater/chemical and } \\
\text { radioactive contamination }\end{array}$ & $\begin{array}{l}\text { Not an NPL site. Groundwater investigations continuing under } \\
\text { RCRA and RWQCB authorities. Site-wide RFI in progress. }\end{array}$ \\
\hline & $\begin{array}{l}\text { Stanford Linear Accelerator } \\
\text { Center }\end{array}$ & $\begin{array}{l}\text { Onsite groundwater and } \\
\text { soil/chemical contamination; } \\
\text { offsite soil/PCB contamination }\end{array}$ & Not an NPL site. Classified as Site Evaluation Accomplished. \\
\hline & $\begin{array}{l}\text { Tracy Pump and Substation } \\
\text { (WAPA) }\end{array}$ & $\begin{array}{l}\text { Onsite soil/chemical } \\
\text { contamination }\end{array}$ & $\begin{array}{l}\text { Not an NPL site. PA/SI submitted in FY 93. Region IX } \\
\text { indicated in early FY } 94 \text { that no further action would be } \\
\text { required on the site; Site Evaluation Accomplished status } \\
\text { expected in next Docket (Update \#9). }\end{array}$ \\
\hline \multirow[t]{5}{*}{ Colorado } & $\begin{array}{l}\text { Anvil Points Facility, Naval } \\
\text { Oil Shale Reserve No. } 3\end{array}$ & Onsite soil contamination & $\begin{array}{l}\text { Not an NPL site. Prior to FY 93, PA submitted and SI plan } \\
\text { requested by state. PA/SI document approved by EPA } 6 / 94 \text {; } \\
\text { cleanup not required; continued sampling. }\end{array}$ \\
\hline & $\begin{array}{l}\text { Grand Junction Projects } \\
\text { Office Remedial Action } \\
\text { Project }\end{array}$ & $\begin{array}{l}\text { Onsite soil and } \\
\text { groundwater/mixed waste } \\
\text { contamination }\end{array}$ & Not an NPL site. Classified as Site Evaluation Accomplished. \\
\hline & $\begin{array}{l}\text { Montrose Power Operations } \\
\text { Center (WAPA) }\end{array}$ & $\begin{array}{l}\text { Onsite soil/chemical } \\
\text { contamination }\end{array}$ & Not an NPL site. Classified as Site Evaluation Accomplished. \\
\hline & $\begin{array}{l}\text { National Renewable Energy } \\
\text { Laboratory }\end{array}$ & None known & Not an NPL site. Classified as Site Evaluation Accomplished. \\
\hline & $\begin{array}{l}\text { Rocky Flats Environmental } \\
\text { Technology Site (formerly } \\
\text { the Rocky Flats Plant) }\end{array}$ & $\begin{array}{l}\text { Onsite groundwater, surface } \\
\text { water, and soil/chemical, } \\
\text { radioactive, mixed } \\
\text { contamination; offsite } \\
\text { soil/radioactive contamination }\end{array}$ & $\begin{array}{l}\text { NPL site. 1 ROD completed and approved by regulatory } \\
\text { agencies; RI work plans for all } 15 \text { OUs approved by } \\
\text { regulatory agencies; RI field work complete at } 8 \text { OUs and } \\
\text { under way at } 7 \text { others; } 1 \text { Final and } 2 \text { draft RI reports submitted } \\
\text { to regulatory agencies; FSs for } 4 \text { OUs initiated; FS report } \\
\text { submitted; and } 1 \text { Phase II RFI/RI Work Plan completed and } \\
\text { approved. }\end{array}$ \\
\hline Connecticut & $\begin{array}{l}\text { Knolls Atomic Power } \\
\text { Laboratory, Windsor Site }\end{array}$ & None known & $\begin{array}{l}\text { Not an NPL site. Classified as Site Evaluation Accomplished } \\
\text { prior to FY 93; no further EPA action required. }\end{array}$ \\
\hline
\end{tabular}


Table V-1. Status of All DOE Facilities/Sites Listed on Docket Update \#8, Dated 11/10/93 ${ }^{1}$ (Continued)

\begin{tabular}{|c|c|c|c|}
\hline STATE & DOE FACILITY & $\begin{array}{l}\text { KNOWN OR SUSPECTED } \\
\text { PROBLEMS }\end{array}$ & CURRENT STATUS \\
\hline Florida & Pinellas Plant & $\begin{array}{l}\text { Onsite soil and groundwater } \\
\text { and offsite groundwater/ } \\
\text { chemical contamination }\end{array}$ & $\begin{array}{l}\text { Not an NPL site. } 2 \text { RFI reports approved; } 3 \text { Interim } \\
\text { Corrective Measures Plans approved; } 2 \text { Corrective Measures } \\
\text { Study reports submitted; } 1 \text { RFA report approved; classified as } \\
\text { Site Evaluation Accomplished. }\end{array}$ \\
\hline Hawaii & Kauai Test Facility & $\begin{array}{l}\text { Elevated metals in soil at the } \\
\text { Rocket Launcher Field }\end{array}$ & $\begin{array}{l}\text { Not an NPL site. Listed on Docket 2/5/93; PA Report } \\
\text { submitted 1/94; SI completed 5/94; SI Report began 6/94, to } \\
\text { be submitted FY } 95 \text {. }\end{array}$ \\
\hline Idaho & $\begin{array}{l}\text { Idaho National Engineering } \\
\text { Laboratory }\end{array}$ & $\begin{array}{l}\text { Onsite groundwater and } \\
\text { soil/chemical and radioactive } \\
\text { contamination }\end{array}$ & $\begin{array}{l}\text { NPL site. } 30 \text { No Further Action Determinations approved; } \\
1 \text { Final Action ROD (OU 7-08) signed 2/17/95; RI/FS } \\
\text { activities under way or complete at all 10 WAGs; } 4 \text { Draft } \\
\text { RI/FS Reports (2 Final Drafts) submitted; } 2 \text { Draft Final RODs } \\
\text { submitted; } 4 \text { Draft RI/FS Statements of Work (2 Final Drafts) } \\
\text { submitted; } 1 \text { Draft Final RA Work Plan submitted; } 2 \text { Draft } \\
\text { RD/RA Work Plan (1 Final Draft) submitted; } 2 \text { Removal } \\
\text { Actions completed; } 2 \text { Interim Actions completed; } 2 \text { Draft Final } \\
\text { RA Reports submitted; } 1 \text { Draft Final Remedial Design } \\
\text { submitted; } 2 \text { Draft Remedial Investigation Reports submitted; } \\
1 \text { Draft and } 1 \text { Final Proposed Plans submitted; and } 1 \text { Initial } \\
\text { Draft RD/RA Statement of Work submitted. }\end{array}$ \\
\hline \multirow[t]{2}{*}{ Illinois } & $\begin{array}{l}\text { Argonne National } \\
\text { Laboratory - East }\end{array}$ & $\begin{array}{l}\text { Onsite groundwater and } \\
\text { soil/chemical and radioactive } \\
\text { contamination }\end{array}$ & $\begin{array}{l}\text { Not an NPL site. Remedial actions expected to begin in FY } \\
95 \text { in accordance with state-approved RCRA corrective action } \\
\text { work plans. }\end{array}$ \\
\hline & $\begin{array}{l}\text { Fermi National Accelerator } \\
\text { Laboratory }\end{array}$ & $\begin{array}{l}\text { Onsite soil and } \\
\text { groundwater/chemical } \\
\text { contamination }\end{array}$ & $\begin{array}{l}\text { Not an NPL site. PA submitted to EPA Region V 11/93; } \\
\text { Preliminary risk assessment for PCB cleanup completed } \\
\text { 2/19/93; classified as Site Evaluation Accomplished. }\end{array}$ \\
\hline \multirow[t]{2}{*}{ Iowa } & Ames Laboratory & $\begin{array}{l}\text { Offsite soil/radioactive } \\
\text { contamination }\end{array}$ & $\begin{array}{l}\text { Not an NPL site. RI/FS in progress; source removal complete; } \\
\text { groundwater monitoring system planned. }\end{array}$ \\
\hline & $\begin{array}{l}\text { Hinton Hazardous Waste } \\
\text { Storage Facility (WAPA) }\end{array}$ & $\begin{array}{l}\text { Onsite soil/chemical } \\
\text { contamination }\end{array}$ & $\begin{array}{l}\text { Not an NPL site. Classified as Site Evaluation Accomplished } \\
\text { in } 2 / 5 / 93 \text { Docket (Update \#7). Soil incinerated and disposed } \\
\text { of in November 1993. Closure expected in FY } 95 \text {. }\end{array}$ \\
\hline
\end{tabular}


Table V-1. Status of All DOE Facilities/Sites Listed on Docket Update \#8, Dated 11/10/93 ${ }^{1}$ (Continued)

\begin{tabular}{|c|c|c|c|}
\hline STATE & DOE FACILITY & $\begin{array}{c}\text { KNOWN OR SUSPECTED } \\
\text { PROBLEMS }\end{array}$ & CURRENT STATUS \\
\hline Kentucky & $\begin{array}{l}\text { Paducah Gaseous Diffusion } \\
\text { Plant }\end{array}$ & $\begin{array}{l}\text { Onsite soil/chemical; } \\
\text { offsite groundwater/ } \\
\text { chemical contamination and } \\
\text { rad absorbed dose; offsite } \\
\text { fish/PCB contamination }\end{array}$ & $\begin{array}{l}\text { Listed on NPL } 5 / 31 / 94,2 \text { RI work plans for } 4 \text { WAGs, } 1 \text { RI } \\
\text { addendum, and } 1 \mathrm{FS} / \mathrm{PP} \text { submitted to regulators; and } 1 \text { interim } \\
\text { action ROD submitted and signed by EPA and concurred with } \\
\text { by state. }\end{array}$ \\
\hline \multirow[t]{2}{*}{ Louisiana } & Weeks Island (SPRO) & None known & $\begin{array}{l}\text { Not an NPL site. Determination made by EPA Region VI on } \\
9 / 16 / 91 \text { that no PA/SI required; classified as Site Evaluation } \\
\text { Accomplished prior to FY } 93 \text {. }\end{array}$ \\
\hline & West Hackberry Site (SPRO) & None known & $\begin{array}{l}\text { Not an NPL site. Determination made by EPA Region VI on } \\
9 / 16 / 91 \text { that no PA/SI required; classified as Site Evaluation } \\
\text { Accomplished in FY } 93 \text {. }\end{array}$ \\
\hline \multirow[t]{3}{*}{ Missouri } & Kansas City Plant & $\begin{array}{l}\text { Onsite soil, groundwater and } \\
\text { air/chemical contamination }\end{array}$ & $\begin{array}{l}\text { Not an NPL site. Field work completed for all } 12 \text { RFIs; } 5 \\
\text { final RFI reports, } 2 \text { RFI work plans and } 1 \text { Interim Measures } \\
\text { Work Plan approved. } 2 \text { Corrective Measures Studies } \\
\text { submitted. } 1 \text { interim remedial action and } 1 \text { final remediation } \\
\text { completed, } 2 \text { interim remediations in progress. }\end{array}$ \\
\hline & $\begin{array}{l}\text { St. Louis Site (St. Louis } \\
\text { Airport Site and Vicinity } \\
\text { Properties, and St. Louis } \\
\text { Downtown Site, Latty } \\
\text { Avenue Properties) }\end{array}$ & $\begin{array}{l}\text { Onsite soil and ground- } \\
\text { water/primarily radioactive } \\
\text { with limited chemical } \\
\text { contamination; offsite soil and } \\
\text { sediments/radioactive } \\
\text { contamination }\end{array}$ & $\begin{array}{l}\text { NPL site. Approval of FS delayed and ROD deferred for } 1 \\
\text { year. }\end{array}$ \\
\hline & $\begin{array}{l}\text { Weldon Spring Site Remedial } \\
\text { Action Project }\end{array}$ & $\begin{array}{l}\text { Onsite and offsite soil and } \\
\text { groundwater/chemical and } \\
\text { radioactive contamination }\end{array}$ & $\begin{array}{l}\text { NPL site. Quarry Residuals Work Plan and Remedial Design } \\
\text { Work Plan (Conceptual Design Report) for the Chemical Plant } \\
\text { Area completed; and demolition of the Chemical Plant Site } \\
\text { Buildings Removal Action completed. }\end{array}$ \\
\hline Montana & $\begin{array}{l}\text { Western Environmental } \\
\text { Technology Office (WETO) } \\
\text { (formerly Component } \\
\text { Development and Integration } \\
\text { Facility) }\end{array}$ & & Not an NPL site. No problems identified to date. \\
\hline
\end{tabular}


Table V-1. Status of All DOE Facilities/Sites Listed on Docket Update \#8, Dated 11/10/93 ${ }^{1}$ (Continued)

\begin{tabular}{|c|c|c|c|}
\hline STATE & DOE FACILITY & $\begin{array}{l}\text { KNOWN OR SUSPECTED } \\
\text { PROBLEMS }\end{array}$ & CURRENT STATUS \\
\hline $\begin{array}{l}\text { Montana } \\
\text { (Continued) }\end{array}$ & $\begin{array}{l}\text { Hot Springs Substation TLM } \\
\text { Complex }\end{array}$ & $\begin{array}{l}\text { Soil and groundwater } \\
\text { chemical contamination }\end{array}$ & $\begin{array}{l}\text { Not an NPL site. Montana Operations Office submitted } \\
\text { recommendation of No Further Remedial Action to EPA } \\
\text { Region VIII. }\end{array}$ \\
\hline Nebraska & Sihsc Foundry Site (WAPA) & Suspected lead contamination & $\begin{array}{l}\text { Not an NPL site. PA/SI completed; has been given "non-time- } \\
\text { critical removal action" status by EPA Region VIII. Draft } \\
\text { EE/CA submitted to EPA } 2 / 94 \text { for comment. Removal Action } \\
\text { Memorandum signed } 8 / 94 \text {. Demolition of foundry scheduled } \\
\text { for FY 95. }\end{array}$ \\
\hline \multirow[t]{3}{*}{ Nevada } & Nevada Test Site & $\begin{array}{l}\text { Onsite soil and } \\
\text { groundwater/radioactive } \\
\text { contamination }\end{array}$ & $\begin{array}{l}\text { Not an NPL site. Environmental Restoration Sites Inventory } \\
\text { initiated; continued progress on the Underground Test Area } \\
\text { Operable Unit; continued negotiation of an FFA with state. } \\
\text { One RCRA closure completed and 1 RCRA closure initiated. } \\
\text { Characterization underway for } 3 \text { additional RCRA closures. } \\
\end{array}$ \\
\hline & Tonopah Test Range & $\begin{array}{l}\text { Onsite soil/radioactive } \\
\text { contamination }\end{array}$ & $\begin{array}{l}\text { Not an NPL site. Classified as Site Evaluation Accomplished } \\
\text { prior to FY 93; several removal actions were completed in } \\
\text { FY 94; additional removal actions are planned for FY } 95 \text {. }\end{array}$ \\
\hline & Yucca Mountain Site & None known & $\begin{array}{l}\text { Not an NPL site. Listed on Docket } 2 / 5 / 93 \text {. PA to be } \\
\text { prepared. }\end{array}$ \\
\hline \multirow[t]{4}{*}{ New Jersey } & Maywood Site & $\begin{array}{l}\text { Onsite and offsite soil/ } \\
\text { radioactive and potential } \\
\text { chemical contamination; } \\
\text { approximately } 57 \text { vicinity } \\
\text { properties radioactively } \\
\text { contaminated; groundwater } \\
\text { contamination beneath the } \\
\text { pile; offsite sources }\end{array}$ & $\begin{array}{l}\text { NPL site. Final Draft FS Report issued April 1994. Proposed } \\
\text { Plan developed for public comment. }\end{array}$ \\
\hline & Middlesex Sampling Plant & $\begin{array}{l}\text { Onsite soil/radioactive } \\
\text { contamination }\end{array}$ & $\begin{array}{l}\text { Not an NPL site. Draft Site Treatment Plans and } \\
\text { Characterization Report issued. }\end{array}$ \\
\hline & New Brunswick Laboratory & $\begin{array}{l}\text { Onsite soil/radioactive } \\
\text { contamination }\end{array}$ & Not an NPL site. Remedial action planning documents issued. \\
\hline & $\begin{array}{l}\text { Princeton Plasma Physics } \\
\text { Laboratory }\end{array}$ & Onsite groundwater & Not an NPL site. Listed on Docket 2/5/93. \\
\hline
\end{tabular}


Table V-1. Status of All DOE Facilities/Sites Listed on Docket Update \#8, Dated 11/10/93 ${ }^{1}$ (Continued)

\begin{tabular}{|c|c|c|c|}
\hline STATE & DOE FACILITY & $\begin{array}{l}\text { KNOWN OR SUSPECTED } \\
\text { PROBLEMS }\end{array}$ & CURRENT STATUS \\
\hline $\begin{array}{l}\text { New Jersey } \\
\text { (Continued) }\end{array}$ & Wayne Site & $\begin{array}{l}\text { Onsite soil/radioactive and } \\
\text { potential chemical } \\
\text { contamination; offsite soil/ } \\
\text { minimal radioactive } \\
\text { contamination; groundwater } \\
\text { contamination beneath pile; } \\
\text { potential offsite sources }\end{array}$ & $\begin{array}{l}\text { NPL site. Baseline risk assessment, RI Report and FS Report } \\
\text { issued; } 1 \text { proposed plan developed; cleanup completed on all } \\
\text { remaining vicinity properties. }\end{array}$ \\
\hline \multirow[t]{7}{*}{ New Mexico } & Gasbuggy & $\begin{array}{l}\text { Casing of main monitoring } \\
\text { well defective }\end{array}$ & $\begin{array}{l}\text { Not an NPL site. Well repairs scheduled for FY 95; site } \\
\text { included in Nevada Test Site Phase I report and expected to be } \\
\text { subject to new Hazard Ranking System scoring. }\end{array}$ \\
\hline & Gnome-Coach & $\begin{array}{l}\text { Groundwater } \\
\text { contamination/radioactive } \\
\text { contamination }\end{array}$ & $\begin{array}{l}\text { Not an NPL site. Site included in Nevada Test Site Phase I } \\
\text { report and expected to be subject to new Hazard Ranking } \\
\text { System scoring. }\end{array}$ \\
\hline & $\begin{array}{l}\text { Los Alamos National } \\
\text { Laboratory }\end{array}$ & $\begin{array}{l}\text { Onsite soil/chemical and } \\
\text { radioactive contamination }\end{array}$ & $\begin{array}{l}\text { Not an NPL site. RFI work in progress; decommissioning of } \\
\text { TA-21 Buildings } 3 \text { and } 4 \text { ongoing. }\end{array}$ \\
\hline & \begin{tabular}{|l|} 
Lovelace Inhalation \\
Toxicology Research Institute
\end{tabular} & $\begin{array}{l}\text { Onsite soil/chemical and } \\
\text { radioactive contamination; } \\
\text { groundwater/chemical } \\
\text { contamination }\end{array}$ & $\begin{array}{l}\text { Not an NPL site. Classified as Site Evaluation Accomplished } \\
\text { prior to FY 93; } 5 \text { fuel oil sites cleaned up in FY 93; } 2 \text { rad } \\
\text { sites scheduled for cleanup in FY 95. }\end{array}$ \\
\hline & Ross Aviation, Inc. & $\begin{array}{l}\text { Onsite soil/chemical } \\
\text { contamination }\end{array}$ & $\begin{array}{l}\text { Not an NPL site. PA due } 6 / 12 / 93 \text {. Contaminated soil } \\
\text { removed and clean soil placed in the area. CERCLA site } \\
\text { contamination considered closed. }\end{array}$ \\
\hline & $\begin{array}{l}\text { Sandia National } \\
\text { Laboratories/New Mexico }\end{array}$ & $\begin{array}{l}\text { Onsite soil and } \\
\text { groundwater/chemical and } \\
\text { radioactive contamination }\end{array}$ & $\begin{array}{l}\text { Not an NPL site. Site-wide Hydrogeologic Characterization } \\
\text { Project Annual Report completed; seven RFI work plans } \\
\text { completed. }\end{array}$ \\
\hline & Waste Isolation Pilot Plant & None known & $\begin{array}{l}\text { Not an NPL site. Listed on Docket } 2 / 5 / 93 \text {. Compliance } \\
\text { Status Report (191) submitted to the EPA in March 1994; PA } \\
\text { submitted in August 1994; Draft Compliance Application to be } \\
\text { submitted in FY 95. }\end{array}$ \\
\hline
\end{tabular}


Table V-1. Status of All DOE Facilities/Sites Listed on Docket Update \#8, Dated 11/10/931 (Continued)

\begin{tabular}{|c|c|c|c|}
\hline STATE & DOE FACILITY & $\begin{array}{l}\text { KNOWN OR SUSPECTED } \\
\text { PROBLEMS }\end{array}$ & CURRENT STATUS \\
\hline \multirow[t]{5}{*}{ New York } & $\begin{array}{l}\text { Brookhaven National } \\
\text { Laboratory }\end{array}$ & $\begin{array}{l}\text { Groundwater and } \\
\text { soil/chemical and radioactive } \\
\text { contamination }\end{array}$ & $\begin{array}{l}\text { NPL site. Draft RI and Risk Assessment Reports for OU IV } \\
\text { submitted 5/25/94. Draft Work Plan for OU V submitted } \\
\text { 10/29/93 (and later approved). Draft Work Plan for OU III } \\
\text { submitted 6/30/94 (and later approved). Work Plan } \\
\text { preparation for OU II/VII began 8/94. Work Plan for OU VI } \\
\text { finalized 6/94. Draft Completion Report for UST removal } \\
\text { completed 8/94. Draft Engineering Evaluation/Cost Analysis } \\
\text { for Landfill Removal Action submitted 7/28/94. Draft } \\
\text { Design/Closure Report for Current Landfill caps submitted } \\
\text { 6/25/94. Draft Designs for the Cesspool Removal Action } \\
\text { submitted 8/94. Building 464 Soil Removal Action completed } \\
12 / 93 \text {. }\end{array}$ \\
\hline & Colonie Site & $\begin{array}{l}\text { Onsite soil and building } \\
\text { contamination }\end{array}$ & $\begin{array}{l}\text { Not an NPL site. Engineering Evaluation/Cost Analysis for } \\
\text { site building approved 5/93. Currently formulating site-wide } \\
\text { EE/CA for radioactive wastes. }\end{array}$ \\
\hline & $\begin{array}{l}\text { Knolls Atomic Power } \\
\text { Laboratory, Niskayuna and } \\
\text { West Milton Sites }\end{array}$ & $\begin{array}{l}\text { Minor soil and groundwater } \\
\text { contamination/chemical and } \\
\text { radioactive contamination }\end{array}$ & $\begin{array}{l}\text { Not an NPL site. Both sites classified as Site Evaluation } \\
\text { Accomplished in FY } 94 .\end{array}$ \\
\hline & Niagara Falls Storage Site & $\begin{array}{l}\text { Former radioactive } \\
\text { contamination (site } \\
\text { remediation completed 1986) }\end{array}$ & $\begin{array}{l}\text { Not an NPL site. Site remediation completed } 1986 . \\
\text { DOE/EPA/state working toward applicable long-term } \\
\text { management criteria for onsite radioactive residues. } \\
\text { Radioactive wastes disposed of in onsite disposal cell. }\end{array}$ \\
\hline & $\begin{array}{l}\text { West Valley Demonstration } \\
\text { Project }\end{array}$ & None known & $\begin{array}{l}\text { Not an NPL site. Listed on Docket } 2 / 5 / 93 \text {. Preliminary } \\
\text { Assessment submitted to EPA Region II in October } 1993 . \\
\text { Site is being investigated pursuant to a RCRA } 3008(\mathrm{~h}) \\
\text { Administrative Order of Consent signed by EPA Region II and } \\
\text { New York State Department of Environmental Conservation. }\end{array}$ \\
\hline Ohio & $\begin{array}{l}\text { Fernald Environmental } \\
\text { Management Project } \\
\text { (formerly Feed Materials } \\
\text { Production Center) }\end{array}$ & $\begin{array}{l}\text { Onsite and offsite soil and } \\
\text { groundwater/radioactive } \\
\text { contamination }\end{array}$ & $\begin{array}{l}\text { NPL site. } 6 \text { removal actions complete and } 13 \text { under way; OU } \\
1 \text { RI Report submitted } 2 / 94 \text { and approved } 8 / 94 ; \text { OU } 1 \text { FS/PP } \\
\text { submitted } 3 / 94 \text { and approved } 8 / 94 ; \text { OU } 2 \text { RI Report submitted } \\
2 / 94 ; \text { OU } 2 \text { FS/PP submitted } 8 / 94 ; \text { OU } 3 \text { ROD approved } 7 / 94 ; \\
\text { OU } 4 \text { RI Report submitted 10/93 and approved } 11 / 93 ; \text { OU } 4 \\
\text { FS/PP submitted } 12 / 93 \text { and conditionally approved } 2 / 94 ; \text { and } \\
\text { OU } 5 \text { RI Report submitted 6/94. }\end{array}$ \\
\hline
\end{tabular}


Table V-1. Status of All DOE Facilities/Sites Listed on Docket Update \#8, Dated 11/10/93 ${ }^{1}$ (Continued)

\begin{tabular}{|c|c|c|c|}
\hline STATE & DOE FACILITY & $\begin{array}{l}\text { KNOWN OR SUSPECTED } \\
\text { PROBLEMS }\end{array}$ & CURRENT STATUS \\
\hline \multirow[t]{2}{*}{$\begin{array}{l}\text { Ohio } \\
\text { (Continued) }\end{array}$} & Mound Plant & \begin{tabular}{|l|} 
Onsite and offsite \\
soil/radioactive contamination; \\
onsite and offsite \\
groundwater/chemical and \\
radioactive contamination
\end{tabular} & $\begin{array}{l}\text { NPL site. The OU } 2 \text { RI Work Plan and Sampling and } \\
\text { Analysis Plan were completed. The OU } 5 \text { RI Work Plan was } \\
\text { finalized } 12 / 93 \text {. Verification of soil sites cleaned under the } \\
\text { Mound decommissioning program continued at OU } 6 \text {. } \\
\text { Assessment activities continue at OU } 9 \text {. Three removal } \\
\text { actions were initiated. }\end{array}$ \\
\hline & $\begin{array}{l}\text { Portsmouth } \\
\text { Uranium Enrichment } \\
\text { Complex }\end{array}$ & $\begin{array}{l}\text { Onsite soil and ground- } \\
\text { water/chemical and radioactive } \\
\text { contamination }\end{array}$ & $\begin{array}{l}\text { Not an NPL site. No CERCLA activities conducted during } \\
\text { FY 94. Portsmouth currently involved with RCRA corrective } \\
\text { action activities. }\end{array}$ \\
\hline Oklahoma & $\begin{array}{l}\text { National Institute for } \\
\text { Petroleum and Energy } \\
\text { Research }\end{array}$ & $\begin{array}{l}\text { Onsite soil/chemical } \\
\text { contamination }\end{array}$ & $\begin{array}{l}\text { Not an NPL site. Listed on Docket } 2 / 5 / 93 \text {. Submitted } \\
\text { Preliminary Assessment on } 08 / 01 / 94 \text {. The Hazard Ranking } \\
\text { Score was below } 28.5(14) \text {; thus, no further actions are } \\
\text { planned. EPA has not responded to the PA. }\end{array}$ \\
\hline \multirow[t]{6}{*}{ Oregon } & $\begin{array}{l}\text { Alvey Maintenance } \\
\text { Headquarters (BPA) }\end{array}$ & $\begin{array}{l}\text { Onsite soil/chemical } \\
\text { contamination }\end{array}$ & $\begin{array}{l}\text { Not an NPL site. Site characterized as No Further Remedial } \\
\text { Action. }\end{array}$ \\
\hline & Bake Oven Substation (BPA) & Potential PCB contamination & $\begin{array}{l}\text { Not an NPL site. Listed on Docket } 2 / 5 / 93 \text {; PCB cleanup } \\
\text { completed; final draft report sent to EPA Region X for review } \\
\text { and comment. }\end{array}$ \\
\hline & $\begin{array}{l}\text { Celilo Converter Station } \\
\text { (BPA) }\end{array}$ & $\begin{array}{l}\text { Onsite soil/chemical } \\
\text { contamination }\end{array}$ & $\begin{array}{l}\text { Not an NPL site. Listed on Docket 2/5/93. PA expected to } \\
\text { be submitted FY } 95 \text {. }\end{array}$ \\
\hline & Oregon City (BPA) & See Ostrander Substation & $\begin{array}{l}\text { Not an NPL site. EPA has been notified that "Ostrander } \\
\text { Substation" is the correct name for this site. }\end{array}$ \\
\hline & Ostrander Substation (BPA) & $\begin{array}{l}\text { Onsite chemical } \\
\text { contamination, no } \\
\text { contamination of media }\end{array}$ & $\begin{array}{l}\text { Not an NPL site. Listed on Docket 2/5/93; PA submitted to } \\
\text { EPA Region X 10/93. Site characterized as No Further } \\
\text { Remedial Action in FY } 94 \text {. }\end{array}$ \\
\hline & Troutdale Substation (BPA) & $\begin{array}{l}\text { Onsite soil/chemical } \\
\text { contamination }\end{array}$ & $\begin{array}{l}\text { Not an NPL site. Site characterized as No Further Remedial } \\
\text { Action. }\end{array}$ \\
\hline Pennsylvania & $\begin{array}{l}\text { Bettis Atomic Power } \\
\text { Laboratory, West Mifflin }\end{array}$ & $\begin{array}{l}\text { Minor soil and groundwater } \\
\text { contamination/chemical and } \\
\text { radioactive contamination }\end{array}$ & $\begin{array}{l}\text { Not an NPL site. Classified as Site Evaluation Accomplished } \\
\text { prior to FY 90; no further EPA action required. }\end{array}$ \\
\hline
\end{tabular}


Table V-1. Status of All DOE Facilities/Sites Listed on Docket Update \#8, Dated 11/10/93 ${ }^{1}$ (Continued)

\begin{tabular}{|c|c|c|c|}
\hline STATE & DOE FACILITY & $\begin{array}{l}\text { KNOWN OR SUSPECTED } \\
\text { PROBLEMS }\end{array}$ & CURRENT STATUS \\
\hline $\begin{array}{l}\text { Pennsylvania } \\
\text { (Continued) }\end{array}$ & $\begin{array}{l}\text { Pittsburgh Energy } \\
\text { Technology Center }\end{array}$ & $\begin{array}{l}\text { Onsite soil and groundwater } \\
\text { contamination }\end{array}$ & $\begin{array}{l}\text { Not an NPL site. Installation of groundwater monitoring } \\
\text { network completed } 11 / 93 \text {. Primary Site Sampling and } \\
\text { Analysis Investigation completed. Groundwater monitoring } \\
\text { scheduled for FY } 95 \text {. Health and Ecological Risk Assessment } \\
\text { in progress. Old Synthane Area scheduled for investigation } \\
\text { for FY 95. }\end{array}$ \\
\hline Puerto Rico & \begin{tabular}{|l|} 
Center for Energy and \\
Environmental Research \\
\end{tabular} & $\begin{array}{l}\text { Onsite soil/radioactive } \\
\text { contamination }\end{array}$ & $\begin{array}{l}\text { Not an NPL site. PA submitted } 5 / 16 / 88 \text {; the } \\
\text { decommissioning activities are complete. }\end{array}$ \\
\hline South Carolina & Savannah River Site & $\begin{array}{l}\text { Onsite groundwater, soil and } \\
\text { air/chemical and radioactive } \\
\text { contamination }\end{array}$ & $\begin{array}{l}\text { NPL site. } 2 \text { RFI/RI plans submitted; } 3 \text { interim remedial } \\
\text { proposed plans submitted; } 4 \text { remedial proposed plans } \\
\text { submitted; } 2 \text { final remedial RODs signed; } 24 \text { site evaluation } \\
\text { reports submitted; } 6 \text { waste removal actions completed; } \\
2 \text { baseline risk assessments submitted; } 4 \text { revised RCRA } \\
\text { closure plans submitted; F\&H Area Groundwater OU } \\
\text { Proposed Plan submitted; 1 Corrective Action Plan submitted; } \\
7 \text { Remedial Actions completed; and } 13 \text { Interim Actions } \\
\text { completed. }\end{array}$ \\
\hline South Dakota & $\begin{array}{l}\text { Watertown Maintenance } \\
\text { Facility (WAPA) }\end{array}$ & $\begin{array}{l}\text { Onsite potential soil/chemical } \\
\text { contamination }\end{array}$ & $\begin{array}{l}\text { Not an NPL site. PA submitted 5/90, SI submitted 10/91; } \\
\text { awaiting response from EPA Region VIII. }\end{array}$ \\
\hline \multirow[t]{3}{*}{ Tennessee } & $\begin{array}{l}\text { Oak Ridge Reservation; } \\
\text { K-25 Site (Oak Ridge } \\
\text { Gaseous Diffusion Plant) }\end{array}$ & $\begin{array}{l}\text { Onsite groundwater, soil and } \\
\text { surface water/ chemical and } \\
\text { radioactive contamination }\end{array}$ & $\begin{array}{l}\text { NPL site. } 1 \text { Draft RI Report submitted and } 1 \text { Phase } 1 \text { Interim } \\
\text { Action completed. }\end{array}$ \\
\hline & $\begin{array}{l}\text { Oak Ridge Reservation; } \\
\text { Oak Ridge Associated } \\
\text { Universities }\end{array}$ & $\begin{array}{l}\text { Onsite groundwater, soil and } \\
\text { surface water/ chemical and } \\
\text { radioactive contamination }\end{array}$ & NPL site. 1 RI Work Plan/SI Report submitted. \\
\hline & $\begin{array}{l}\text { Oak Ridge Reservation; } \\
\text { Oak Ridge National } \\
\text { Laboratory }\end{array}$ & $\begin{array}{l}\text { Onsite groundwater, soil and } \\
\text { surface water/ chemical and } \\
\text { radioactive contamination }\end{array}$ & $\begin{array}{l}\text { NPL site. 1 RI/FS Report submitted; } 1 \text { Site Characterization } \\
\text { Work Plan submitted; } 2 \text { Interim RODs approved; } 1 \\
\text { Engineering Evaluation/Cost Analysis submitted and } \\
\text { approved; } 3 \text { Treatability Study Work Plans submitted; } \\
2 \text { Proposed Plans submitted; } 2 \text { Interim ROD cleanup activities } \\
\text { completed and Post-Construction Reports submitted; } \\
1 \text { Removal Action Design completed. }\end{array}$ \\
\hline
\end{tabular}


Table V-1. Status of All DOE Facilities/Sites Listed on Docket Update \#8, Dated 11/10/93 ${ }^{1}$ (Continued)

\begin{tabular}{|c|c|c|c|}
\hline STATE & DOE FACILITY & $\begin{array}{l}\text { KNOWN OR SUSPECTED } \\
\text { PROBLEMS }\end{array}$ & CURRENT STATUS \\
\hline \multirow[t]{2}{*}{$\begin{array}{l}\text { Tennessee } \\
\text { (Continued) }\end{array}$} & $\begin{array}{l}\text { Oak Ridge Reservation } \\
\text { (offsite) }\end{array}$ & $\begin{array}{l}\text { Offsite soil and surface } \\
\text { water/chemical and radioactive } \\
\text { contamination, mercury and } \\
\text { other heavy metals, PCBs, and } \\
\text { traces of uranium in } \\
\text { floodplain, soils and sediment } \\
\end{array}$ & $\begin{array}{l}\text { NPL site. Submittal and approval of plan to separate Clinch } \\
\text { River and Watts Bar OU into two separate remedial actions to } \\
\text { streamline the remediation process; } 3 \text { removal actions } \\
\text { completed; } 2 \text { RI/FS Reports submitted; and one Proposed } \\
\text { Plan submitted. }\end{array}$ \\
\hline & $\begin{array}{l}\text { Oak Ridge Reservation; } \\
\text { Y-12 Plant }\end{array}$ & $\begin{array}{l}\text { Onsite groundwater, soil and } \\
\text { surface water/ chemical and } \\
\text { radioactive contamination }\end{array}$ & $\begin{array}{l}\text { NPL site. Submittal of } 3 \text { RI reports, } 2 \text { FS Reports, } 1 \\
\text { Proposed Plan, } 1 \text { ROD, and } 2 \text { Post-Construction Reports } \\
\text { submitted; } 3 \text { RCRA closures completed; } 1 \text { Interim Removal } \\
\text { completed. }\end{array}$ \\
\hline \multirow[t]{2}{*}{ Texas } & Big Hill Site (SPRO) & $\begin{array}{l}\text { Onsite soil/chemical } \\
\text { contamination }\end{array}$ & $\begin{array}{l}\text { Not an NPL site. Determination made by EPA Region VI, on } \\
9 / 16 / 91 \text { that no PA/SI required; site characterized as No } \\
\text { Further Remedial Action. }\end{array}$ \\
\hline & Pantex Plant & $\begin{array}{l}\text { Onsite soil and } \\
\text { groundwater/chemical and } \\
\text { radioactive contamination }\end{array}$ & $\begin{array}{l}\text { Listed on NPL 5/31/94. 14 RFI Reports submitted and } \\
\text { approved. }\end{array}$ \\
\hline Utah & $\begin{array}{l}\text { Monticello Mill Site and } \\
\text { Monticello Vicinity } \\
\text { Properties }\end{array}$ & $\begin{array}{l}\text { Onsite and offsite } \\
\text { groundwater, soil and surface } \\
\text { water/chemical and radioactive } \\
\text { contamination }\end{array}$ & $\begin{array}{l}\text { NPL site. Remedial actions completed on } 62 \text { more of the } 410 \\
\text { Vicinity Properties in FY } 94 \text { ( } 305 \text { total); continuing remedial } \\
\text { design and remedial action for other Vicinity Properties and } \\
\text { the Mill Site; construction of surface water control structures } \\
\text { begun and construction of staging/decon area including a } \\
\text { runoff retention pond completed at OU 1; remedial action } \\
\text { begun on } 4 \text { peripheral properties and completed on } 3 \\
\text { properties in OU 2; baseline surface water and groundwater } \\
\text { sampling for OU } 3 \text { completed and a report prepared; Draft } \\
\text { Final Work Plan for OU } 3 \text { RI/FS work submitted. }\end{array}$ \\
\hline \multirow[t]{3}{*}{ Washington } & $\begin{array}{l}\text { Columbia Basin Project AEC } \\
\text { Zone 2,4-D Site }\end{array}$ & $\begin{array}{l}\text { Onsite soil/chemical } \\
\text { contamination }\end{array}$ & Not an NPL site. Deletion from Docket requested. \\
\hline & Columbia Substation (BPA) & $\begin{array}{l}\text { Onsite soil/chemical } \\
\text { contamination }\end{array}$ & $\begin{array}{l}\text { Not an NPL site. Site characterized as No Further Remedial } \\
\text { Action. }\end{array}$ \\
\hline & Cosmopolis (BPA) & Potential PCB contamination & $\begin{array}{l}\text { Not an NPL site. Listed on Docket } 2 / 5 / 93 \text {; cleanup of } \\
\text { reportable spill performed prior to FY 93; EPA Region X not } \\
\text { requiring submission of a PA at this time. }\end{array}$ \\
\hline
\end{tabular}


Table V-1. Status of All DOE Facilities/Sites Listed on Docket Update \#8, Dated 11/10/93 ${ }^{1}$ (Continued)

\begin{tabular}{|c|c|c|c|}
\hline STATE & DOE FACILITY & $\begin{array}{l}\text { KNOWN OR SUSPECTED } \\
\text { PROBLEMS }\end{array}$ & CURRENT STATUS \\
\hline \multirow[t]{10}{*}{$\begin{array}{l}\text { Washington } \\
\text { (Continued) }\end{array}$} & Covington Substation (BPA) & $\begin{array}{l}\begin{array}{l}\text { Onsite soil/chemical } \\
\text { contamination }\end{array} \\
\end{array}$ & $\begin{array}{l}\text { Not an NPL site. SI completed and SI report submitted to } \\
\text { EPA Region X FY } 94 \text {. }\end{array}$ \\
\hline & $\begin{array}{l}\text { G.H. Bell Substation and } \\
\text { Maintenance Complex (BPA) } \\
\end{array}$ & $\begin{array}{l}\text { Onsite soil/chemical } \\
\text { contamination }\end{array}$ & $\begin{array}{l}\text { Not an NPL site. Site characterized as No Further Remedial } \\
\text { Action Planned. }\end{array}$ \\
\hline & $\begin{array}{l}\text { Hanford Site (Areas 100, } \\
200,300, \text { and } 1100)\end{array}$ & $\begin{array}{l}\text { Onsite groundwater and } \\
\text { soil/chemical and radioactive } \\
\text { contamination }\end{array}$ & $\begin{array}{l}\text { NPL site. } 3 \text { Work Plans, } 3 \text { Proposed Plans, } 3 \text { Focused FS } \\
\text { Reports, } 1 \text { Phase } 3 \text { FS Report, } 1 \text { RI Report, and } 6 \text { limited } \\
\text { Field Investigation Reports were submitted. } 2 \text { Treatability } \\
\text { tests completed. }\end{array}$ \\
\hline & Lapine (BPA) & $\begin{array}{l}\text { Onsite soil/chemical } \\
\text { contamination }\end{array}$ & $\begin{array}{l}\text { Not an NPL site. Based on review of existing documentation, } \\
\text { EPA Region X has determined that Docket listing is not } \\
\text { warranted and will propose site for deletion from Docket. } \\
\text { (Note: The FY } 92 \text { report to Congress erroneously indicated } \\
\text { that a PA was submitted. No PA has been submitted for this } \\
\text { site.) }\end{array}$ \\
\hline & $\begin{array}{l}\text { Maple Valley Substation } \\
\text { (BPA) }\end{array}$ & $\begin{array}{l}\text { Onsite soil/chemical } \\
\text { contamination }\end{array}$ & $\begin{array}{l}\text { Not an NPL site. EPA Region X is not requiring a PA at this } \\
\text { time. (Note: The FY } 92 \text { report to Congress erroneously } \\
\text { indicated that a PA was submitted. No PA has been submitted } \\
\text { for this site.) }\end{array}$ \\
\hline & Midway Substation (BPA) & $\begin{array}{l}\text { Onsite soil/chemical } \\
\text { contamination }\end{array}$ & $\begin{array}{l}\text { Not an NPL site. Site characterized as No Further Remedial } \\
\text { Action. }\end{array}$ \\
\hline & Monroe (BPA) & Onsite chemical contamination & $\begin{array}{l}\text { Not an NPL site. Listed on Docket } 2 / 5 / 93 \text {; EPA not requiring } \\
\text { PA at this time. }\end{array}$ \\
\hline & Olympia Substation (BPA) & $\begin{array}{l}\text { Onsite soil/chemical } \\
\text { contamination }\end{array}$ & $\begin{array}{l}\text { Not an NPL site. SI completed and sent to EPA Region X } \\
\text { FY } 94 \text {. }\end{array}$ \\
\hline & Port Angeles (BPA) & Onsite chemical contamination & $\begin{array}{l}\text { Not an NPL site. Listed on Docket } 2 / 5 / 93 \text {; cleanup of } \\
\text { reportable spill performed prior to FY 93; PA expected to be } \\
\text { submitted FY } 95 \text {. }\end{array}$ \\
\hline & Ross Complex (BPA) & $\begin{array}{l}\text { Onsite soil and potential } \\
\text { groundwater/chemical } \\
\text { contamination }\end{array}$ & $\begin{array}{l}\text { NPL site. Capacitor Test Lab completed, cap installation over } \\
\text { fog chamber dump near completion, and contaminated soil } \\
\text { from Wood Pole Storage Yard excavated for treatment in } \\
\text { FY 94. }\end{array}$ \\
\hline
\end{tabular}


Table V-1. Status of All DOE Facilities/Sites Listed on Docket Update \#8, Dated 11/10/93 ${ }^{1}$ (Continued)

\begin{tabular}{|c|l|l|l|}
\hline \multicolumn{1}{|c|}{ STATE } & \multicolumn{1}{|c|}{ DOE FACILITY } & $\begin{array}{l}\text { KNOWN OR SUSPECTED } \\
\text { PROBLEMS }\end{array}$ & CURRENT STATUS \\
\hline $\begin{array}{l}\text { Washington } \\
\text { (Continued) }\end{array}$ & Snohomish Substation (BPA) & $\begin{array}{l}\text { Onsite soil/chemical } \\
\text { contamination }\end{array}$ & Not an NPL site. SI conducted during FY 94. \\
\cline { 2 - 4 } & Snow King Substation (BPA) & No Information & $\begin{array}{l}\text { Not an NPL site. EPA Region X is not requiring PA at this } \\
\text { time. }\end{array}$ \\
\hline West Virginia & $\begin{array}{l}\text { Morgantown Energy } \\
\text { Technology Center }\end{array}$ & $\begin{array}{l}\text { Onsite soil and potential } \\
\text { groundwater/chemical } \\
\text { contamination }\end{array}$ & $\begin{array}{l}\text { Not an NPL site. PA/SI review by EPA Region III in } \\
\text { progress responding to requests (via EPA Deficiency } \\
\text { Checklist) for additional data preparatory to HRS scoring. }\end{array}$ \\
\hline Wyoming & Casper Field Branch (WAPA) & None known & Not an NPL site. Classified as Site Evaluation Accomplished. \\
\cline { 2 - 4 } & Hoe Creek & $\begin{array}{l}\text { Onsite groundwater/chemical } \\
\text { contamination }\end{array}$ & $\begin{array}{l}\text { Not an NPL site. Classified as Site Evaluation Accomplished; } \\
\text { interim pump and treat action completed; site characterization } \\
\text { completed; and cleanup alternatives study completed and } \\
\text { report submitted to state for review. }\end{array}$ \\
\hline \hline
\end{tabular}

Acronyms and abbreviations used in this table are found in Appendix A.

2 This facility is owned and operated by the U.S. Department of the Interior's Bureau of Land Reclamation. It was erroneously identified on the docket as a DOE facility. The facility is included in this report to avoid confusion. 


\section{APPENDICES}

\section{APPENDIX A - LIST OF ACRONYMS AND ABBREVIATIONS}

APPENDIX B - LISTING OF FACILITIES 


\section{APPENDIX A}

List of Acronyms and Abbreviations

\begin{tabular}{|c|c|}
\hline ALE & Arid Lands Ecology \\
\hline ANL & Argonne National Laboratory \\
\hline ARA & Auxiliary Reactor Area \\
\hline BORAX & Boiling Water Reactor Experiment Reactor \\
\hline BPA & Bonneville Power Administration \\
\hline CDPHE & Colorado Department of Public Health and Environment \\
\hline CERCLA & Comprehensive Environmental Response, Compensation, and Liability Act \\
\hline COCA & Consent Order and Compliance Agreement \\
\hline DOE & U.S. Department of Energy \\
\hline DOI & U.S. Department of the Interior \\
\hline $\mathrm{EH}$ & Office of Environment, Safety and Health \\
\hline EM & Office of Environmental Management \\
\hline EPA & U.S. Environmental Protection Agency \\
\hline ERA & Expedited Response Action \\
\hline FEMP & Fernald Environmental Management Project \\
\hline FFA & Federal Facility Agreement \\
\hline FFCA & Federal Facility Compliance Agreement \\
\hline FS & Feasibility Study \\
\hline FS/PP & Feasibility Study/Proposed Plan \\
\hline $\mathrm{ft}$ & feet \\
\hline FUSRAP & Formerly Utilized Sites Remedial Action Program \\
\hline FY & Fiscal Year \\
\hline GSA & General Services Area \\
\hline IAG & Interagency Agreement \\
\hline $\mathrm{IM} / \mathrm{IRA}$ & Interim Measure/Interim Remedial Action \\
\hline INEL & Idaho National Engineering Laboratory \\
\hline IRA & Interim Remedial Action \\
\hline $\mathbf{k V}$ & kilovolt \\
\hline LANL & Los Alamos National Laboratory \\
\hline LBL & Lawrence Berkeley Laboratory \\
\hline lbs & pounds \\
\hline LEHR & Laboratory for Energy - Health Research \\
\hline LLNL & Lawrence Livermore National Laboratory \\
\hline MOA & Memorandum of Agreement \\
\hline MOU & Memorandum of Understanding \\
\hline MTCA & Model Toxics Control Act \\
\hline NCP & National Contingency Plan \\
\hline
\end{tabular}




\section{APPENDIX A}

List of Acronyms and Abbreviations (Continued)

\begin{tabular}{|c|c|}
\hline NEPA & National Environmental Policy Act \\
\hline NPDES & National Pollutant Discharge Elimination System \\
\hline NPL & National Priorities List \\
\hline NRF & Naval Reactors Facility \\
\hline ORAU & Oak Ridge Associated Universities \\
\hline ORNL & Oak Ridge National Laboratory \\
\hline ORR & Oak Ridge Reservation \\
\hline OU & Operable Unit \\
\hline PA & Preliminary Assessment \\
\hline $\mathrm{PA} / \mathrm{SI}$ & Preliminary Assessment/Site Investigation \\
\hline PCB & Polychlorinated Biphenyl \\
\hline PEA & Preliminary Environmental Assessment \\
\hline PP & Proposed Plan \\
\hline RA & Remedial Action \\
\hline RCRA & Resource Conservation and Recovery Act \\
\hline $\mathrm{R} \& \mathrm{D}$ & Research and Development \\
\hline $\mathrm{RD} / \mathrm{RA}$ & Remedial Design/Remedial Action \\
\hline RDDT\&E & Research, Development, Demonstration, Testing and Evaluation \\
\hline RFA & RCRA Facility Assessment \\
\hline RFCA & Rocky Flats Cleanup Agreement \\
\hline RFETS & Rocky Flats Environmental Technology Site \\
\hline RFI & RCRA Facility Investigation \\
\hline RFI/RI & RCRA Facility Investigation/Remedial Investigation \\
\hline RI & Remedial Investigation \\
\hline $\mathrm{RI} / \mathrm{FS}$ & Remedial Investigation/Feasibility Study \\
\hline ROD & Record of Decision \\
\hline RWQCB & Regional Water Quality Control Board \\
\hline SARA & Superfund Amendments and Reauthorization Act \\
\hline SCDHEC & South Carolina Department of Health and Environmental Control \\
\hline SI & Site Investigation \\
\hline SITE & Superfund Innovative Technology Evaluation \\
\hline SL-1 & Stationary Low Power Reactor-1 \\
\hline SPRO & Strategic Petroleum Reserve Office \\
\hline SRS & Savannah River Site \\
\hline SWMU & Solid Waste Management Unit \\
\hline SWRI & Site Wide Remedial Investigation \\
\hline TSCA & Toxic Substances Control Act \\
\hline
\end{tabular}




\section{APPENDIX A}

List of Acronyms and Abbreviations (Continued)

$\begin{array}{ll}\text { UCD } & \text { University of California, Davis } \\ \text { USEC } & \text { U.S. Enrichment Corporation } \\ \text { VOC } & \text { Volatile Organic Compound } \\ \text { WAG } & \text { Waste Area Group } \\ \text { WAPA } & \text { Western Area Power Administration }\end{array}$


This Page Intentionally Left Blank. 


\section{APPENDIX B}

Listing of Facilities

\section{Facility Name}

Page Number

Alvey Maintenance Headquarters (BPA) $\ldots \ldots \ldots \ldots \ldots \ldots \ldots \ldots \ldots \ldots \ldots \ldots \ldots \ldots$

Ames Laboratory . . . . . . . . . . . . . . . . . . . . . . . . . . . . . V-4

Anvil Paints Facility, Naval Oil Shale Reserve No. $3 \ldots \ldots \ldots \ldots \ldots \ldots \ldots \ldots \ldots \ldots$. . . . . . .

Argonne National Laboratory - East . . . . . . . . . . . . . . . . . . . . . . . V-4

Bake Oven Substation (BPA) . . . . . . . . . . . . . . . . . . . . . . . . . . . . V-9

Bettis Atomic Power Laboratory, West Mifflin . . . . . . . . . . . . . . . . . . . . V-9

Big Hill Site (SPRO) . . . . . . . . . . . . . . . . . . . . . . . . . . . . V-11

Brookhaven National Laboratory $\ldots \ldots \ldots \ldots \ldots$. . . . . . . . . . . . . III-29-III-30; V-8

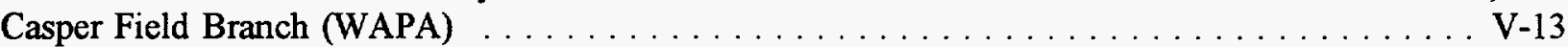

Celilo Converter Station $(\mathrm{BPA}) \quad \ldots \ldots \ldots \ldots \ldots \ldots \ldots \ldots \ldots \ldots \ldots \ldots \ldots \ldots \ldots$

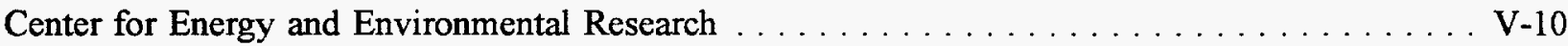

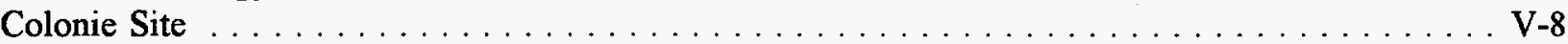

Columbia Basin Project AEC Zone $2,4-\mathrm{D}$ Site $\ldots \ldots \ldots \ldots \ldots \ldots \ldots \ldots \ldots \ldots \ldots$ V-11

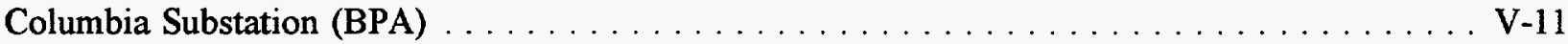

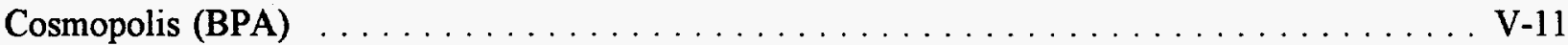

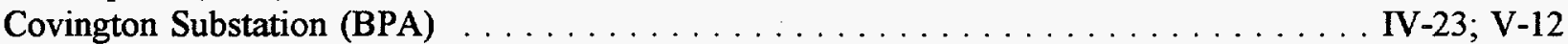

Fermi National Accelerator Laboratory . . . . . . . . . . . . . . . . . . . . . . . . V-4

Fernald Environmental Management Project . . . . . . . . . . . . . III-31-III-37; V-8

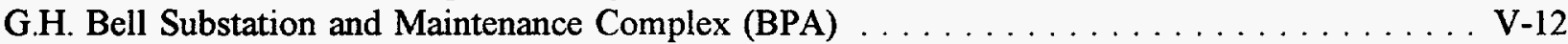

Gasbuggy . . . . . . . . . . . . . . . . . . . . . . . . . . . . . V-7

Gnome-Coach . . . . . . . . . . . . . . . . . . . . . . . . . . . . . . . V-7

Grand Junction Projects Office Remedial Action Project $\ldots \ldots \ldots \ldots \ldots \ldots \ldots \ldots \ldots \ldots \ldots$ V-3

Hanford Site $\ldots \ldots \ldots \ldots \ldots \ldots \ldots \ldots \ldots \ldots \ldots \ldots \ldots \ldots \ldots \ldots \ldots$ III-53-III-56; V-12

Hinton Hazardous Waste Storage Facility (WAPA) . . . . . . . . . . . . . . . IV-11; V-4

Hoe Creek . . . . . . . . . . . . . . . . . . . . . . . . . . . . . IV-27; V-13

Hot Springs Substation TLM Complex . . . . . . . . . . . . . . . . . . . . . V-6

Idaho National Engineering Laboratory . . . . . . . . . . . . . . . . . III-15-III-18; V-4

Kansas City Plant . . . . . . . . . . . . . . . . . . . . . IV-13-IV-14; V-5

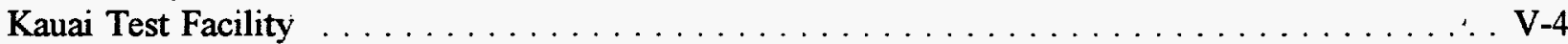

Knolls Atomic Power Laboratory, Niskayuna and West Milton Sites . . . . . . . . . . . . V-8

Knolls Atomic Power Laboratory, Windsor Site . . . . . . . . . . . . . . . . . . . . . . . . V-3

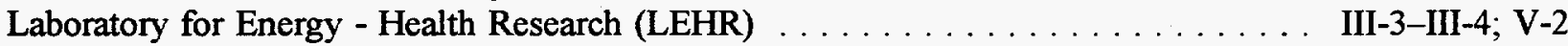

Lapine (BPA) . . . . . . . . . . . . . . . . . . . . . . . . . . . . . . . . V-12

Lawrence Berkeley Laboratory . . . . . . . . . . . . . . . . . . . . . . IV-3; V-2

Lawrence Livermore National Laboratory - Main Site . . . . . . . . . . . . . . . III-5-III-6; V-2

Lawrence Livermore National Laboratory - Site $300 \ldots \ldots \ldots \ldots$. . . . . . . . . III-7-III-8; V-2

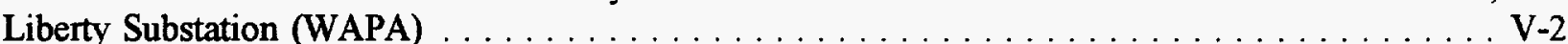

Los Alamos National Laboratory . . . . . . . . . . . . . . . . . . . . . IV-17; V-7

Lovelace Inhalation Toxicology Research Institute . . . . . . . . . . . . . . . . . V-7

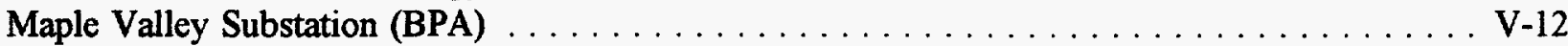

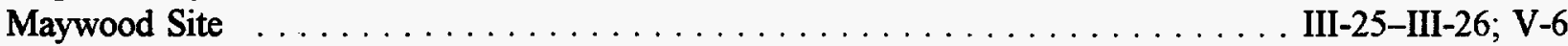

Middlesex Sampling Plant $\ldots \ldots \ldots \ldots \ldots \ldots \ldots \ldots \ldots \ldots \ldots \ldots \ldots \ldots \ldots$

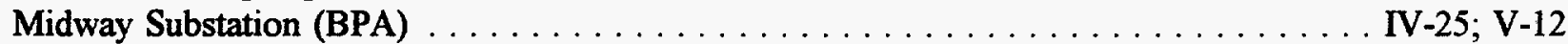




\section{APPENDIX B}

\section{Listing of Facilities (Continued)}

Facility Name

Page Number

Monroe (BPA)

$\mathrm{V}-12$

Monticello Mill Site and Monticello Vicinity Properties

III-51-III-52; V-11

Montrose Power Operations Center (WAPA)

$\mathrm{V}-3$

Morgantown Energy Technology Center

$\mathrm{V}-13$

Mound Plant

National Institute for Petroleum and Energy Research

III-39-III-40; V-9

National Renewable Energy Laboratory

$\mathrm{V}-9$

Naval Petroleum Reserve Nos. 1 and 2

$\mathrm{V}-3$

Nevada Test Site

$\mathrm{V}-2$

New Brunswick Laboratory

Niagara Falls Storage Site

Oak Ridge Reservation

IV-15-IV-16; V-6

Olympia Substation (BPA)

$\mathrm{V}-8$

Oregon City (BPA)

$\mathrm{III}-45-\mathrm{III}-48 ; \mathrm{V}-10 ; \mathrm{V}-11$
$\ldots \ldots \mathrm{V}-12$

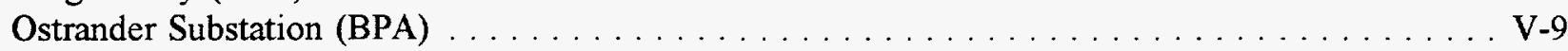

Oxnard Facility $V-2$

Paducah Gaseous Diffusion Plant

III-19-III-20; V-5

Pantex Plant

III-49-III-50; V-11

Parker Dam Switchyard

$\mathrm{V}-2$

Pinellas Plant

IV-9-IV-10; V-4

Pittsburgh Energy Technology Center

V-10

Port Angeles (BPA)

V-12

Portsmouth Uranium Enrichment Complex

IV-21-IV-22; V-9

Princeton Plasma Physics Laboratory

$\ldots \ldots . . . \mathrm{V}-6$

Rocky Flats Environmental Technology Site

III-9-III-14; V-3

Ross Aviation, Inc.

$\mathrm{V}-7$

Ross Complex (BPA)

III-57-III-58; V-12

Sandia National Laboratories/Califomia

IV-5-IV-6; V-2

Sandia National Laboratories/New Mexico

IV-19-IV-20; V-7

Santa Susana Field Laboratories

$\mathrm{V}-3$

Savannah River Site

III-41-III-43; V-10

Sihsc Foundry Site (WAPA)

$\mathrm{V}-6$

Snohomish Substation (BPA)

$\mathrm{V}-13$

Snow King Substation (BPA)

$\mathrm{V}-13$

St. Louis Site

III-21-III-22; V-5

Stanford Linear Accelerator Center

$\mathrm{V}-3$

Tonopah Test Range

$\mathrm{V}-6$

Tracy Pump and Substation (WAPA)

IV-7; V-3

Troutdale Substation (BPA)

Waste Isolation Pilot Plant

Watertown Maintenance Facility (WAPA)

$\mathrm{V}-10$

Wayne Site

III-27-III-28; V-7

Weeks Island (SPRO)

$\mathrm{V}-5$ 


\section{APPENDIX B}

Listing of Facilities (Continued)

\section{Facility Name}

Page Number

Weldon Spring Site Remedial Action Project III-23-III-24; V-5

West Hackberry Site (SPRO) $\mathrm{V}-5$

West Valley Demonstration Project $V-8$

Western Environmental Technology Office $\mathrm{V}-5$

Yucca Mountain Site V-6 
This Page Intentionally Left Blank. 